\title{
BENCH-SCALE STEAM REFORMING OF ACTUAL TANK 48H WASTE
}

P. R. Burket

W. E. Daniel

C. A. Nash

C. M. Jantzen

M. R. Williams

September 2008

Process Science \& Engineering Section

Savannah River National Laboratory

Aiken, SC 29808

Prepared for the U.S. Department of Energy Under Contract Number DEAC09-08SR22470

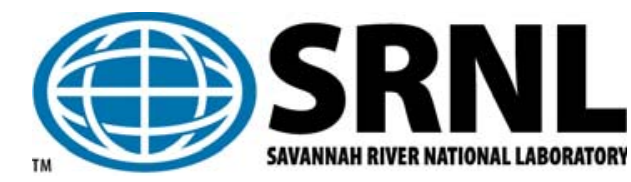


SRNS-STI-2008-00105

Revision 0, 9/25/08

\section{DISCLAIMER}

This work was prepared under an agreement with and funded by the U.S. Government. Neither the U. S. Government or its employees, nor any of its contractors, subcontractors or their employees, makes any express or implied: 1. warranty or assumes any legal liability for the accuracy, completeness, or for the use or results of such use of any information, product, or process disclosed;

or 2. representation that such use or results of such use would not infringe privately owned rights; or 3. endorsement or recommendation of any specifically identified commercial product, process, or service. Any views and opinions of authors expressed in this work do not necessarily state or reflect those of the United States Government, or its contractors, or subcontractors

\section{Printed in the United States of America \\ Prepared For U.S. Department of Energy}


Key Words:

Tank $48 \mathrm{H}$

Steam Reforming

Waste form

Retention: Permanent

\section{BENCH-SCALE STEAM REFORMING OF ACTUAL TANK 48H WASTE}

P. R. Burket

W. E. Daniel

C. A. Nash

C. M. Jantzen

M. R. Williams

September 2008

Process Science \& Engineering Section Savannah River National Laboratory

Aiken, SC 29808

Prepared for the U.S. Department of Energy Under Contract Number DEAC09-08SR22470

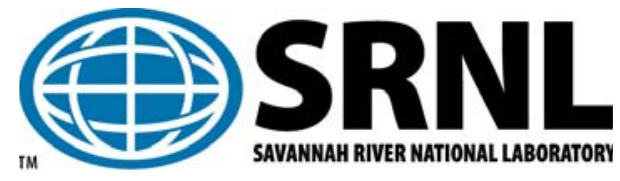


SRNS-STI-2008-00105

Revision 0, 9/25/08

\section{REVIEWS AND APPROVALS}




\section{EXECUTIVE SUMMARY}

Fluidized Bed Steam Reforming (FBSR) has been demonstrated to be a viable technology to remove $>99 \%$ of the organics from Tank $48 \mathrm{H}$ simulant, to remove $>99 \%$ of the nitrate/nitrite from Tank $48 \mathrm{H}$ simulant, and to form a solid product that is primarily carbonate based. The technology was demonstrated in October of 2006 in the Engineering Scale Test Demonstration Fluidized Bed Steam Reformer ${ }^{1}$ (ESTD FBSR) at the Hazen Research Inc. (HRI) facility in Golden, CO. The purpose of the Bench-scale Steam Reformer (BSR) testing was to demonstrate that the same reactions occur and the same product is formed when steam reforming actual radioactive Tank $48 \mathrm{H}$ waste.

The approach used in the current study was to test the BSR with the same Tank 48H simulant and same Erwin coal as was used at the ESTD FBSR under the same operating conditions. This comparison would allow verification that the same chemical reactions occur in both the BSR and ESTD FBSR. Then, actual radioactive Tank $48 \mathrm{H}$ material would be steam reformed in the BSR to verify that the actual tank $48 \mathrm{H}$ sample reacts the same way chemically as the simulant Tank $48 \mathrm{H}$ material.

The conclusions from the BSR study and comparison to the ESTD FBSR are the following:

A Bench-scale Steam Reforming (BSR) unit was successfully designed and built that:

- Emulated the chemistry of the ESTD FBSR Denitration Mineralization Reformer (DMR) and Carbon Reduction Reformer (CRR) known collectively as the dual reformer flowsheet.

- Measured and controlled the off-gas stream.

- Processed real (radioactive) Tank $48 \mathrm{H}$ waste.

- Met the standards and specifications for radiological testing in the Savannah River National Laboratory (SRNL) Shielded Cells Facility (SCF).

Three runs with radioactive Tank $48 \mathrm{H}$ material were performed.

The Tetraphenylborate (TPB) was destroyed to $>99 \%$ for all radioactive Bench-scale tests.

- The feed nitrate/nitrite was destroyed to $>99 \%$ for all radioactive BSR tests the same as the ESTD FBSR.

- The radioactive Tank $48 \mathrm{H}$ DMR product was primarily made up of soluble carbonates. The three most abundant species were thermonatrite, $\left[\mathrm{Na}_{2} \mathrm{CO}_{3} \cdot \mathrm{H}_{2} \mathrm{O}\right.$ ], sodium carbonate, [ $\left.\mathrm{Na}_{2} \mathrm{CO}_{3}\right]$, and trona, $\left[\mathrm{Na}_{3} \mathrm{H}\left(\mathrm{CO}_{3}\right)_{2} \cdot 2 \mathrm{H}_{2} \mathrm{O}\right]$ the same as the ESTD FBSR.

Insoluble solids analyzed by X-Ray Diffraction (XRD) did not detect insoluble carbonate species. However, they still may be present at levels below $2 \mathrm{wt} \%$, the sensitivity of the XRD methodology. Insoluble solids XRD characterization indicated that various $\mathrm{Fe} / \mathrm{Ni} / \mathrm{Cr} / \mathrm{Mn}$ phases are present. These crystalline phases are associated with the insoluble sludge components of Tank $48 \mathrm{H}$ slurry and impurities in the Erwin coal ash. The percent insoluble 
solids, which mainly consist of un-burnt coal and coal ash, in the products were 4 to $11 \mathrm{wt} \%$ for the radioactive runs.

- The $\mathrm{Fe}^{+2} / \mathrm{Fe}_{\text {total }}$ REDOX measurements ranged from 0.58 to 1 for the three radioactive Benchscale tests. REDOX measurements $>0.5$ showed a reducing atmosphere was maintained in the DMR indicating that pyrolysis was occurring.

Greater than $90 \%$ of the radioactivity was captured in the product for all three runs.

- The collective results from the FBSR simulant tests and the BSR simulant tests indicate that the same chemistry occurs in the two reactors.

- The collective results from the BSR simulant runs and the BSR radioactive waste runs indicates that the same chemistry occurs in the simulant as in the real waste.

The FBSR technology has been proven to destroy the organics and nitrates in the Tank $48 \mathrm{H}$ waste and form the anticipated solid carbonate phases as expected. 


\section{TABLE OF CONTENTS}

EXECUTIVE SUMMARY V

LIST OF FIGURES ....................................................................................................... VIII

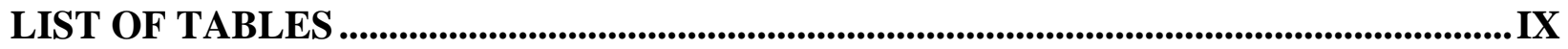

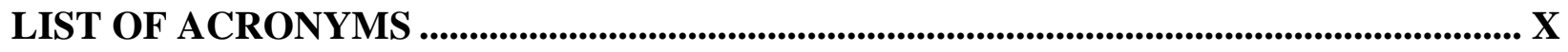

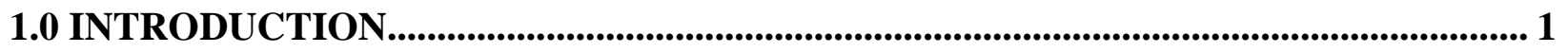

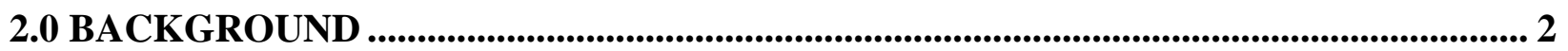

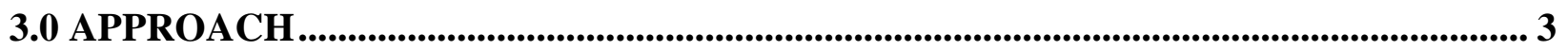

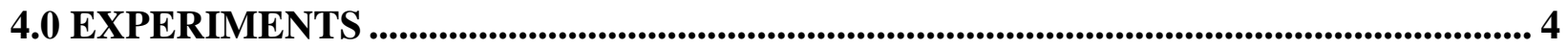

4.1 BENCH-SCALE STEAM REFORMER DESCRIPTION .............................................. 4

4.2 BSR OPERATING CONDITIONS FOR ACTUAL TANK 48H WASTE...................... 15

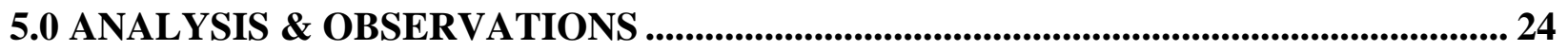

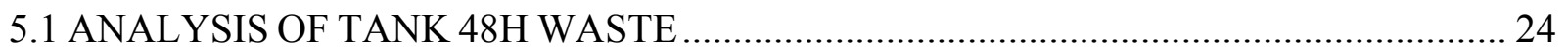

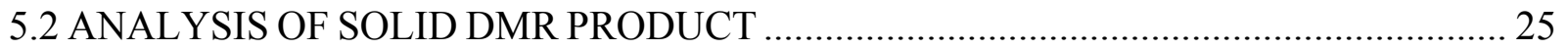

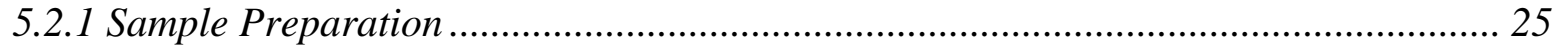

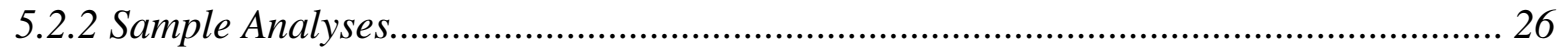

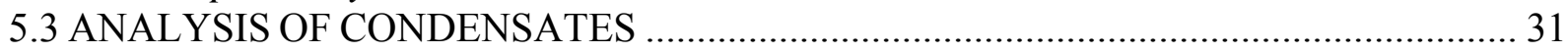

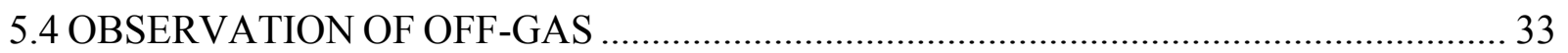

5.5 COMPARISON OF SIMULANT WASTE WITH ACTUAL WASTE............................ 34

5.6 COMPARISON OF DMR PRODUCTS AND KEY PROCESS CONDITIONS .............. 36

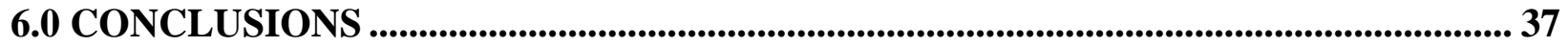

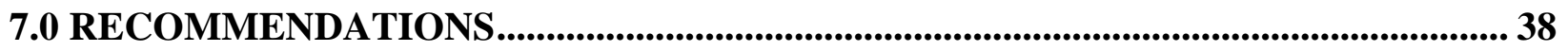

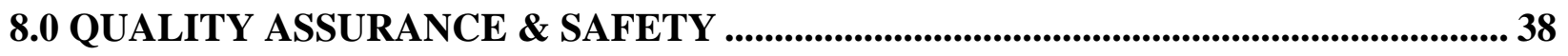

APPENDIX 1. XRD GRAPHS OF DMR PRODUCTS ............................................... 39

APPENDIX 2. CALCULATION OF RADIOACTIVE DISTRIBUTION .......................... 43

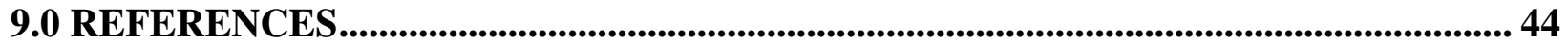




\section{LIST OF FIGURES}

Figure 1. Schematic of the Bench-Scale Steam Reformer...................................................... 4

Figure 2. The Denitration Mineralization Reformer ......................................................... 5

Figure 3. DMR Temperature Gradient Around Control Thermocouple ................................... 6

Figure 4. The Condenser / Bubbler / Dry Ice Condenser ............................................ 7

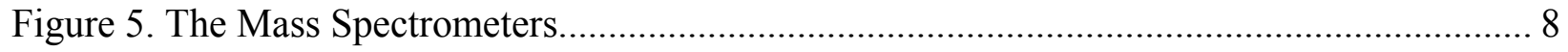

Figure 6. The Carbon Reduction Reformer ...................................................................... 9

Figure 7. BSR Pan Layout for Cell (Simplified) ................................................................. 10

Figure 8. BSR Process Control Diagram ........................................................................ 11

Figure 9. Total System Layout at Cell 4 (Simplified) ........................................................ 14

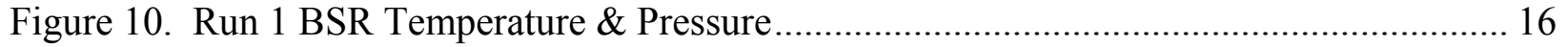

Figure 11. Run 2 BSR Temperature \& Pressure................................................................ 16

Figure 12. Run 3 BSR Temperature \& Pressure.................................................................. 17

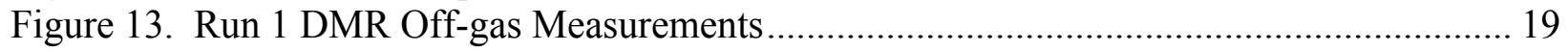

Figure 14. Run 1 DMR Off-gas $\mathrm{H}_{2}$ \& Air Flow .................................................................. 19

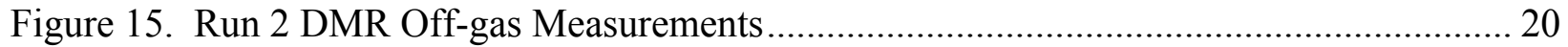

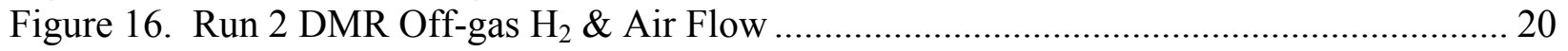

Figure 17. Run 3 DMR Off-gas Measurements ........................................................... 21

Figure 18. Run 3 DMR Off-gas $\mathrm{H}_{2}$ \& Air Flow.............................................................. 21

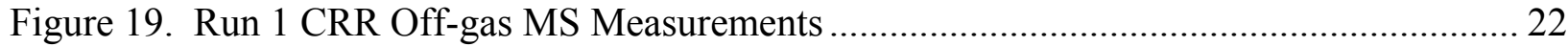

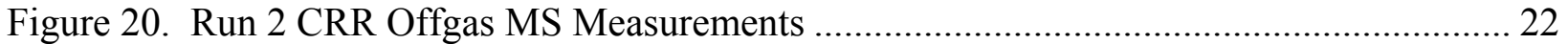

Figure 21. Run 3 CRR Offgas MS Measurements ............................................................. 23

Figure A-1. Run 1 Bottom Product XRD ....................................................................... 40

Figure A-2. Run 1 Bottom Insoluble Solids XRD ................................................................ 40

Figure A-3. Run 2 Bottom Product XRD ...................................................................... 41

Figure A-4. Run 2 Bottom Insoluble Solids XRD ............................................................. 41

Figure A-5. Run 3 Bottom Product XRD ............................................................................. 42

Figure A-6. Run 3 Bottom Insoluble Solids XRD ............................................................. 42 


\section{LIST OF TABLES}

Table 1. M\&TE Associated Equipment 12

Table 2. Mass Spectrometer Calibration Checks...... 13

Table 3. BSR Process Operation Conditions compared to Pilot-Scale FBSR Conditions for Prod$4^{1}$ 15

Table 4. DMR Mass Spectrometer Off-gas Measurement Summary Data (vol\%) ................... 18

Table 5. CRR Mass Spectrometer Off-gas Measurement Summary Data (vol\%) .................... 18

Table 6. Radioactive Tank 48H Data of HTF-E-05-021 Slurry Sample ${ }^{6}$................................. 24

Table 7. The High Pressure Liquid Chromotography (HPLC) results of HTF-E-05-021 T48

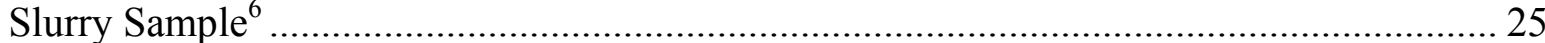

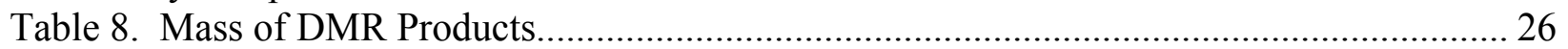

Table 9. DMR Product HPLC Analyses for Organics ......................................................... 26

Table 10. DMR and Insoluble Phase Analysis by X-Ray Diffraction (XRD) .......................... 27

Table 11. DMR REDuction/OXidation (REDOX) of Product ............................................. 27

Table 12. DMR Anions in mg/L of Dissolved Product ...................................................... 28

Table 13. Soluble Cations from DMR Product vs Feed .......................................................... 29

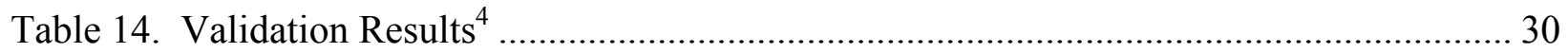

Table 15. Organic Analyses of Condensates ...................................................................... 32

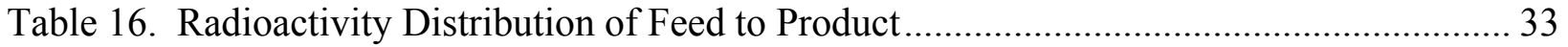

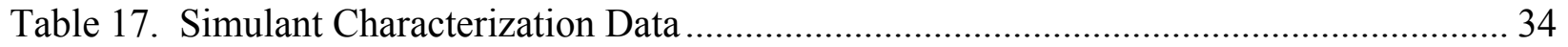

Table 18. Tank 48H Simulant vs Actual Tank 48H Waste Comparison .................................. 35

Table 19. FBSR Simulant vs BSR Simulant vs BSR Tk48H Waste Comparison...................... 36 


\section{LIST OF ACRONYMS}

\begin{tabular}{|c|c|}
\hline ADD & Analytic Development Directorate \\
\hline BSR & Bench-scale Steam Reformer \\
\hline CHAP & Consolidated Hazard Analysis Package \\
\hline CRR & Carbon Reduction Reformer \\
\hline Cs-TPB & Cesium Tetraphenylborate \\
\hline $\mathrm{d} / \mathrm{m} / \mathrm{ml}$ & disintegrations/minute/milliliter \\
\hline DMR & Denitration Mineralization Reformer \\
\hline DOE & Department of Energy \\
\hline DSA & Design Safety Analysis \\
\hline DWPF & Defense Waste Processing Facility \\
\hline ESTD FBSR & Engineering Scale Test Demonstration Fluidized Bed Steam Reforming \\
\hline FBSR & Fluidized Bed Steam Reformer or Reforming \\
\hline GC & Gas Chromatograph \\
\hline HAP & Hazards Analysis Package \\
\hline HLW & High Level Waste \\
\hline HPLC & High Pressure Liquid Chromotography \\
\hline HRI & Hazen Research Inc. \\
\hline $\mathrm{IC}$ & Ion Chromotography \\
\hline ICP-ES & Inductively Coupled Plasma Emission Spectroscopy \\
\hline inwc & INches Water Column \\
\hline ITP & In-Tank Precipitation \\
\hline KAPL & Knolles Atomic Power Laboratory \\
\hline LFL & Lower Flammability Limit \\
\hline LWO & Liquid Waste Operations \\
\hline MS & Mass Spectrometer \\
\hline $\mathrm{Na}-\mathrm{TPB}$ & Sodium Tetraphenylborate \\
\hline $\mathrm{PC}$ & Personal Computer \\
\hline REDOX & REDuction/OXidation \\
\hline $\mathrm{sccm}$ & standard cubic centimeters per minute \\
\hline $\mathrm{SCF}$ & Shielded Cells Facility \\
\hline SLM & Standard Liters per Minute \\
\hline SRNL & Savannah River National Laboratory \\
\hline SRS & Savannah River Site \\
\hline SVOA & Semi-Volatile Organic Analyses \\
\hline THOR $^{(B)}$ & THermal Organic Reduction \\
\hline ТРB & TetraPhenylBorates \\
\hline TTR & Task Technical Request \\
\hline TTT & THOR ${ }^{\circledR}$ Treatment Technologies \\
\hline TT\&QAP & Task Technical and Quality Assurance Plan \\
\hline VOA & Volatile Organic Analyses \\
\hline XRD & X-Ray Diffraction \\
\hline
\end{tabular}




\subsection{INTRODUCTION}

Fluidized Bed Steam Reforming (FBSR) is being considered as a potential technology for the removal of Tetraphenylborate, (TPB) and other organics due to the breakdown of TPB from the Tank $48 \mathrm{H}$ waste. The desired plan was to develop a laboratory scale system that provides the same gas reactions and atmosphere and solid phase chemistry as in the Engineering Scale Test Demonstration Fluidized Bed Steam Reforming (ESTD FBSR) test ${ }^{1}$ performed in 2006 . The laboratory scale system would then be operated with the same simulant as was used in the ESTD FBSR, and then repeat the operation using the actual radioactive Tank $48 \mathrm{H}$ waste. In this way, the simulant run data between the ESTD FBSR and the laboratory scale system could be compared to determine if both reactors provide the same chemistry, then the actual waste run data and the simulant run data from the laboratory scale system could be compared to determine if the actual waste behaves the same as the simulant.

The actual Tank $48 \mathrm{H}$ waste demonstration had to be performed in the SRNL Shielded Cells Facility (SCF) due to its radioactivity, mostly Cs-137. There was no known FBSR system that was small enough to fit inside the shielded cells or that could be operated remotely using cell manipulators. Thus the Savannah River National Laboratory (SRNL) developed the Bench-scale Steam Reformer (BSR) to fulfill this need.

Liquid Waste Operations (LWO) personnel at the Savannah River Site (SRS) issued a Task Technical Request (TTR) for the bench-scale steam reforming of radioactive Tank 48H samples related to FBSR technology using the carbonate flowsheet. ${ }^{2}$

Engineering Process Development personnel at the SRNL issued a Task Technical and Quality Assurance Plan (TT\&QAP) ${ }^{3}$ and a validation plan ${ }^{4}$ to address the testing criteria and objectives for the radioactive bench-scale steam reforming work. The purposes of the study were to demonstrate the following objectives with actual radioactive Tank $48 \mathrm{H}$ material:

- Design and fabricate a Bench scale Steam Reforming (BSR) unit that:

- Emulates the chemistry of the ESTD FBSR Denitration Mineralization Reformer (DMR) and Carbon Reduction Reformer (CRR) known collectively as the dual reformer flowsheet.

- Characterizes the Off-Gas product stream.

- Can process real (radioactive) Tank 48H waste.

- Meets standards and specifications for radiological testing.

- Perform three runs with radioactive Tank $48 \mathrm{H}$ material.

- Characterize product chemistries to show 1) $>99 \%$ destruction of feed TPB, 2) $>99 \%$ destruction of feed nitrates and nitrites, 3 ) the majority of solid product is in the carbonate form, and 4) the chemistry in the DMR was reducing.

- Measure and control BSR off-gas on a real time basis. 


\subsection{BACKGROUND}

Tank $48 \mathrm{H}$ currently holds approximately 240,000 gallons of legacy waste from the In-Tank Precipitation (ITP) project, containing organic tetraphenylborate (TPB) solids, and is incompatible with other waste treatment processes at Savannah River Site (SRS). Consequently, Tank $48 \mathrm{H}$ remains isolated from Tank Farm operations. Returning Tank $48 \mathrm{H}$ to service on a schedule is critical to meet the Tank Farm mission and the tank space management program.

After several well-documented evaluations, the Fluidized Bed Steam Reforming (FBSR) technology was selected as the primary technology capable of safely and cost-effectively dispositioning the Tank 48 waste in a manner compatible with current tank farm operations.

Steam reforming destroys organics by the water gas shift reactions at temperatures above $600^{\circ} \mathrm{C}$. Any carbon bearing species is converted to $\mathrm{CO}$ and $\mathrm{CO}_{2}$ as $\mathrm{H}_{2} \mathrm{O}$ becomes $\mathrm{H}_{2}$.

$\mathrm{C}(\mathrm{s})+\mathrm{H}_{2} \mathrm{O}(\mathrm{g}) \rightarrow \mathrm{CO}(\mathrm{g})+\mathrm{H}_{2}(\mathrm{~g})$

$\mathrm{H}_{2} \mathrm{O}(\mathrm{g})+\mathrm{CO}(\mathrm{g}) \rightarrow \mathrm{H}_{2}(\mathrm{~g})+\mathrm{CO}_{2}(\mathrm{~g})$

In addition to destroying the organics, the $\mathrm{CO}$ and $\mathrm{H}_{2}$ rich atmosphere then promote the denitration of the salt solution.

$\mathrm{CO}(\mathrm{g})+\mathrm{NO}_{2}(\mathrm{~g}) \rightarrow \mathrm{CO}_{2}(\mathrm{~g})+\mathrm{NO}(\mathrm{g})$

$2 \mathrm{CO}(\mathrm{g})+2 \mathrm{NO}(\mathrm{g}) \rightarrow 2 \mathrm{CO}_{2}(\mathrm{~g})+\mathrm{N}_{2}(\mathrm{~g})$

$\mathrm{H}_{2}(\mathrm{~g})+\mathrm{NO}_{2}(\mathrm{~g}) \rightarrow \mathrm{H}_{2} \mathrm{O}(\mathrm{g})+\mathrm{NO}(\mathrm{g})$

$2 \mathrm{H}_{2}(\mathrm{~g})+2 \mathrm{NO}(\mathrm{g}) \rightarrow 2 \mathrm{H}_{2} \mathrm{O}(\mathrm{g})+\mathrm{N}_{2}(\mathrm{~g})$

Typically, the $\mathrm{H}_{2}$ concentration was controlled to about $2 \%$ on a dry basis in order to completely reduce the $\mathrm{NO}_{\mathrm{x}}$ gases to steam and $\mathrm{N}_{2}$. It was controlled by adding air to create more steam and heat.

$2 \mathrm{H}_{2}(\mathrm{~g})+\mathrm{O}_{2}(\mathrm{~g}) \rightarrow 2 \mathrm{H}_{2} \mathrm{O}(\mathrm{g})+$ heat

Off-gases from the steam reformer still included some organics so a second reformer operated at $925^{\circ} \mathrm{C}$ with excess air to oxidize the remaining organics fully to $\mathrm{CO}_{2}$ and to convert the remaining $\mathrm{H}_{2}$ to steam $\left(\mathrm{H}_{2} \mathrm{O}\right.$ gas $)$.

The steam reformer creates a solid carbonate product which is readily soluble in water for further processing.

$5 \mathrm{C}(\mathrm{s})+4 \mathrm{NaNO}_{3} \rightarrow 3 \mathrm{CO}_{2}(\mathrm{~g})+2 \mathrm{Na}_{2} \mathrm{CO}_{3}(\mathrm{~s})+2 \mathrm{~N}_{2}(\mathrm{~g})$

Thermonatrite, $\left[\mathrm{Na}_{2} \mathrm{CO}_{3} \cdot \mathrm{H}_{2} \mathrm{O}\right.$ ], Sodium Carbonate, $\left[\mathrm{Na}_{2} \mathrm{CO}_{3}\right.$ ], and Trona, $\left[\mathrm{Na}_{3} \mathrm{H}\left(\mathrm{CO}_{3}\right)_{2} \cdot 2 \mathrm{H}_{2} \mathrm{O}\right.$ ] are the major carbonate products formed from an alkali rich waste and the $\mathrm{CO}-\mathrm{CO}_{2}$ reactions in the FBSR.

Note that these reactions represent the overall chemistry, but are not all inclusive. 
An FBSR can be electrically heated externally if the diameter of the reaction chamber is small enough. For larger diameter FBSR units, heat must be generated in an auto-thermal mode. For auto-thermal operation the energy needs are supplied by the incoming superheated steam and by the oxidation of organics from the waste and carbon reductants. In the ESTD FBSR, Erwin coal was added to the DMR as fuel to provide the necessary auto-thermal heat. The BSR did not require the coal for heat since it was small; however excess coal was added to the BSR to provide some of the heat to closer mimic the FBSR.

The Erwin coal also reacted with the nitrate salts in the feed to form a carbonate product and $\mathrm{NO}_{\mathrm{x}}$ gases. Finally, the coal reacted with the superheated steam to produce the water gas shift reactions which produced $\mathrm{H}_{2}, \mathrm{CO}$, and $\mathrm{CO}_{2}$. The $\mathrm{H}_{2}$ and $\mathrm{CO}$ reacted with the $\mathrm{NO}_{\mathrm{x}}$ gases to form $\mathrm{H}_{2} \mathrm{O}, \mathrm{CO}_{2}$, and $\mathrm{N}_{2}$. Oxygen was added to the DMR to control the hydrogen concentration in the DMR process outlet gas to between $2 \%$ to $3 \%$ on a dry basis which was an adequate concentration to ensure that all the $\mathrm{NO}_{\mathrm{x}}$ gases were consumed ${ }^{1}$.

Erwin coal was chosen by THOR ${ }^{\circledR}$ Treatment Technologies (TTT) because it is very reactive at low temperatures. Also, the Erwin coal was calcined to remove volatiles, sulfur, and nitrogen so that it burned cleaner in the FBSR.

\subsection{APPROACH}

Initially, the SRS LWO customer requested TTT to perform pilot scale tests on Tank 48H simulant at the Hazen Research Institute (HRI) in Golden, Colorado. These tests were performed during October 2006. The conditions for the PROD-4 run ${ }^{1}$ were chosen for the BSR tests because these conditions were the most reactive at $670^{\circ} \mathrm{C}$, produced the least amount of residual coal, and did not degrade the carbonate product.

Thus the first runs performed with the BSR were with the same process conditions, the same Tank $48 \mathrm{H}$ simulant, and the same Erwin coal as was used during the PROD-4 runs at HRI. Once two successful runs were completed using the simulant, three runs were performed in the radioactive $\mathrm{BSR}$ using actual Tank $48 \mathrm{H}$ waste. In the radioactive runs, the same process conditions and the same Erwin coal were used as was used during the BSR simulant runs. 


\subsection{EXPERIMENTS}

\subsection{BENCH-SCALE STEAM REFORMER DESCRIPTION}

The BSR designed at SRNL is a two-stage unit used to produce the same mineralized products and gases as the ESTD FBSR. A schematic of the unit designed is shown in Figure 1.

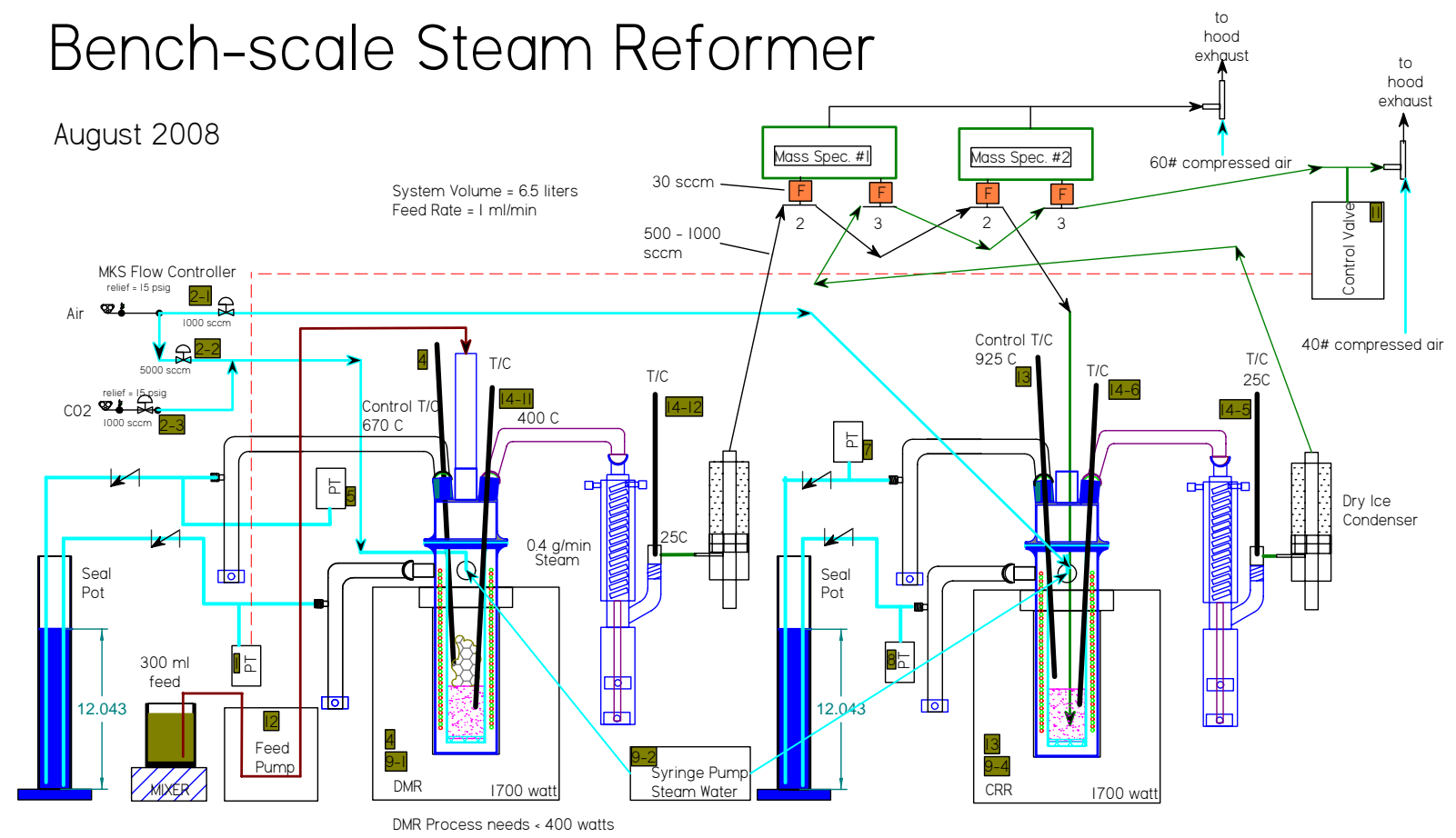

Figure 1. Schematic of the Bench-Scale Steam Reformer

The nomenclature for the two reformers came directly from the ESTD FBSR unit. Approximately $300 \mathrm{ml}$ of feed slurry was kept agitated with a stir bar mixer while a peristaltic pump fed the slurry through the center feed port in the lid of the Denitration Mineralization Reformer (DMR) at about $1 \mathrm{ml} / \mathrm{min}$. A solid carbonate product formed in the DMR in the presence of superheated steam and carbon and the off-gases flowed toward the DMR condenser. The condenser cooled the off-gas stream down to about $25^{\circ} \mathrm{C}$ and removed the steam. A bubbler in the trap section of the condenser removed particulate carry-over which mainly consisted of the fine coal additive. The off-gas was further cooled by a dry ice condenser prior to being measured by a Mass Spectrometer (MS) for $\mathrm{H}_{2}, \mathrm{O}_{2}, \mathrm{CO}_{2}, \mathrm{~N}_{2}, \mathrm{C}_{6} \mathrm{H}_{6}$, and argon. The off-gas then flowed into the Carbon Reduction Reformer (CRR) where any $\mathrm{CO}, \mathrm{H}_{2}, \mathrm{C}_{6} \mathrm{H}_{6}$, or other oxidizable species would be converted to $\mathrm{H}_{2} \mathrm{O}$ and $\mathrm{CO}_{2}$. The off-gas leaving the CRR received the same treatment as the off-gas leaving the DMR before being measured by a MS for the same gases. An eductor drew the gases through the system and expelled them into the cell along with the motive air used to operate it. A control valve bled air into the suction side of the eductor to control the pressure of the DMR outer chamber to -2 inches of water column (inwc). 


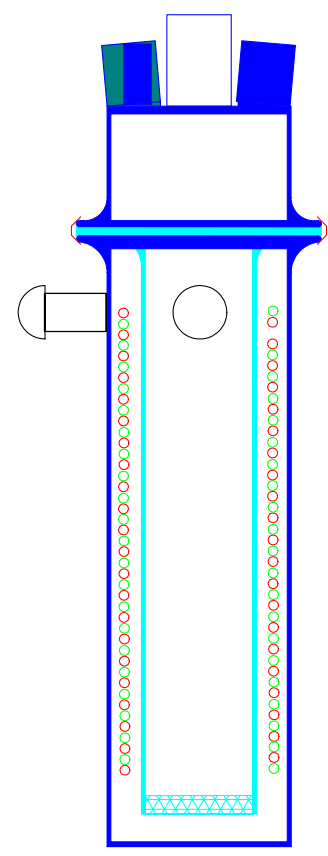

Figure 2. The Denitration Mineralization Reformer

The Denitration Mineralization Reformer (DMR) received the Tank 48H waste stream (or simulant) as feed and converted it to a solid carbonate product in the presence of superheated steam and carbon. The DMR inner reaction chamber was $70 \mathrm{~mm}$ ID $\times 385 \mathrm{~mm}$ tall with a porous bottom. The bottom $75 \mathrm{~mm}$ was filled with zirconia beads (not shown). The zirconia beads were heavy enough not to be suspended by the gases and steam flowing up past them, acted as a base for the product to form on, allowed easy removal of the product from the reaction chamber, allowed easy separation of the product from the beads for analytic purposes, and provided a heat transfer medium for the gases that flowed up through them. Zirconia beads are inert at the temperatures and oxygen fugacity at which the DMR operated and did not affect the steam reforming chemistry.

The DMR outer chamber was $120 \mathrm{~mm}$ ID x 400mm and provided connections for the outer chamber pressure relief and measurement line, and each of the two 20 foot coils which were housed between the DMR inner reaction chamber and the outer chamber. The outer chamber was sealed by the top flange of the inner chamber and thus had a pressure relief line going to a seal pot which relieved at about 15 inwc. Water, $\mathrm{CO}_{2}$, and air entered the DMR via the coils which were between the inner and outer walls of the DMR and were converted to superheated steam and hot gases with heat provided by the furnace that the DMR sat in. The steam and gases left the coils and flowed through the bottom of the DMR inner reaction chamber, the zirconia beads, the product, and out through the top of the DMR to the DMR condenser. The $\mathrm{CO}_{2}$ flow rate was a constant based on the HRI PROD- $4^{1}$ conditions. The air flow rate was varied in order to control the $\mathrm{H}_{2}$ concentration leaving the reactor from $1.5 \%$ to $4 \%$ on a dry basis which was close to the Hazen PROD- 4 run condition of $2 \%-3 \%$. The DMR inner reaction chamber could 
hold about 70 grams of product which was converted from about $300 \mathrm{ml}$ of Tank $48 \mathrm{H}$ waste with 60 grams of Erwin coal added.

The maximum height requirement in the shielded cells prevented having a fluidized bed steam reformer. There was not enough height to allow for proper disengagement of the product from the off-gas stream. Therefore the BSR was not fluidized, so the product formed a porous stalagmite on the top of the zirconia beads at the bottom of the DMR reaction chamber as the feed was dripped onto them from the top, center of the reactor.

The same Erwin coal was added as was used by the ESTD FBSR as a reducing agent. However, for the BSR, the coal was ground, then sifted through an 80 mesh sieve (177 microns) and mixed with the feed slurry prior to being pumped into the DMR versus the ESTD coal which was much larger and was added as a separate stream in the FBSR. In addition, a 1.3 gram amount of $\mathrm{Fe}\left(\mathrm{NO}_{3}\right)_{3} \bullet 9 \mathrm{H}_{2} \mathrm{O}$ was added to the BSR runs to act as an analytical indicator for the REDuction/OXidation (REDOX) potential in the product. The REDOX measurement was used to determine the oxygen fugacity inside the DMR and ensure that pyrolysis was occurring under highly deoxygenated conditions, e.g. $-\log \mathrm{fO}_{2} \sim-20$.

The DMR lid was $120 \mathrm{~mm}$ ID $\times 80 \mathrm{~mm}$ and was sealed to the top of the inner chamber. The lid held two type $\mathrm{K}$ thermocouples, the centered feed line that was cooled with standing water, the inner chamber pressure relief and measurement line, and the off-gas line going to the DMR condenser. In the event that the off-gas line plugged, the inner chamber and lid had a pressure relief line going to a seal pot which relieved at about 15 inwc. One thermocouple was positioned at 1.5 inches into the zirconia bead bed and the control thermocouple was positioned 2 inches above the surface of the bead bed. The control temperature was $670^{\circ} \mathrm{C}$ in the DMR. Figure 3 shows that the first four inches of the stalagmite are formed in a region where the temperature is between $676^{\circ} \mathrm{C}$ and $645^{\circ} \mathrm{C}$ which is within the temperature range for making good product. Samples were taken from this region and analyzed separately from the upper samples.

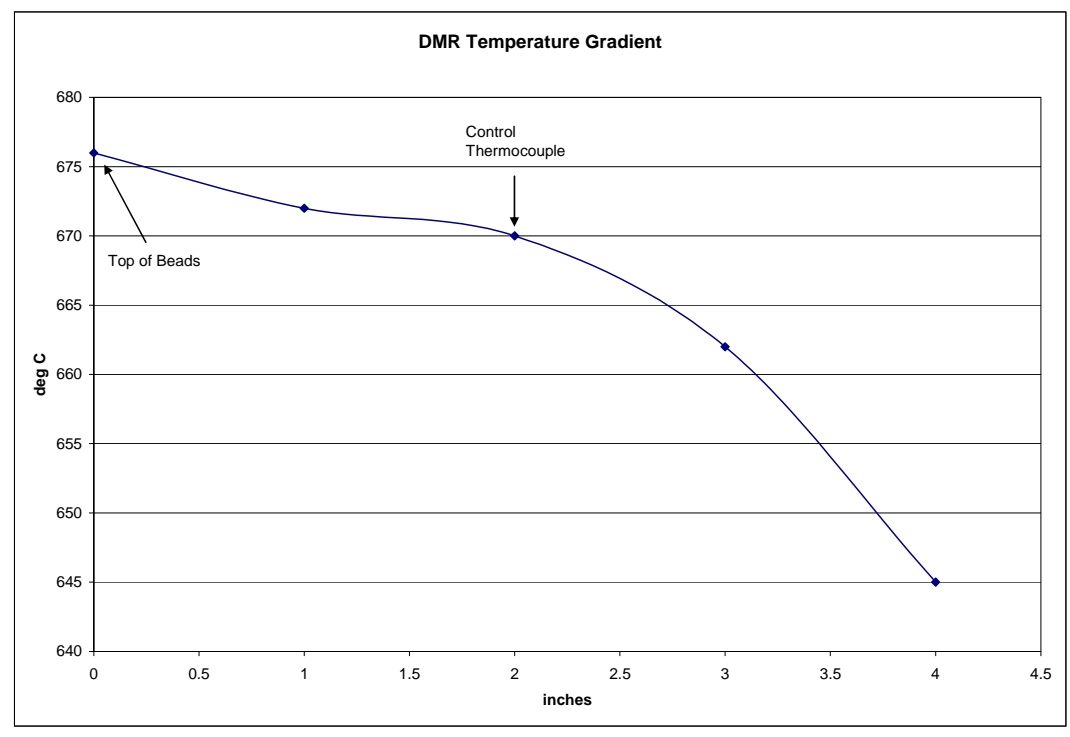

Figure 3. DMR Temperature Gradient Around Control Thermocouple 
SRNS-STI-2008-00105

Revision 0, 9/25/08

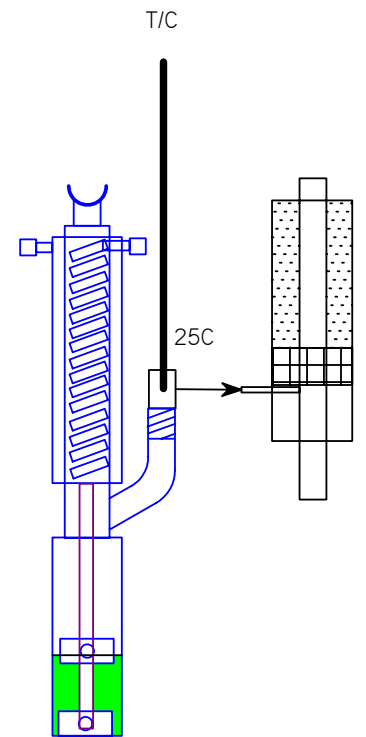

Figure 4. The Condenser / Bubbler / Dry Ice Condenser

The condenser/bubbler/dry ice condenser units were necessary for pretreatment of the off-gas to prevent filter pluggage or damage to the mass spectrometers.

The condenser was cooled by a chiller bath flowing approximately $1 \mathrm{gpm}$ of $5^{\circ} \mathrm{C}$ water through its inner coils and outer jacket. The off-gases and steam entered at the top of the condenser and flowed and condensed down through the center tube which ended at the bottom of a $75 \mathrm{~mm}$ deep water reservoir filled with zirconia beads. The water would overflow into a sealed reservoir (not shown), the particulate would accumulate in the water and on the walls, and the gases would bubble up through the water and exit past the thermocouple and into the dry ice condenser. The dry ice condenser was a 3 inch ID x 9 inch tall pipe with a 1 inch ID tube for off-gas flow inside. Dry ice was added in the annular space between the 1" tube and the 3" pipe. The dry ice condenser typically froze about $7 \mathrm{ml}$ of liquid per run which was drained out of the bottom after each run. If not sized correctly or if a large leak occurred in the system prior to the dry ice condenser, a plug could form. 


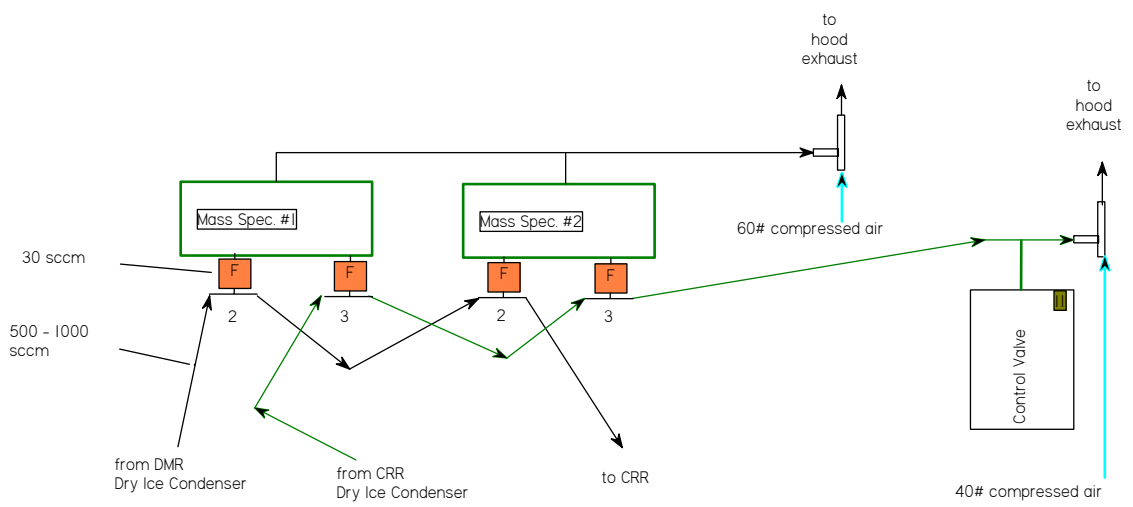

Figure 5. The Mass Spectrometers

The BSR used dual Monitor Instruments LAB 3000 Cycloidal mass spectrometers (MSs) for the dual reformers. Both spectrometers were set up identically to measure $\mathrm{H}_{2}, \mathrm{O}_{2}, \mathrm{~N}_{2}, \mathrm{CO}_{2}$, benzene, and argon. One MS would measure the DMR off-gas on channel 2 while the other MS measured CRR off-gas on channel 3. Channel 1 was used for the calibration gas for both MSs. Both channels 2 and 3 had 7 micron sintered metal filters in the $1 / 8$ " lines going to the instruments to prevent plugging the lines inside the MSs.

Since the line pressure near the MSs would be down to -25 inwc, it was necessary to run a second eductor and vacuum regulator to draw the sample gases through the MSs. The vacuum was controlled to -30 inwc while the flow rate of gases pulled by an MS sample line was kept at $30 \mathrm{sccm}$. The flow rate of the gases coming from the DMR dry ice condenser varied between 500 to $1000 \mathrm{sccm}$ while the flow rate of the gases coming from the CRR dry ice condenser were $400 \mathrm{sccm}$ greater because of the oxidizing air added to the CRR.

Both MSs were controlled by a single Personal Computer (PC) with Monitor Instruments proprietary software loaded. Data from the MS computer was transferred to the control computer in real time via serial connections. The $\mathrm{DMR}_{2}$ values were continuously trended on the control computer and operating personnel would manually vary the air flow into the DMR to control the DMR $\mathrm{H}_{2}$ value between $1.5 \%$ and $4 \%$. As an operator aid, the computer would automatically shut off the feed pump if the DMR $\mathrm{H}_{2}$ reached $12 \%$.

The MSs would determine and transmit the gas concentration data about once every 8 seconds. However, the lag time between the measurement and the conditions in the DMR ranged between 1 to 2 minutes depending on flow rates. The system was controlled within the limits about $80 \%$ of the time manually, but might have been improved with an automatic controller. 
SRNS-STI-2008-00105

Revision 0, 9/25/08

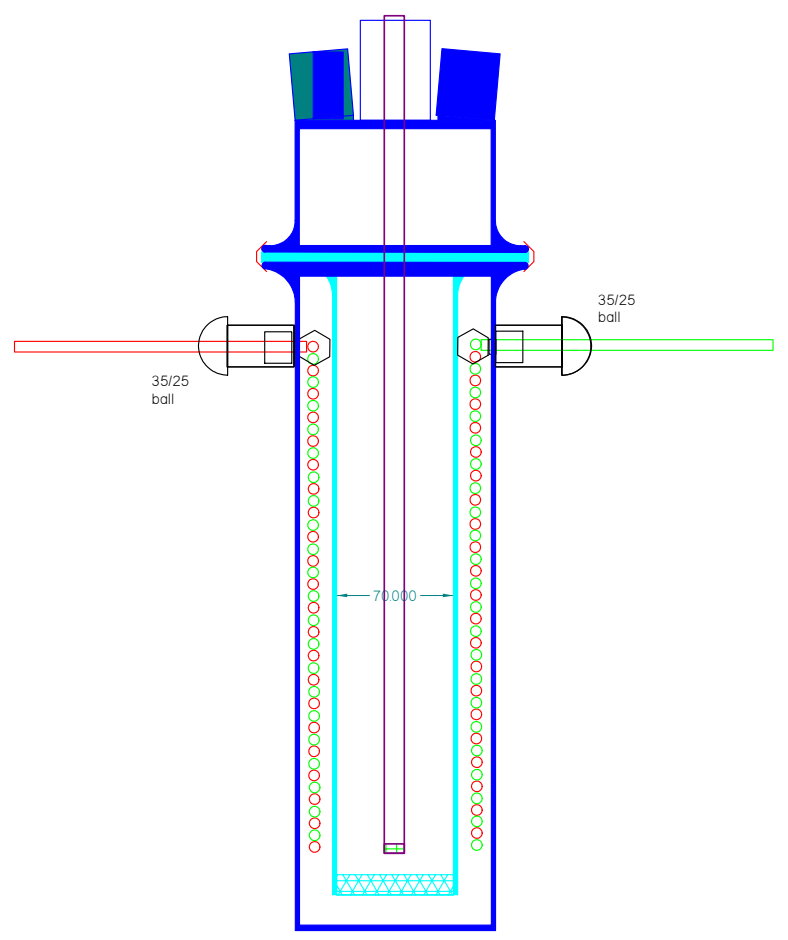

Figure 6. The Carbon Reduction Reformer

The CRR was essentially the same as the DMR except instead of having a feed line in the lid, it had a down-comer for the DMR off-gases to enter. The down-comer was a $13 \mathrm{~mm}$ diameter tube which ended $10 \mathrm{~mm}$ off the bottom of the inner basket. The inner basket was filled to $75 \mathrm{~mm}$ with zirconia beads (not shown) as in the DMR. Air and water flowed in through the two 20 foot heating coils to become hot air and superheated steam which flowed up through the inner basket and out through the lid to the CRR condenser.

The thermocouples had the same placement as the DMR and the control temperature was set to $925^{\circ} \mathrm{C}$. The sole purpose of this unit was to fully oxidize the gases which came from the DMR as done in the HRI/TTT dual reformer flowsheet. The steam does not enter into the reactions, but was added so that this unit mimicked the conditions in the ESTD FBSR CRR. 
SRNS-STI-2008-00105

Revision 0, 9/25/08

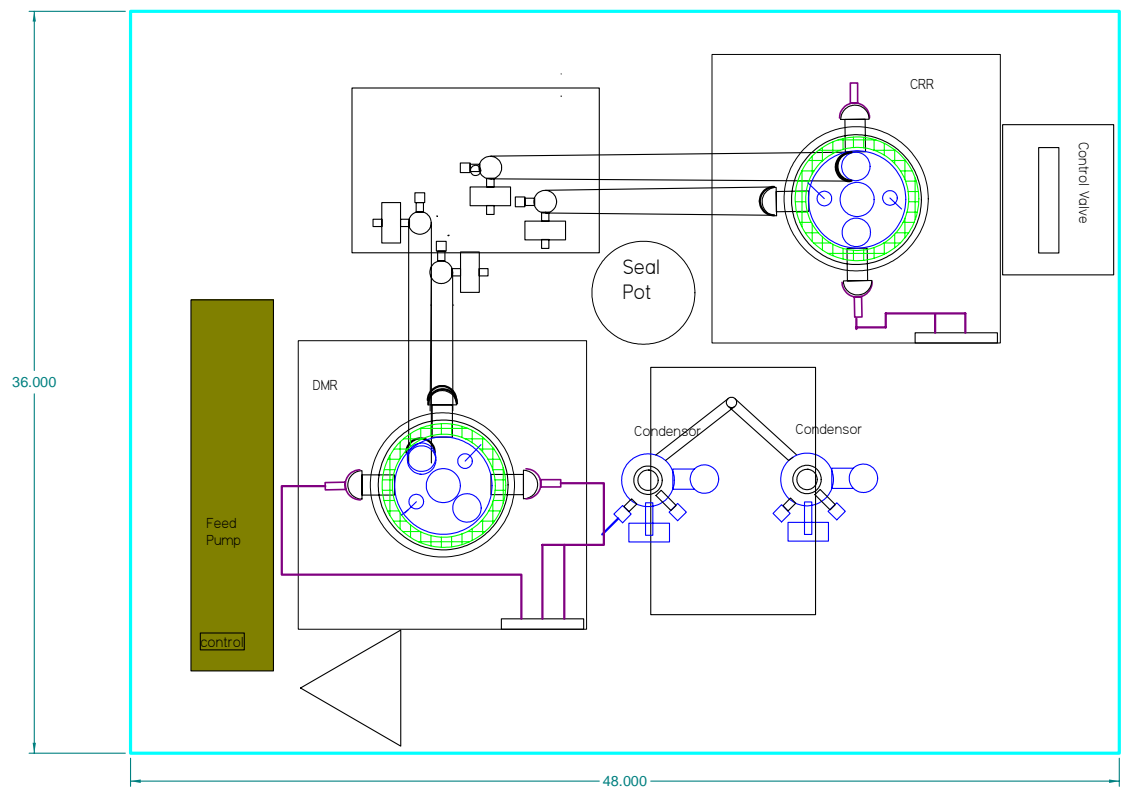

Figure 7. BSR Pan Layout for Cell (Simplified)

The BSR was assembled in the cells mockup shop on a 3' $x$ 4' stainless steel pan. Bolts were welded to the pan and the equipment was strapped to the pan using heavy duty wire ties. All the connections were made and the system was leak checked prior to placement into the cell. A special lifting yoke was fabricated and the BSR was lowered into the cell as a single unit using a crane. The estimated total weight of the BSR was 220 pounds and the weight distribution was fairly even as the pan canted less than $5^{\circ}$ to the CRR side. 
SRNS-STI-2008-00105

Revision 0, 9/25/08

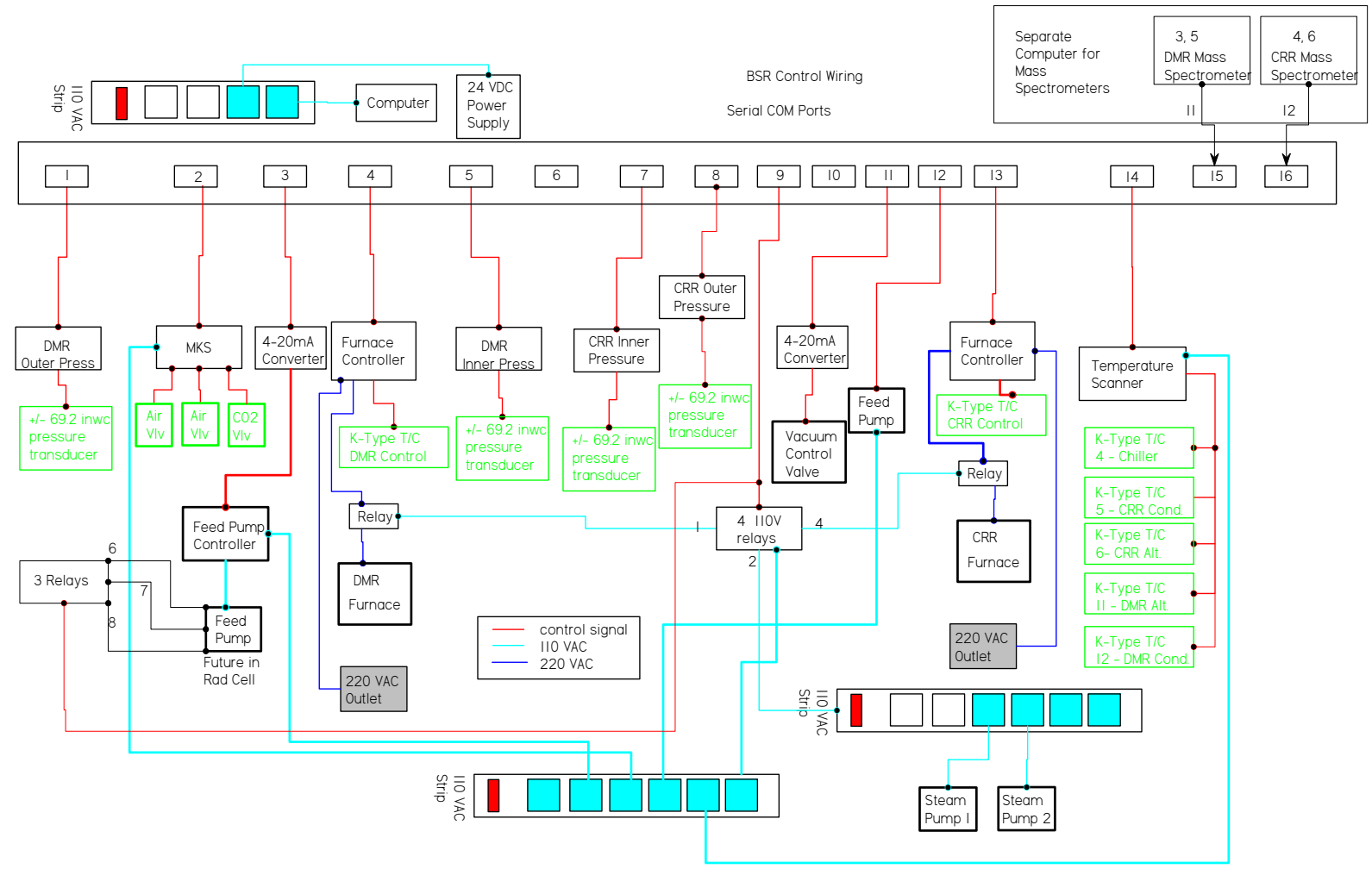

Figure 8. BSR Process Control Diagram

The BSR was controlled by a single PC running Windows XP with 16 serial port connections. Omniserver software was used as the server software to communicate through the serial ports. Intouch software was used as the client software and man machine interface. Data acquisition was continuous and trended in real time on screen as the process ran. Real time data was also saved to a file on a frequency of once per minute. Control logic was programmed into Intouch to provide operator aid (including a PID pressure controller). 
SRNS-STI-2008-00105

Revision 0, 9/25/08

Table 1. M\&TE Associated Equipment

\begin{tabular}{|l|c|c|c|c|c|}
\hline Name: & P1 & F2a & F2b & F2c & T4 \\
\hline Description: & $\begin{array}{c}\text { DMR } \\
\text { Outer } \\
\text { Pressure }\end{array}$ & CRR Air & DMR Air & DMR CO2 & DMR Ctrl Temp \\
\hline M\&TE \# & GT4-PB13 & FC1K-02 & FC5K-15 & FC1K-03 & GT4-PB20 \\
\hline Range & $+/-50$ inwc & $1000 \mathrm{sccm}$ & $5000 \mathrm{sccm}$ & $1000 \mathrm{sccm}$ & $0-1000 \mathrm{C}$ \\
\hline Error & $+0.1 /-0.4$ & $+6 /-5$ & $+0 /-39$ & $+0 /-8$ & $+0.6 /-3.0$ \\
\hline Name: & P5 & T14-11 & P7 & P8 & T13 \\
\hline Description: & $\begin{array}{c}\text { DMR Inner } \\
\text { Pressure }\end{array}$ & $\begin{array}{c}\text { DMR Alt. } \\
\text { Temp }\end{array}$ & $\begin{array}{c}\text { CRR Inner } \\
\text { Pressure }\end{array}$ & $\begin{array}{c}\text { CRR Outer } \\
\text { Pressure }\end{array}$ & CRR Ctrl Temp \\
\hline M\&TE \# & GT4-PB12 & GT4-PB24 & GT4-PB10 & GT4-PB11 & GT4-PB26 \\
\hline Range & $+/-50$ inwc & $0-1000 \mathrm{C}$ & $+/-50$ inwc & $+/-50$ inwc & $0-1000$ C \\
\hline Error & $+/-0.2$ & $+0.4 /-3.0$ & $+0.5 /-0.9$ & $+0.1 /-0.4$ & $+0 /-3.4$ \\
\hline & & & & & \\
\hline Name: & T14-12 & T14-6 & T14-5 & & \\
\hline Description: & $\begin{array}{c}\text { Condenser } \\
\text { Exit Temp }\end{array}$ & $\begin{array}{c}\text { CRR Alt. } \\
\text { Temp }\end{array}$ & $\begin{array}{c}\text { CRR Cond. } \\
\text { Exit Temp. }\end{array}$ & & \\
\hline M\&TE \# & GT4-PB22 & GT4-PB25 & GT4-PB33 & & \\
\hline Range & $0-200 \mathrm{C}$ & $0-1000 \mathrm{C}$ & $0-200 \mathrm{C}$ & & \\
\hline Error & $+0.6 /-1.6$ & $+0 /-3.6$ & $+0.2 /-1.7$ & & \\
\hline
\end{tabular}

Table 1 shows the measuring equipment that was calibrated at the Standards Laboratory for the BSR.

Process parameters measured were:

DMR outer pressure, DMR Inner Pressure, DMR Bed Temperature, DMR Control Temperature, DMR Condenser Temperature, DMR $\mathrm{H}_{2}, \mathrm{DMR} \mathrm{O}_{2}, \mathrm{DMR} \mathrm{N}_{2}, \mathrm{DMR} \mathrm{CO}_{2}$, DMR benzene, DMR argon, CRR outer pressure, CRR Inner Pressure, CRR Bed Temperature, CRR Control Temperature, CRR Condenser Temperature, CRR $\mathrm{H}_{2}, \mathrm{CRR} \mathrm{O}_{2}, \mathrm{CRR} \mathrm{N}_{2}, \mathrm{CRR} \mathrm{CO}_{2}, \mathrm{CRR}$ benzene, CRR argon, and chiller bath temperature.

Process parameters controlled were:

Slurry Feed Rate, DMR Control Temperature, DMR outer pressure, DMR $\mathrm{H}_{2}, \mathrm{DMR} \mathrm{CO}_{2}$ flowrate, DMR Air flow-rate, CRR Control Temperature, CRR Air flow-rate. 
SRNS-STI-2008-00105

Revision 0, 9/25/08

Each MS was calibrated before and after each run with the certified calibration gas standard.

The certification of analysis for the gases can be found on page 97 in the Laboratory Notebook ${ }^{5}$.

Table 2. Mass Spectrometer Calibration Checks

\begin{tabular}{|c|c|c|c|c|c|c|}
\hline Run & Standard & Pre -1 & Post-1 & Pre -2 & Post-2 & Post-3 \\
\hline Mass Spec \#1 & & & & & Pre-3 & \\
\hline Date & & $8 / 5 / 2008$ & $8 / 6 / 2008$ & $8 / 7 / 2008$ & $8 / 11 / 2008$ & $8 / 12 / 2008$ \\
\hline Hydrogen & 1.01 & 1.0178 & 0.998 & 1.0131 & 1.025 & 1.023 \\
\hline Oxygen & 4.12 & 4.2514 & 4.0931 & 4.1886 & 4.308 & 4.256 \\
\hline Nitrogen & 60.8644 & 61.8957 & 60.3563 & 61.4151 & 63.038 & 62.645 \\
\hline Carbon Dioxide & 29.94 & 30.052 & 29.3349 & 30.2803 & 30.561 & 30.694 \\
\hline Benzene & 0.0256 & 0.0251 & 0.0247 & 0.0252 & 0.0257 & 0.0262 \\
\hline Argon & 4.04 & 4.0833 & 3.9807 & 4.1003 & 4.186 & 4.169 \\
\hline \multicolumn{7}{|l|}{ Mass Spec \#2 } \\
\hline Hydrogen & 1.01 & 1.008 & 0.9635 & 0.9791 & 0.9875 & 0.9589 \\
\hline Oxygen & 4.12 & 4.119 & 3.9044 & 4.0293 & 4.183 & 4.004 \\
\hline Nitrogen & 60.8644 & 61.797 & 58.9369 & 60.6851 & 62.812 & 60.238 \\
\hline Carbon Dioxide & 29.94 & 30.16 & 28.6782 & 29.8116 & 30.81 & 29.659 \\
\hline Benzene & 0.0256 & 0.0277 & 0.0221 & 0.0224 & 0.0226 & 0.0224 \\
\hline Argon & 4.04 & 4.079 & 3.8639 & 4.0141 & 4.17 & 4 \\
\hline Mass Spec \#1 & & \%Error & \%Error & \%Error & \%Error & \%Error \\
\hline Hydrogen & & 0.77 & -1.19 & 0.31 & 1.49 & 1.29 \\
\hline Oxygen & & 3.19 & -0.65 & 1.67 & 4.56 & 3.30 \\
\hline \begin{tabular}{|l|} 
Nitrogen \\
\end{tabular} & & 1.69 & -0.83 & 0.90 & 3.57 & 2.93 \\
\hline Carbon Dioxide & & 0.37 & -2.02 & 1.14 & 2.07 & 2.52 \\
\hline Benzene & & -1.95 & -3.52 & -1.56 & 0.39 & 2.34 \\
\hline Argon & & 1.07 & -1.47 & 1.49 & 3.61 & 3.19 \\
\hline \multicolumn{7}{|l|}{ Mass Spec \#2 } \\
\hline Hydrogen & & -0.20 & -4.60 & -3.06 & -2.23 & -5.06 \\
\hline Oxygen & & -0.02 & -5.23 & -2.20 & 1.53 & -2.82 \\
\hline \begin{tabular}{|l|} 
Nitrogen \\
\end{tabular} & & 1.53 & -3.17 & -0.29 & 3.20 & -1.03 \\
\hline Carbon Dioxide & & 0.73 & -4.21 & -0.43 & 2.91 & -0.94 \\
\hline Benzene & & 8.20 & -13.67 & -12.50 & -11.72 & -12.50 \\
\hline Argon & & 0.97 & -4.36 & -0.64 & 3.22 & -0.99 \\
\hline
\end{tabular}

The raw calibration data is shown in the upper part of Table 2 and the \%Error off the standard is shown in the lower portion. The \%Error was calculated as:

$\%$ Error $=\frac{(\text { Re ading }- \text { Std })}{S t d} \times 100$

All values were well within the $+/-10 \%$ error range except for the benzene readings on MS\#2. We were unable to correct this within the expected timeframe allowed and accepted that the MS\#2 benzene was within $+/-15 \%$.

Based on the results with the calibration gases, MS\#2 was used for the DMR analyses and MS\#1 was used for the CRR analyses to allow a more accurate reading of benzene leaving the CRR. 
SRNS-STI-2008-00105

Revision 0, 9/25/08

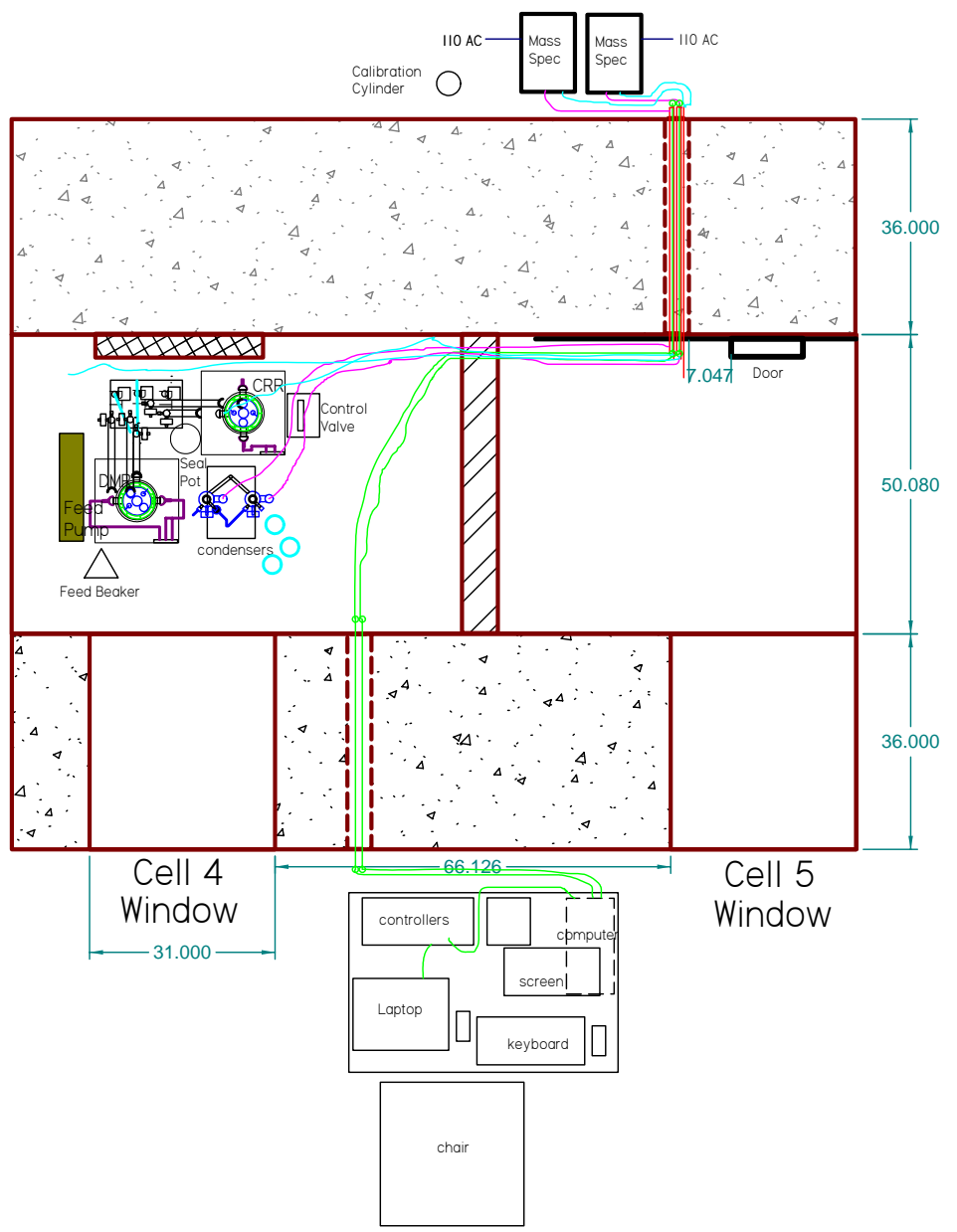

Figure 9. Total System Layout at Cell 4 (Simplified)

The computers for the MS and process control along with the steam water pumps, MKS gas flow controllers, furnace controllers, furnace safety relays, and input/output box were on or below a 30 " $\mathrm{x} 45$ " table situated just to the right of the cell 4 window. The MSs were in a radio-hood behind cell 5. The actual BSR was in cell 4. Connections between process and control systems required the use of 9 inner wall connection tubes (known at SRNL as KAPL plugs which were first developed at Knolles Atomic Power Laboratory).

Cell 3 (not shown) was available for use in performing sample preparatory work and providing space for sample residues until the runs were completed. 


\subsection{BSR OPERATING CONDITIONS FOR ACTUAL TANK 48H WASTE}

Table 3 shows the flows for the 2006 THOR Hazen Tank 48H ESTD FBSR Production Run 4 values from Table 6-1, Table 8-1, and Table 8-2 from the TTT report ${ }^{1}$, the scaled BSR equivalent flows, and the actual flows for both the BSR simulant runs and the BSR Tank48H radioactive runs. The BSR feed rate is the primary parameter for scaling this process to the ESTD FBSR process. After the ESTD FBSR values are scaled down based on the BSR feed rate, the actual operating BSR values were then adjusted due to configuration differences between the ESTD FBSR and BSR.

Table 3. BSR Process Operation Conditions compared to Pilot-Scale FBSR Conditions for Prod-4

\begin{tabular}{|c|c|c|c|c|}
\hline $\begin{array}{l}\text { DMR Feed } \\
\text { Stream }\end{array}$ & FBSR Value & $\begin{array}{c}\text { Scaled Simulant } \\
\text { BSR } \\
\text { DMR Value }\end{array}$ & $\begin{array}{l}\text { Actual Simulant BSR } \\
\text { DMR Operating Value }\end{array}$ & $\begin{array}{c}\text { Actual Radioactive } \\
\text { Tank48H BSR } \\
\text { DMR Operating Value }\end{array}$ \\
\hline $\begin{array}{l}\text { Waste } \\
\text { Slurry }\end{array}$ & $\begin{array}{l}0.21 \mathrm{gpm}(795 \\
\mathrm{ml} / \mathrm{min})\end{array}$ & $1 \mathrm{ml} / \mathrm{min}$ & $1 \mathrm{ml} / \mathrm{min}$ & $1 \mathrm{ml} / \mathrm{min}$ \\
\hline $\begin{array}{l}\text { Waste } \\
\text { Slurry }\end{array}$ & $930 \mathrm{~g} / \mathrm{min}^{\#}$ & $1.17 \mathrm{~g} / \mathrm{min}^{\#}$ & $1.17 \mathrm{~g} / \mathrm{min}^{\#}$ & $1.17 \mathrm{~g} / \mathrm{min}^{\#}$ \\
\hline Carbon* & $\begin{array}{c}12.6 \mathrm{~kg} / \mathrm{hr}(210 \\
\mathrm{g} / \mathrm{min})\end{array}$ & $0.26 \mathrm{~g} / \mathrm{min}$ & $0.20 \mathrm{~g} / \mathrm{min}^{*}$ & $0.20 \mathrm{~g} / \mathrm{min}^{*}$ \\
\hline $\begin{array}{c}\text { Atomizing } \\
\text { Air }\end{array}$ & $\begin{array}{c}\text { 9.85 SCFM (2.79E5 } \\
\text { sccm) }\end{array}$ & $\begin{array}{c}0.0127 \text { SCFM (360 } \\
\text { sccm) }\end{array}$ & $\begin{array}{c}\text { 0-0.035 SCFM }(0-1000 \\
\text { sccm })^{\&} \text { Avg. } 0.011 \\
\text { SCFM }(312 \mathrm{sccm})\end{array}$ & $\begin{array}{c}\text { 0-0.035 SCFM (0-1000 } \\
\text { sccm })^{\&} \text { Avg. } 0.009 \\
\text { SCFM (245 sccm) }\end{array}$ \\
\hline $\begin{array}{c}\text { Fluidizing } \\
\text { Steam }\end{array}$ & $\begin{array}{c}18.6 \mathrm{~kg} / \mathrm{hr}(310 \\
\mathrm{g} / \mathrm{min})\end{array}$ & $0.40 \mathrm{~g} / \mathrm{min}$ & $0.40 \mathrm{~g} / \mathrm{min}$ & $0.40 \mathrm{~g} / \mathrm{min}$ \\
\hline Oxygen $^{\&}$ & $\begin{array}{c}7.7 \text { SCFM (2.18E5 } \\
\text { sccm) }\end{array}$ & $\begin{array}{c}0.0099 \text { SCFM (281 } \\
\text { sccm) }\end{array}$ & $\&$ & $\&$ \\
\hline $\mathrm{CO}_{2}$ & $\begin{array}{c}8 \text { SCFM (2.26E5 } \\
\text { sccm) }\end{array}$ & $\begin{array}{c}0.01 \text { SCFM (292 } \\
\text { sccm) }\end{array}$ & 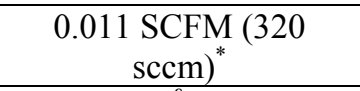 & $\begin{array}{c}0.011 \mathrm{SCFM}^{\text {SCF }}(320 \\
\text { sccm })^{*}\end{array}$ \\
\hline $\mathbf{N}_{2}$ Purges $^{\&}$ & $\begin{array}{c}25.9 \text { SCFM 7.34E5 } \\
\text { sccm) }\end{array}$ & $\begin{array}{c}0.034 \text { SCFM (946 } \\
\text { sccm) }\end{array}$ & $\&$ & $\&$ \\
\hline
\end{tabular}

In the ESTD FBSR, coal was added separately from the feed. For the BSR, the coal was premixed with the feed and both were fed through the top of the unit as a single stream. The same Erwin coal used in the ESTD FBSR, was ground and sieved to 80 mesh (177 microns), then mixed into the Tank $48 \mathrm{H}$ feed for the BSR. A mixture of 60 grams coal to $300 \mathrm{ml}$ of feed produced enough hydrogen in the BSR DMR to allow off-gas control similar to the ESTD FBSR $\mathrm{DMR}^{1}$. The BSR feed rate was set at $1 \mathrm{ml} / \mathrm{min}$ to reduce the amount of carry-over of carbon and other particulates from the DMR. Since the non-radioactive and radioactive BSR systems were identical, the operating parameters determined for the non-radioactive runs were used in the radioactive runs. 
In the ESTD FBSR, oxygen was bled in to provide the heat necessary by consuming $\mathrm{H}_{2}$ and carbon. In the BSR, the heat was added by chemical reaction with oxygen and by an electric furnace to control the temperature to $670^{\circ} \mathrm{C}$ at the control thermocouple point.

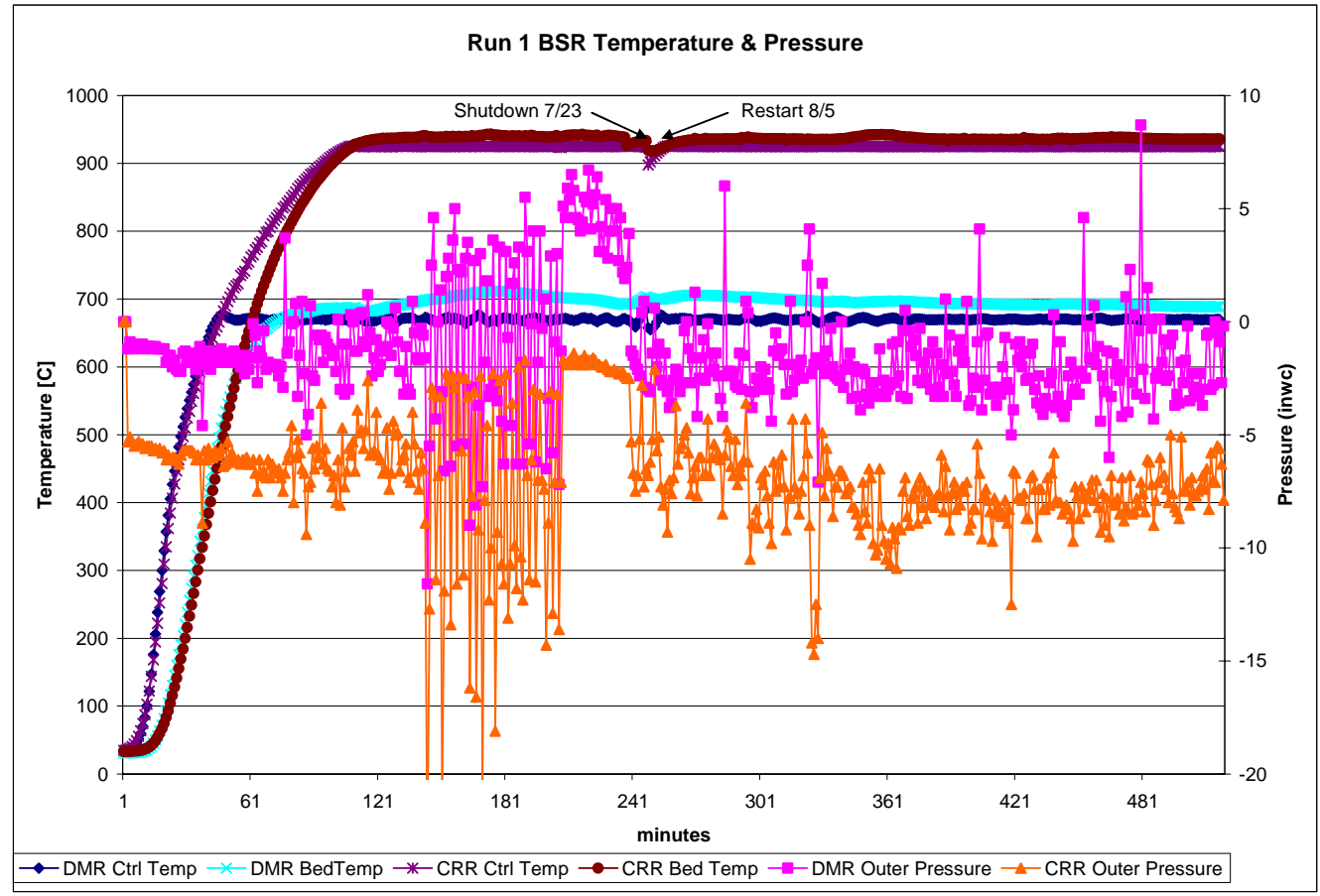

Figure 10. Run 1 BSR Temperature \& Pressure

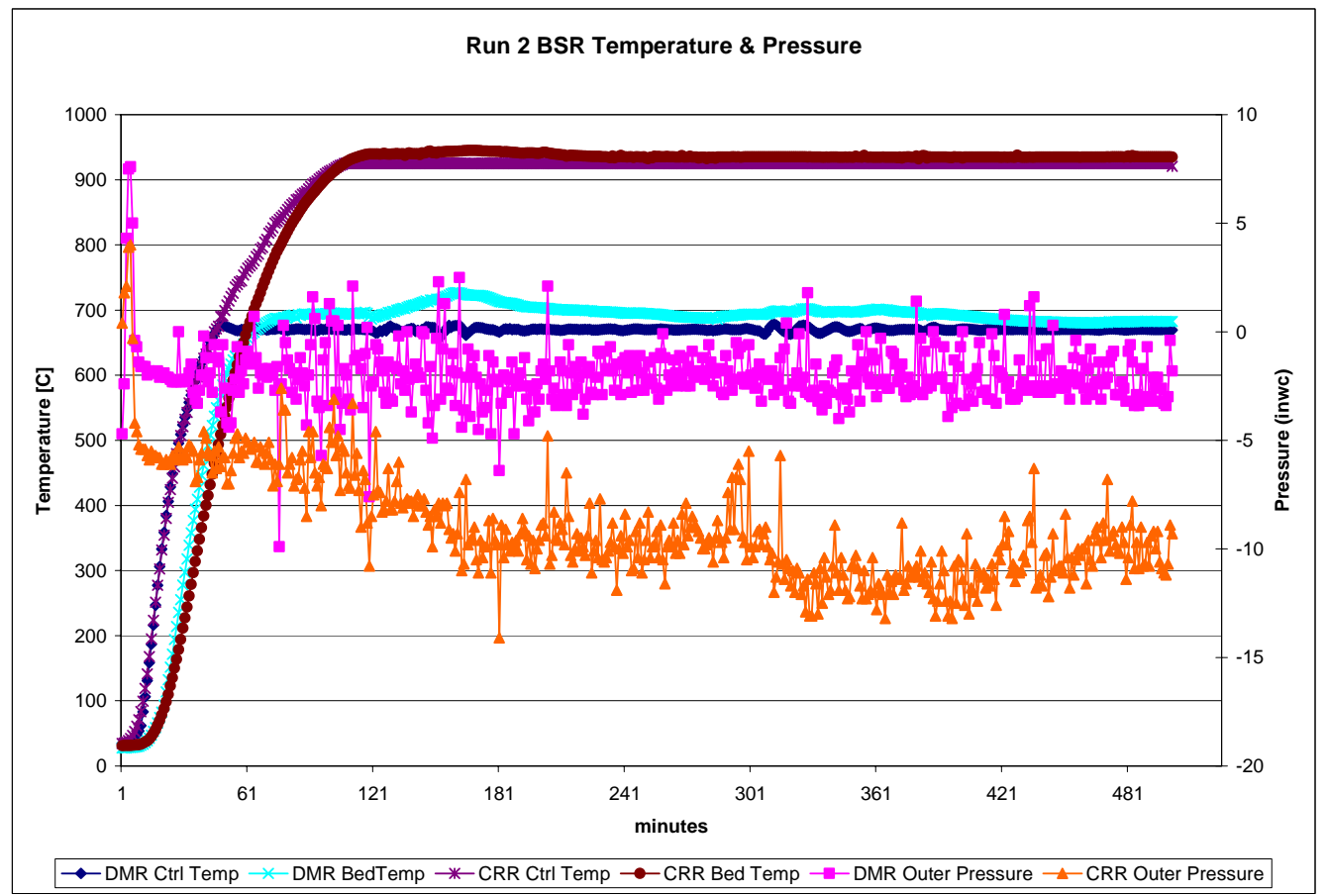

Figure 11. Run 2 BSR Temperature \& Pressure 


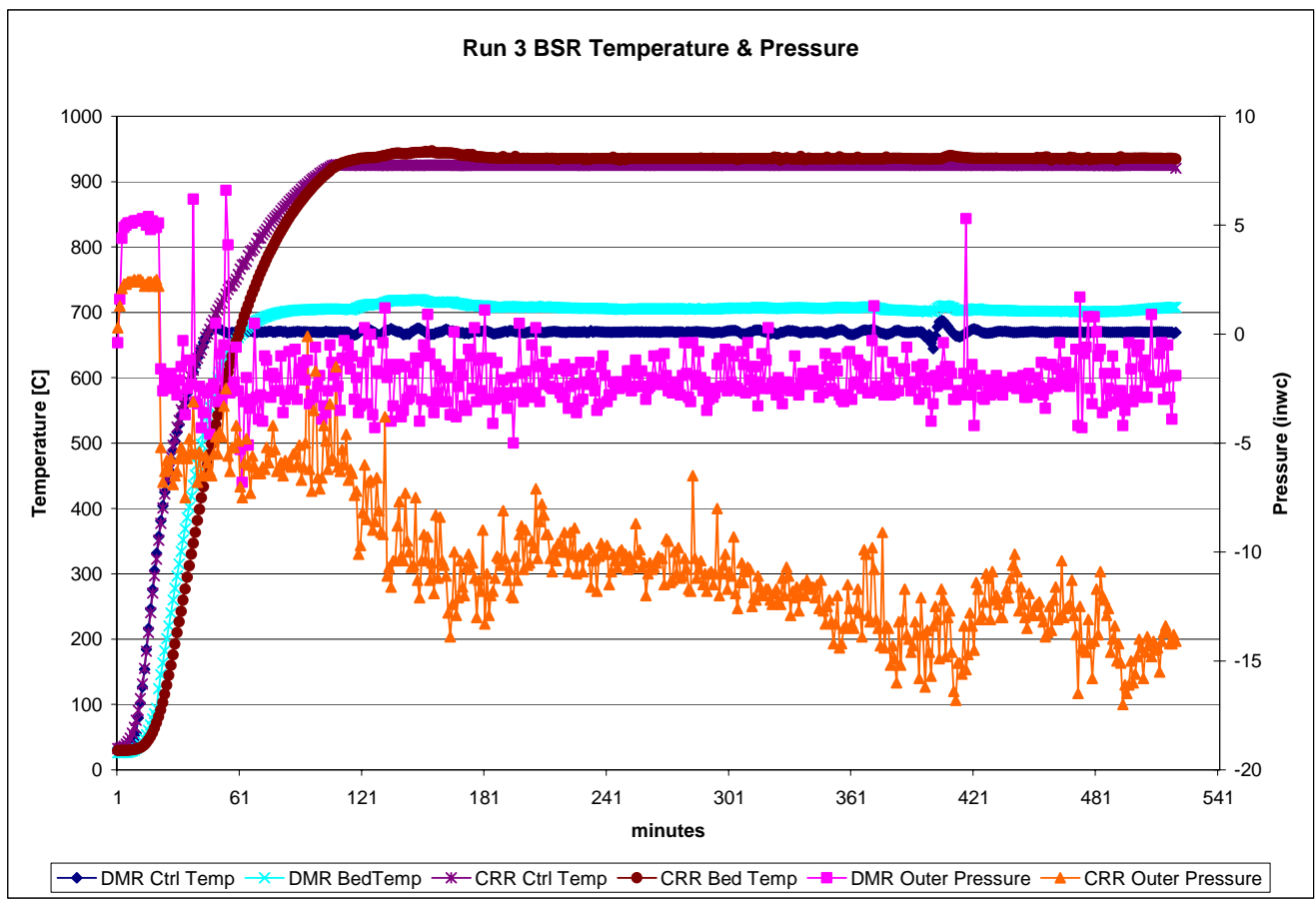

Figure 12. Run 3 BSR Temperature \& Pressure

Temperature control for all runs was within $+/-10^{\circ} \mathrm{C}$ of set-point.

Run 1 had to be shutdown about 240 minutes after startup as seen in the trend in Figure 10. Though the BSR was leak checked prior to placement in the cell, a leak had developed in a CRR side joint where either the water or air enter due to handling while moving it to the cell. The leak caused an excessive amount of air and moisture to flow through the CRR dry ice condenser. The excessive moisture froze to create an excessively small restricting orifice in the dry ice condenser rendering the pressure control system ineffective.

It was remediated by doubling the capacity of the CRR dry ice condenser by adding a second condenser in parallel. However, upon restarting the unit, the leak in the CRR had self sealed itself due to the heat-up and cool-down cycle of the initial run so run 2 and run 3 ran flawlessly as seen in Figure 11 and Figure 12. The reason the joint self sealed was because the metal tubing expands and contracts much more than the quartz so the movement of the tubing pulled the seal back in upon cool down. A small amount of movement was allowed in the design such that the metal tube has some freedom to move through a graphite ferrule within the joint.

During a normal run, the pressure control was expected to maintain the DMR outer pressure to -2 inwc. Runs 2 and 3 met this expectation. The decrease in the CRR outer pressure over time was due to ice forming in the DMR dry ice condenser as expected. The unit would be shut down if the CRR outer pressure decreased to $<-25$ inwc to prevent measurement problems with the MS which ran at -30 inwc. 
SRNS-STI-2008-00105

Revision 0, 9/25/08

Table 4. DMR Mass Spectrometer Off-gas Measurement Summary Data (vol\%)

\begin{tabular}{|c|c|c|c|c|c|c|c|c|c|c|c|c|c|c|c|c|c|c|}
\hline & \multicolumn{3}{|c|}{$\mathrm{DMR} \mathrm{H}_{2}$} & \multicolumn{3}{|c|}{$\mathrm{DMR} \mathrm{O}_{2}$} & \multicolumn{3}{|c|}{ DMR N $_{2}$} & \multicolumn{3}{|c|}{$\mathrm{DMR} \mathrm{CO}_{2}$} & \multicolumn{3}{|c|}{ DMR Benzene } & \multicolumn{3}{|c|}{ DMR Argon } \\
\hline $\begin{array}{l}\text { Rad } \\
\text { Run }\end{array}$ & Min & Max & Avg & Min & Max & Avg & Min & Max & Avg & Min & Max & Avg & Min & Max & Avg & Min & Max & Avg \\
\hline 1 & 1.5 & 8.96 & 2.06 & 0.33 & 20.66 & 4.45 & 12.29 & 76.40 & 40.12 & 0.43 & 75.75 & 48.18 & 0.00 & 0.30 & 0.04 & 0.13 & 0.90 & 0.47 \\
\hline 2 & 1.0 & 7.13 & 2.64 & 0.43 & 9.78 & 5.40 & 3.72 & 53.20 & 45.39 & 21.06 & 83.06 & 32.82 & 0.03 & 0.50 & 0.09 & 0.05 & 0.60 & 0.51 \\
\hline 3 & 1.0 & 8.98 & 2.59 & 0.60 & 10.68 & 5.51 & 3.01 & 56.71 & 46.91 & 20.31 & 90.94 & 34.04 & 0.02 & 0.37 & 0.08 & 0.04 & 0.64 & 0.53 \\
\hline
\end{tabular}

Table 5. CRR Mass Spectrometer Off-gas Measurement Summary Data (vol\%)

\begin{tabular}{|c|c|c|c|c|c|c|c|c|c|c|c|c|c|c|c|c|c|c|}
\hline & \multicolumn{3}{|c|}{$\mathrm{CRR} \mathrm{H}_{2}$} & \multicolumn{3}{|c|}{$\mathrm{CRR} \mathrm{O}_{2}$} & \multicolumn{3}{|c|}{$\mathrm{CRR} \mathrm{N}_{2}$} & \multicolumn{3}{|c|}{$\mathrm{CRR} \mathrm{CO}_{2}$} & \multicolumn{3}{|c|}{ CRR Benzene } & \multicolumn{3}{|c|}{ CRR Argon } \\
\hline $\begin{array}{l}\text { Rad } \\
\text { Run }\end{array}$ & Min & Max & Avg & Min & Max & Avg & Min & Max & Avg & Min & Max & Avg & Min & Max & Avg & Min & Max & Avg \\
\hline 1 & 0.02 & 0.04 & 0.03 & 9.37 & 19.94 & 14.38 & 44.17 & 75.53 & 62.66 & 0.12 & 40.44 & 14.66 & 0.00 & 0.01 & 0.00 & 0.52 & 0.89 & 0.72 \\
\hline 2 & 0.02 & 0.04 & 0.02 & 4.63 & 12.41 & 9.76 & 43.52 & 62.11 & 58.35 & 13.67 & 38.33 & 20.64 & 0.00 & 0.00 & 0.00 & 0.50 & 0.71 & 0.67 \\
\hline 3 & 0.02 & 0.04 & 0.02 & 4.35 & 14.00 & 10.25 & 39.68 & 65.28 & 60.02 & 11.48 & 44.34 & 20.95 & 0.00 & 0.00 & 0.00 & 0.45 & 0.73 & 0.69 \\
\hline
\end{tabular}

The BSR used a DMR air supply $\left(78 \% \mathrm{~N}_{2} / 21 \% \mathrm{O}_{2}\right)$ to control the DMR $\mathrm{H}_{2}$ concentration so the $\mathrm{N}_{2}$ and $\mathrm{O}_{2}$ flows were determined by the air flow rate. The BSR air flow rate was varied from 0 to $1000 \mathrm{sccm}$ (standard cubic centimeters per minute) with an average air flow of $245 \mathrm{sccm}$ to control the volume $\%$ of $\mathrm{H}_{2}$ between $1.5 \%$ and $4.0 \%$. Table 4 shows the DMR $\mathrm{H}_{2}$ vol\% goes through ranges from about $1.0 \mathrm{vol} \%$ to $9 \mathrm{vol} \%$. This variance is due to the fact that the $\mathrm{H}_{2} \mathrm{vol} \%$ is being manually controlled by the amount of air fed into the DMR and the mass spectrometer reading lags 1-2 minutes behind. Overall these variances have minimal impact as evidenced by the average DMR hydrogen rates from 2.06\% to 2.64\%. (Also see Figure 14, Figure 16, and Figure 18)

Comparing Table 4 to Table 5 shows that the destruction of $\mathrm{H}_{2}$ and benzene in the CRR was virtually completed. For the $\mathrm{H}_{2}$, the concentration entering the CRR averaged up to $2.64 \mathrm{vol} \%$ where the highest average concentration leaving the CRR was 0.03 vol\%. For benzene, the concentration entering the CRR averaged up to $900 \mathrm{ppm}$ where the highest average concentration leaving the CRR was 0 ppm. These off-gas measurements compare well with those from the HRI testing ${ }^{1}$ in 2006 where the stack gas after the CRR had on average $0.00 \%$ of total hydrocarbons (keeping in mind that they used a flame total hydrocarbon analyzer).

Figure 13 through Figure 21 show the trends of the MS off-gas measurements for the DMR and CRR for the three consecutive radioactive BSR runs. 
SRNS-STI-2008-00105

Revision 0, 9/25/08

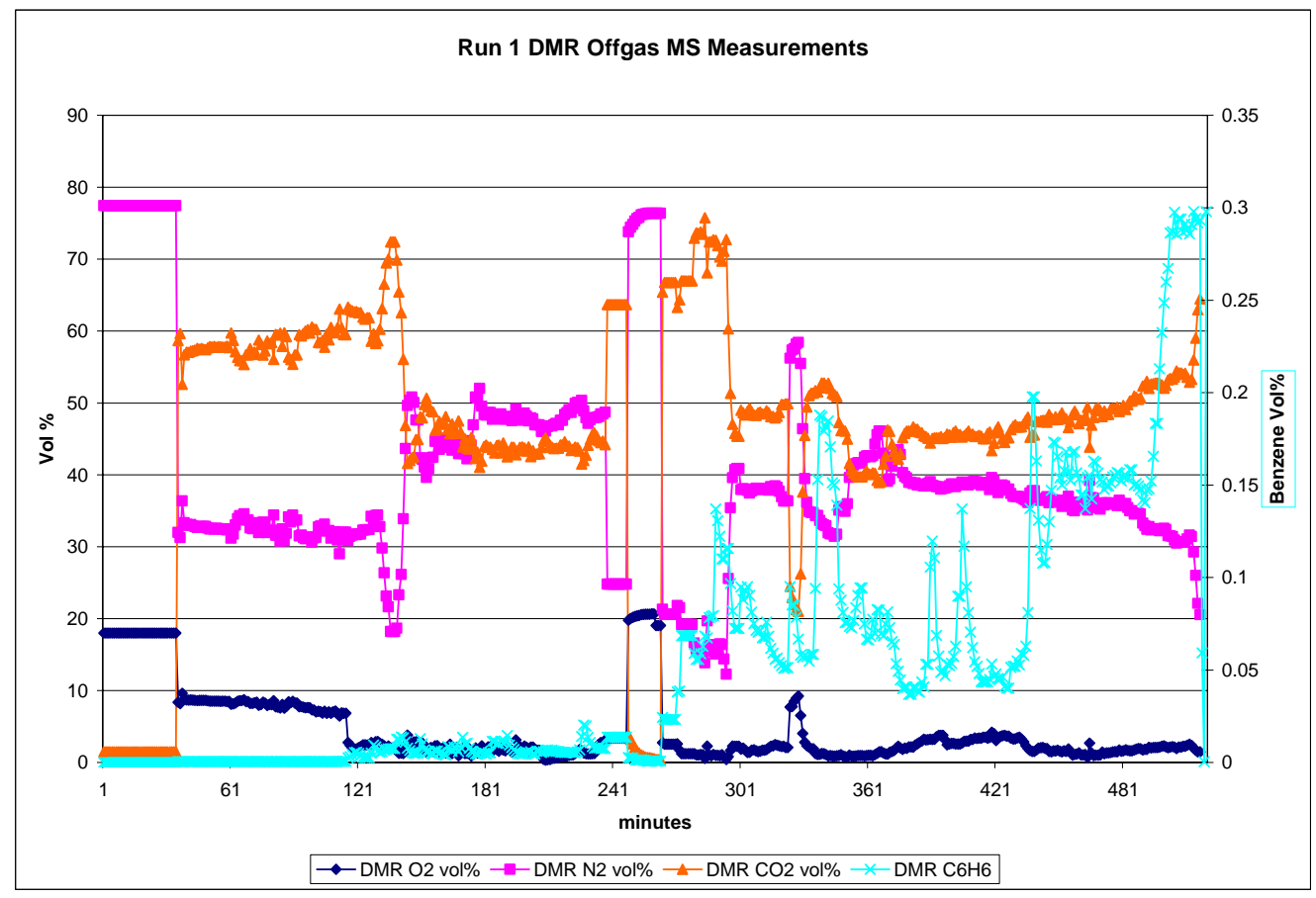

Figure 13. Run 1 DMR Off-gas Measurements

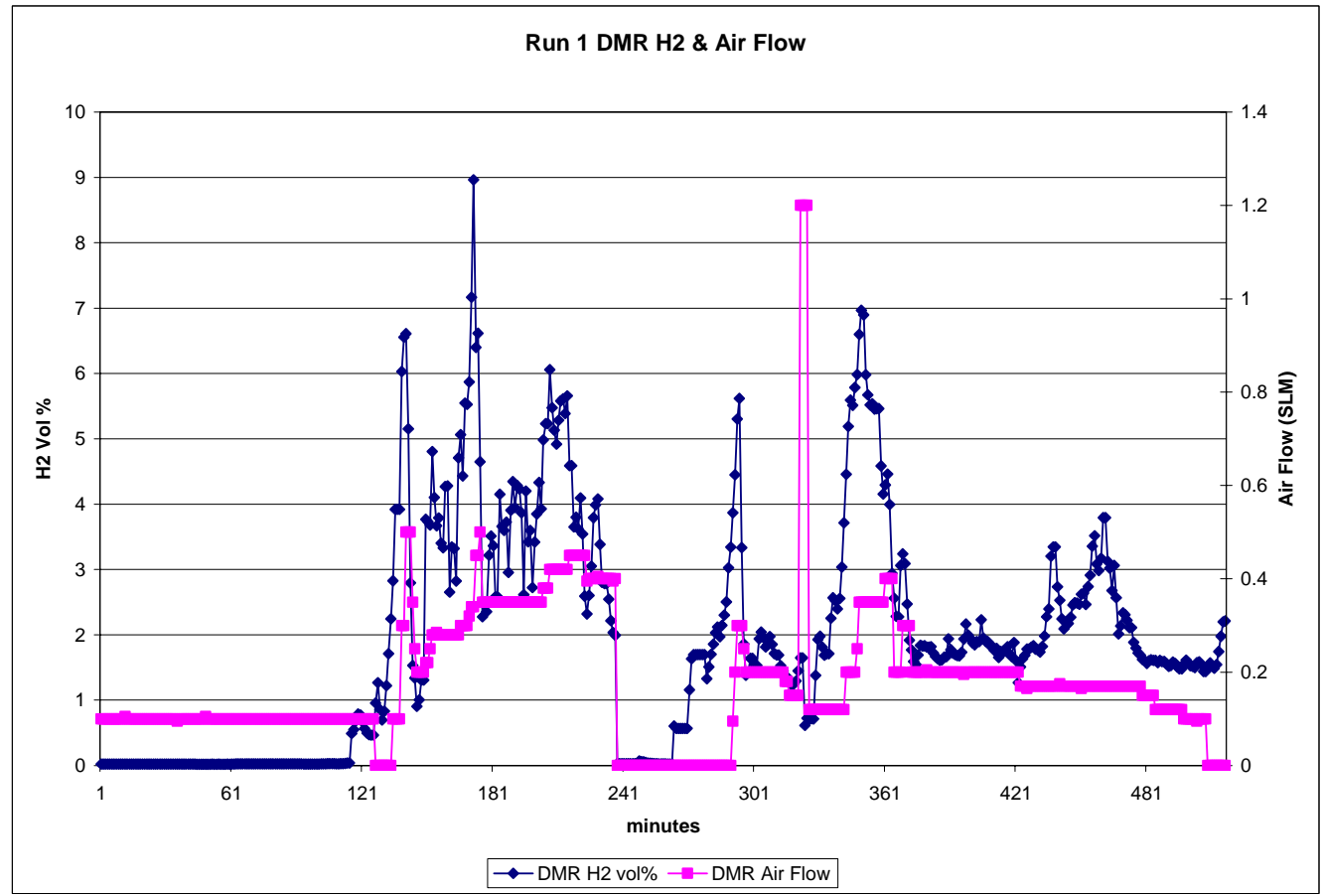

Figure 14. Run 1 DMR Off-gas $\mathrm{H}_{2}$ \& Air Flow 
SRNS-STI-2008-00105

Revision 0, 9/25/08

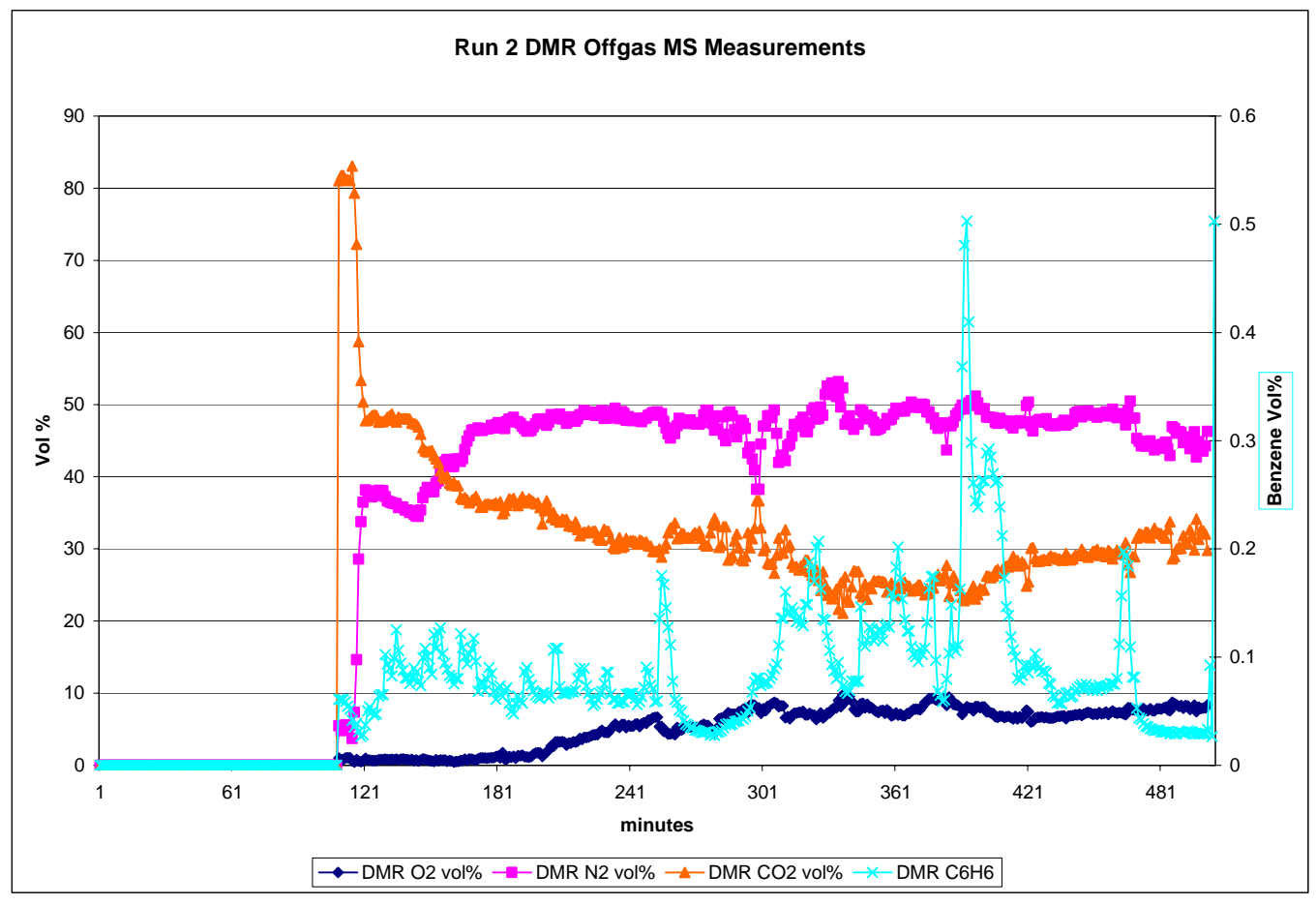

Figure 15. Run 2 DMR Off-gas Measurements

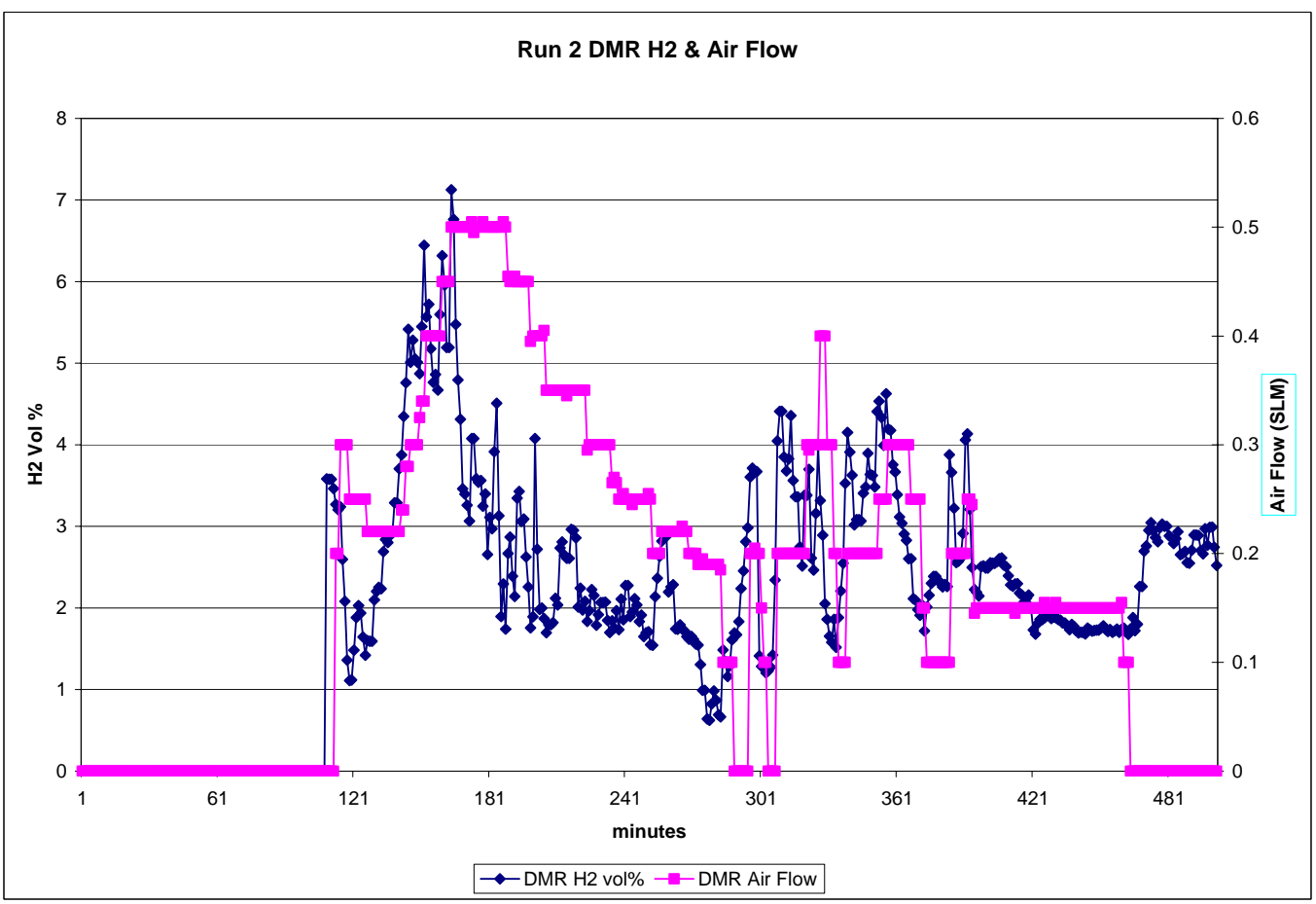

Figure 16. Run 2 DMR Off-gas $\mathrm{H}_{2}$ \& Air Flow 
SRNS-STI-2008-00105

Revision 0, 9/25/08

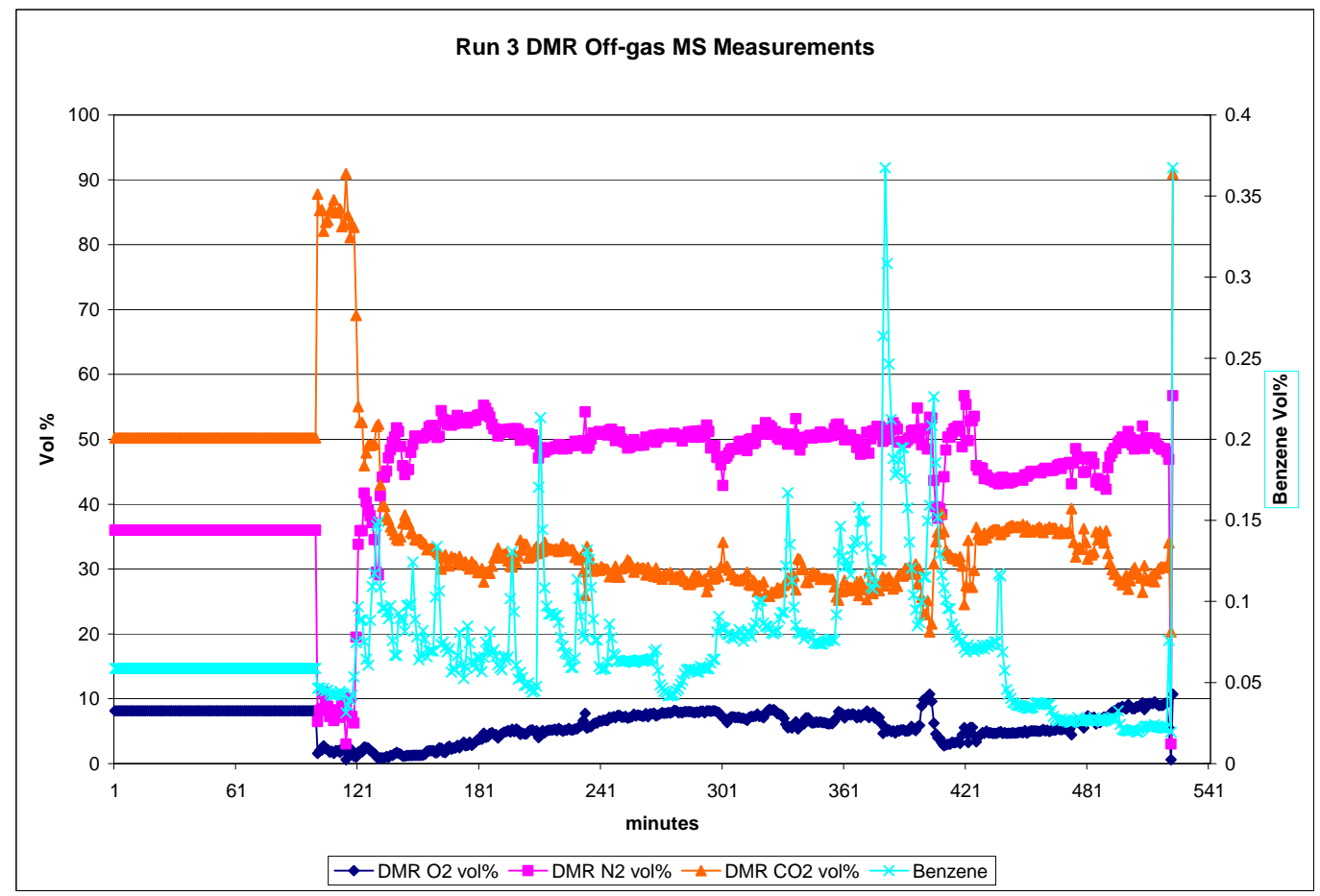

Figure 17. Run 3 DMR Off-gas Measurements

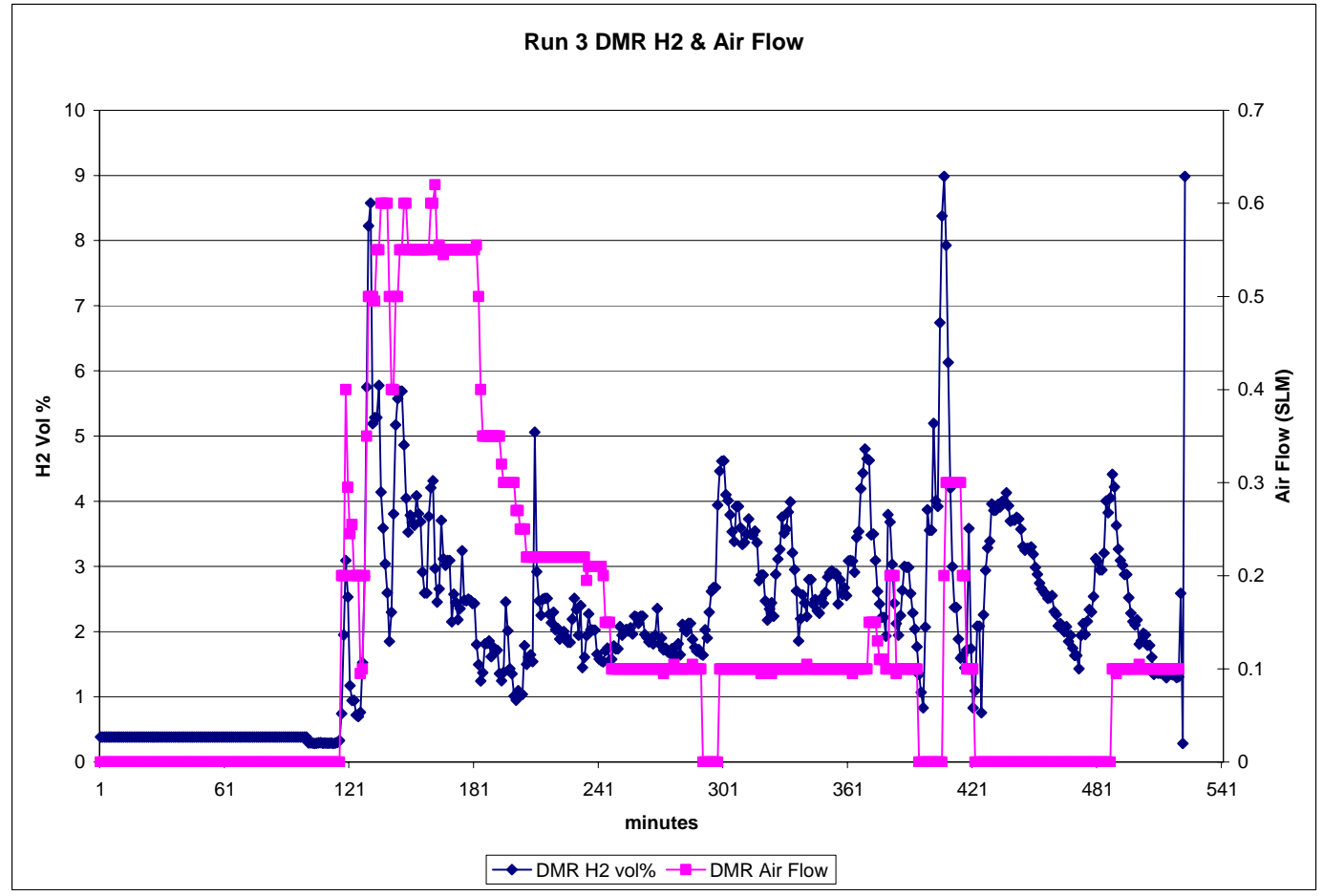

Figure 18. Run 3 DMR Off-gas $\mathrm{H}_{2}$ \& Air Flow 
SRNS-STI-2008-00105

Revision 0, 9/25/08

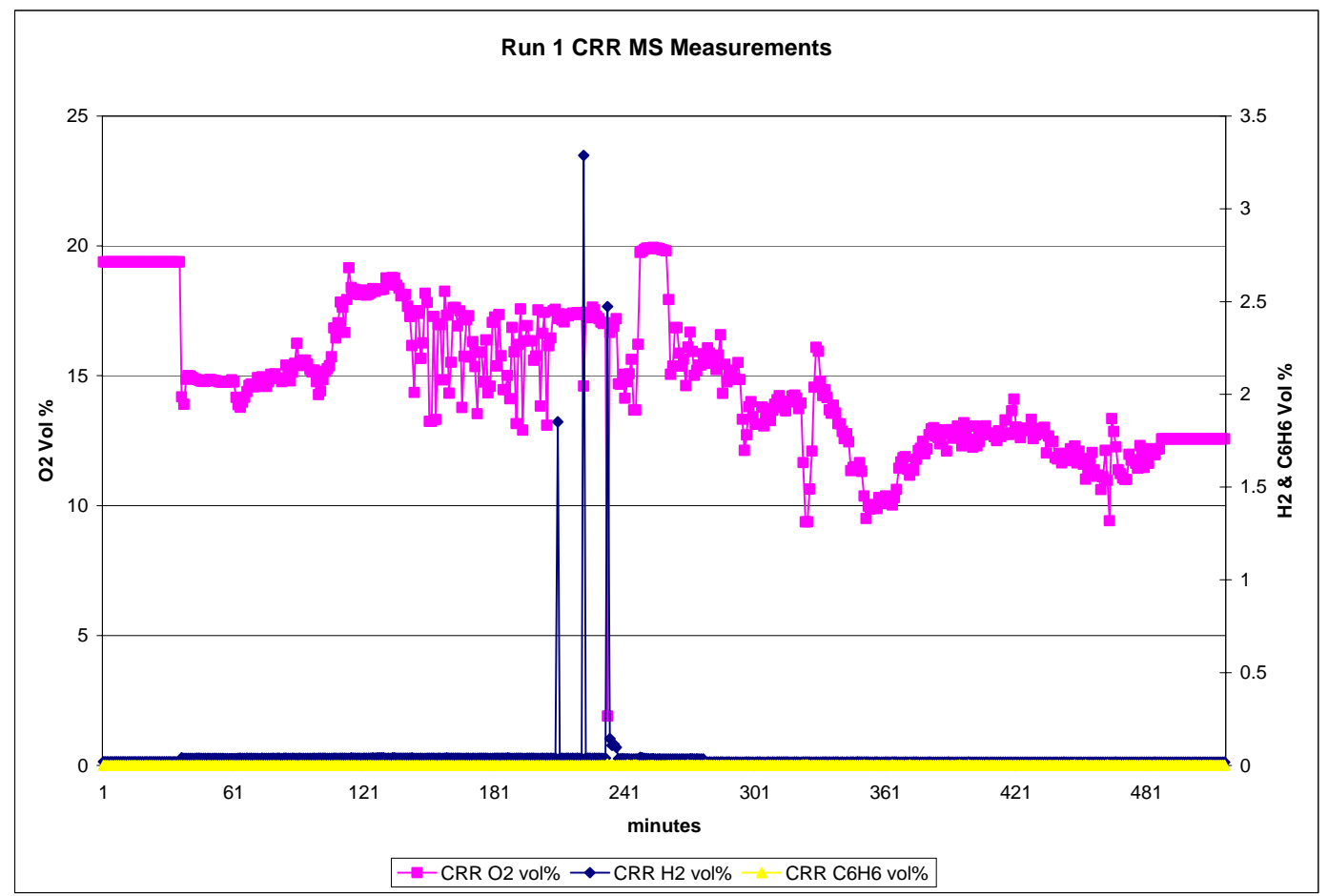

Figure 19. Run 1 CRR Off-gas MS Measurements

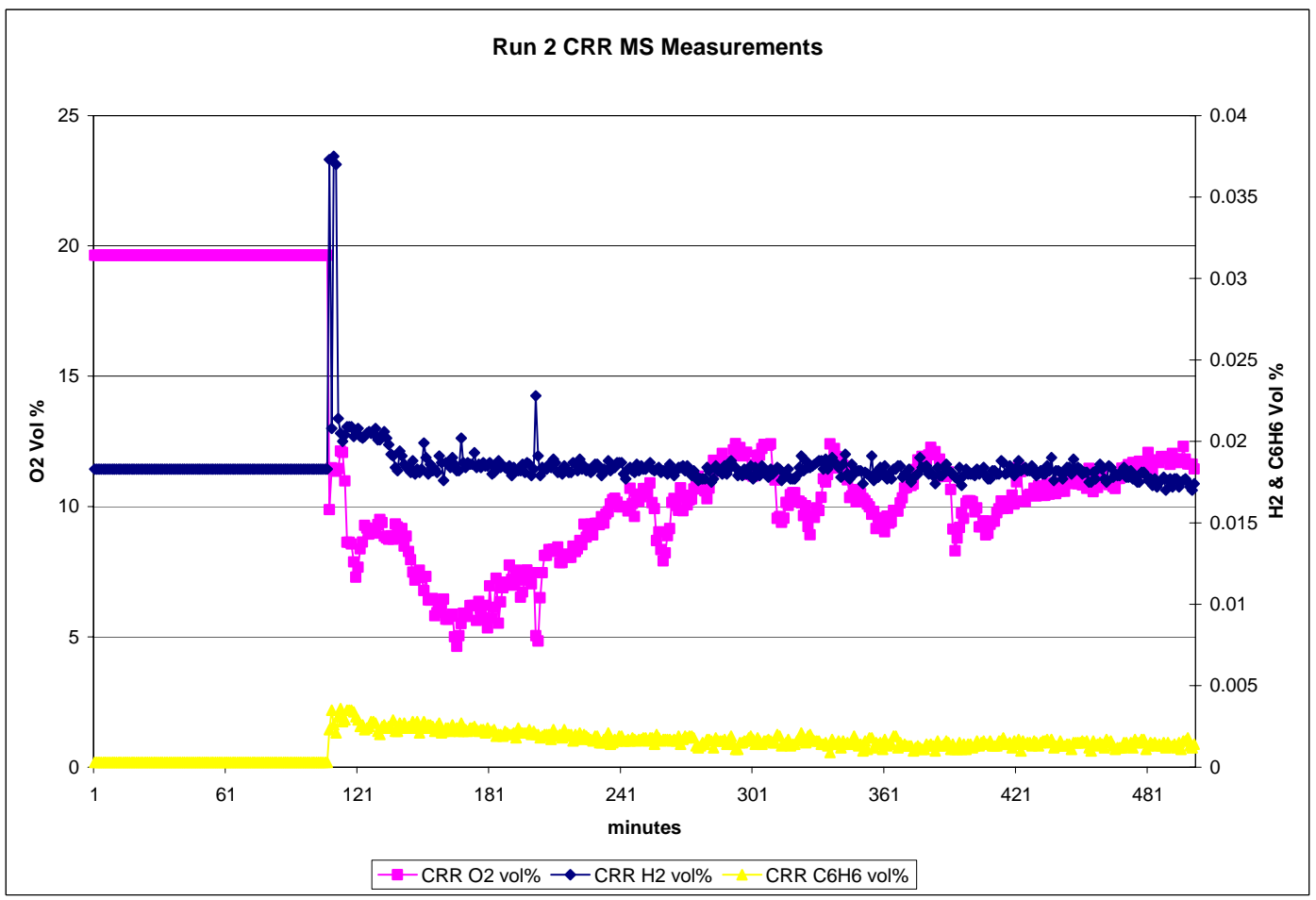

Figure 20. Run 2 CRR Offgas MS Measurements 
SRNS-STI-2008-00105

Revision 0, 9/25/08

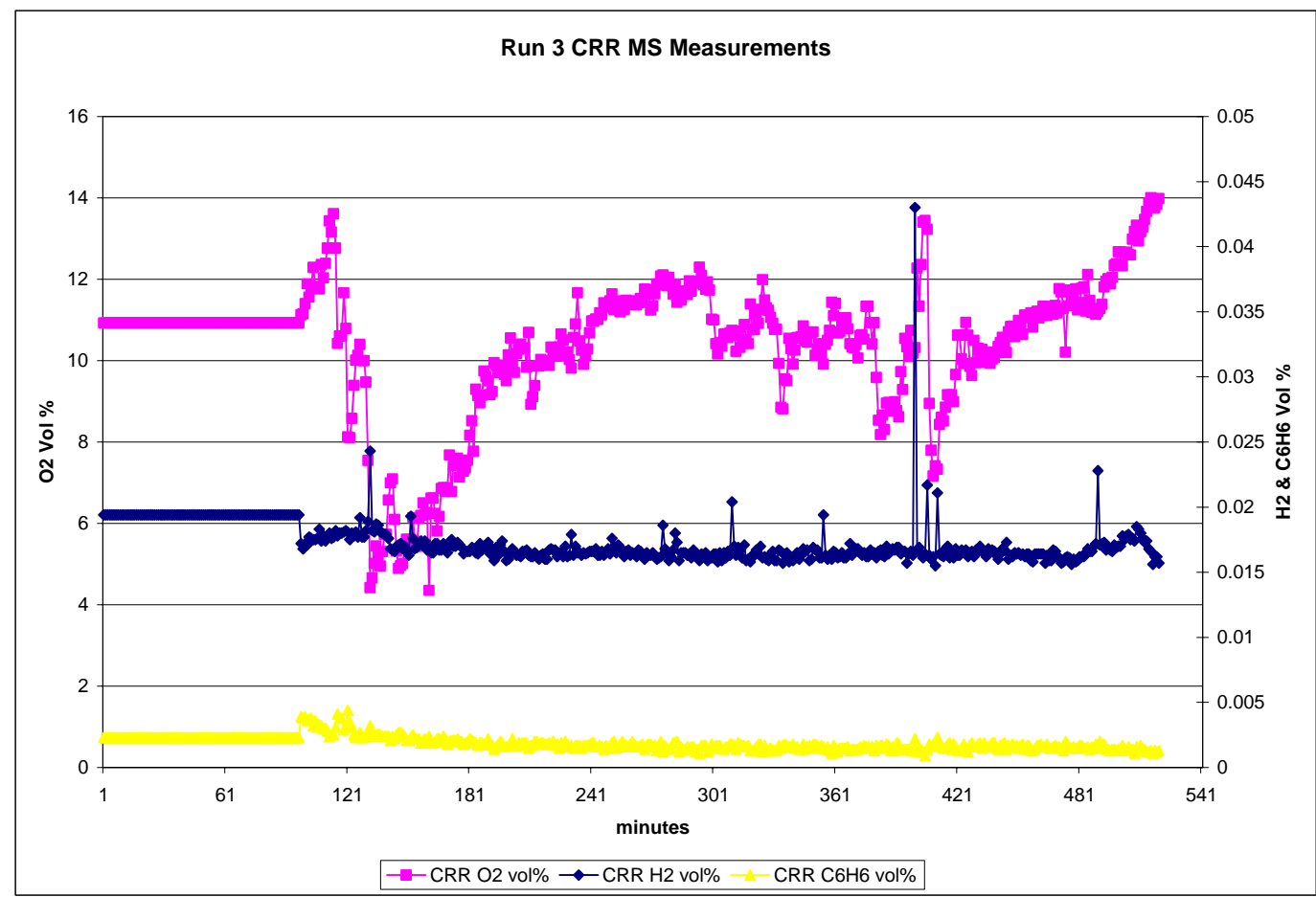

Figure 21. Run 3 CRR Offgas MS Measurements

Not shown on Figure 13 through Figure 21 above are the DMR $\mathrm{CO}_{2}$ flow rate which flowed at a constant $321 \mathrm{sccm}$, the CRR air flow rate which flowed at a constant $400 \mathrm{sccm}$, and the vol\% argon since it was no longer used as a blanket gas.

The DMR off-gas showed evidence of benzene with average values from $0.04 \%$ to $0.09 \%$ on a dry basis. A certain amount of benzene is expected in the DMR off-gas as the HRI testing ${ }^{1}$ in 2006 showed an average about 0.18 vol\% benzene on a wet basis.

Sufficient air $\left(\mathrm{O}_{2}\right)$ was added to the CRR to destroy any oxidizable species as evidenced by the lack of $\mathrm{H}_{2}$ and benzene; and since the $\mathrm{O}_{2}$ level never dropped below 4\%. However, it would be prudent to raise the air flow rate to the CRR in future tests such that the $\mathrm{O}_{2}$ concentration never drops below $10 \%$. 


\subsection{ANALYSIS \& OBSERVATIONS}

\subsection{ANALYSIS OF TANK 48H WASTE}

Radioactive Tank 48H samples were obtained from a 3.0 L composite located in the shielded cells facility. Table 6 and Table 7 show characterization data for the radioactive sample that was obtained and analyzed in $2005 .^{6}$

Table 6. Radioactive Tank 48H Data of HTF-E-05-021 Slurry Sample ${ }^{6}$

\begin{tabular}{|c|c|c|c|}
\hline $\begin{array}{l}\text { Tank 48H } \\
\text { Radioactive }\end{array}$ & & & \\
\hline Component & $(\mathrm{mg} / \mathrm{L})$ & Component & $(\mathrm{mg} / \mathrm{L})$ \\
\hline $\mathrm{Al}$ & 2014 & $\mathrm{Sn}$ & $<0.11$ \\
\hline $\mathrm{B}$ & 867 & $\mathrm{Sr}$ & 9 \\
\hline $\mathrm{Ba}$ & $<0.008$ & $\mathrm{Ti}$ & 826 \\
\hline $\mathrm{Ca}$ & 43 & $\mathrm{U}$ & 7 \\
\hline $\mathrm{Cd}$ & $<0.017$ & $\mathrm{~V}$ & $<0.007$ \\
\hline $\mathrm{Ce}$ & 5 & $\mathrm{Zn}$ & 5 \\
\hline $\mathrm{Cr}$ & 70 & $\mathrm{Zr}$ & 1.47 \\
\hline $\mathrm{Cu}$ & 4 & $\mathrm{~F}$ & 14 \\
\hline $\mathrm{Fe}$ & 169 & $\mathrm{Cl}$ & 172 \\
\hline $\mathrm{K}$ & 5155 & $\mathrm{NO} 2$ & 23750 \\
\hline $\mathrm{La}$ & $<0.032$ & $\mathrm{NO} 3$ & 14250 \\
\hline $\mathrm{Mg}$ & 19 & $\mathrm{SO} 4$ & 323 \\
\hline $\mathrm{Mn}$ & 6 & $\mathrm{PO} 4$ & 428 \\
\hline Mo & $<0.053$ & $\mathrm{wt} \%$ Total solids & 20.19 \\
\hline $\mathrm{Na}$ & 87899 & $\begin{array}{c}\mathrm{wt} \% \text { Insoluble } \\
\text { solids } \\
\end{array}$ & 3.05 \\
\hline $\mathrm{Ni}$ & $<0.015$ & $\mathrm{wt} \%$ Soluble solids & 17.14 \\
\hline $\mathrm{P}$ & 129 & $\mathrm{pH}$ & 14 \\
\hline $\mathrm{Pb}$ & $<0.283$ & Density $(\mathrm{g} / \mathrm{mL})$ & 1.14 \\
\hline $\mathrm{S}$ & 378 & & \\
\hline $\mathrm{Si}$ & 125 & & \\
\hline
\end{tabular}


SRNS-STI-2008-00105

Revision 0, 9/25/08

Table 7. The High Pressure Liquid Chromotography (HPLC) results of HTF-E-05-021 T48 Slurry Sample ${ }^{6}$

\begin{tabular}{|l|l|l|}
\hline Analyte & $\begin{array}{l}\text { Concentration, } \\
(\mathrm{mg} / \text { L slurry })\end{array}$ & $\begin{array}{l}\text { St. Dev, } \\
(\mathrm{mg} / \mathrm{L})\end{array}$ \\
\hline TPB Anion & 21,000 & 970 \\
\hline Calculated KTPB & 23796 & - \\
\hline 3PB & 74 & 16.5 \\
\hline 2PB & 142 & 19 \\
\hline 1PB & 151 & 7.6 \\
\hline Phenol & 771 & 22 \\
\hline Biphenyl & 420 & 54.3 \\
\hline
\end{tabular}

\subsection{ANALYSIS OF SOLID DMR PRODUCT}

\subsubsection{Sample Preparation}

The bottom 4 inches of product in the DMR basket were separated from the remainder of the DMR product and analyzed separately since this portion of the product was in the proper reactor heat zone as shown in Figure 3. The upper portions of the product were analyzed as well, but are not discussed since the process conditions for this portion of the product are unknown.

Each sample of solid product was first ground and sieved. A mortar and pestle was used for grinding, and all sample material outside of the zirconium dioxide beads was ground to pass a \#20 sieve. The beads were manually removed from the sample material as soon as they were free of the product that was clinging to them.

The ground solid product was put in sample jars, capped, and agitated to homogenize the powder. Samples of each DMR product were taken out and sent for XRD, REDOX, and HPLC analyses. A separate sample of solids was weighed out for water dissolution. This sample was added to a bottle of deionized water in the ratio of 1 gram of solids per $100 \mathrm{~mL}$ of water. A magnetic stir bar was added to the bottle and stirring was provided for at least 2 hours at ambient temperature.

All of the slurry resulting from the water dissolution was passed through a 0.45 micron filter pad using laboratory vacuum. All insoluble solids were collected and air dried. Weight of the insoluble sample was recorded and the sample was sent to the Analytical Development Dept. (ADD) for XRD. The weight of the insoluble solids could then be subtracted from the input weight to indicate the amount of soluble material in the DMR product. Filtrate was submitted for cation analyses by Inductively Coupled PlasmaEmission Spectroscopy (ICP-ES) and for anion analysis by Ion-Chromotography (IC) anions. 
SRNS-STI-2008-00105

Revision 0, 9/25/08

\subsubsection{Sample Analyses}

Table 8. Mass of DMR Products

\begin{tabular}{|c|c|c|c|}
\hline & Run 1 & Run 2 & Run 3 \\
\hline DMR Mass Total, g & 67.85 & 88.84 & 70.73 \\
\hline Wt\% Insoluble & 4.0 & 5.5 & 10.9 \\
\hline
\end{tabular}

The mass reported is of the total product in the DMR. The wt $\%$ insoluble solid was largely due to un-burnt coal and coal ash. Run 1 had less coal because it was run longer and in two parts due to unrelated process problems with the CRR dry ice condenser. Run 3 had more coal because the unit was off center which caused the product to form along the wall. The lack of air diffusion to the product along the wall probably contributed to the slower burning of coal. The actual mass of carbonate product was less than 70 grams per run, but that value will be used conservatively to show various criteria were met.

Table 9. DMR Product HPLC Analyses for Organics

\begin{tabular}{|l|c|c|c|}
\hline DMR HPLC (mg/kg) & Run 1 & Run 2 & Run 3 \\
\hline TPB Anion & $<5$. & $<5$. & $<5$. \\
\hline 3PB & $<5$. & $<5$. & $<5$. \\
\hline 2PB & $<5$. & $<5$. & $<5$. \\
\hline PBA & $<5$. & $<5$. & $<5$. \\
\hline Phenol & $<5$. & $<5$. & $<5$. \\
\hline Biphenyl & $<5$. & & $<$ \\
\hline
\end{tabular}

The feed TPB anion concentration showed $21000 \mathrm{mg} / \mathrm{L}$ in Table $7.300 \mathrm{ml}$ of feed were fed per run. All runs show less than the detection limit of $5 \mathrm{mg} / \mathrm{kg}$ TPB in the estimated 70 grams of product. Therefore the TPB destruction calculates to:

$300 \mathrm{ml} \_$feed $\times \frac{21000 \mathrm{mg} \_T P B}{1000 \mathrm{ml}}=6300 \mathrm{mg} \_$TPB_Fed

$70 g_{-}$Product $\times \frac{5 \mathrm{mg} \_ \text {TPB }}{\mathrm{kg} g_{-} \text {product }} \times \frac{\mathrm{kg}}{1000 \mathrm{~g}} \leq 0.35 \mathrm{mg} \_$TPB_Product

$\frac{6300-0.35}{6300} \times 100 \geq 99.99 \%$ destruction of TPB.

$99.99 \%$ is greater than the required minimum of $99.9 \%$. Since the Tank 48 feed is subjected to the DMR operating temperature above $600^{\circ} \mathrm{C}$, no organic, including TPB salts and its by-products in the feed are expected to remain with the FBSR product that may contribute to the Tank Farm receipt tank CLFL at $100^{\circ} \mathrm{C}$. 
SRNS-STI-2008-00105

Revision 0, 9/25/08

Table 10. DMR and Insoluble Phase Analysis by X-Ray Diffraction (XRD)

\begin{tabular}{|c|c|c|c|}
\hline & Run 1 & Run 2 & Run 3 \\
\hline \multicolumn{4}{|l|}{ XRD DMR } \\
\hline & $\mathrm{Na}_{2} \mathrm{CO}_{3} \cdot \mathrm{H}_{2} \mathrm{O}$ & $\mathrm{Na}_{2} \mathrm{CO}_{3} \cdot \mathrm{H}_{2} \mathrm{O}$ & $\mathrm{Na}_{2} \mathrm{CO}_{3} \cdot \mathrm{H}_{2} \mathrm{O}$ \\
\hline & $\mathrm{Na}_{2} \mathrm{CO}_{3}$ & $\mathrm{Na}_{2} \mathrm{CO}_{3}$ & $\mathrm{Na}_{2} \mathrm{CO}_{3}$ \\
\hline & $\mathrm{Na}_{3} \mathrm{H}\left(\mathrm{CO}_{3}\right)_{2} \cdot 2 \mathrm{H}_{2} \mathrm{O}$ & & $\mathrm{Na}_{3} \mathrm{H}\left(\mathrm{CO}_{3}\right)_{2} .2 \mathrm{H}_{2} \mathrm{O}$ \\
\hline & $\mathrm{Na}_{8}\left(\mathrm{AlSiO}_{4}\right)_{6}(\mathrm{OH})_{2} \bullet 2 \mathrm{H}_{2} \mathrm{O}$ & $\mathrm{Na}_{8}\left(\mathrm{AlSiO}_{4}\right)_{6}(\mathrm{OH})_{2} \bullet 2 \mathrm{H}_{2} \mathrm{O}$ & $\mathrm{Na}_{8}\left(\mathrm{AlSiO}_{4}\right)_{6}(\mathrm{OH})_{2} \bullet 2 \mathrm{H}_{2} \mathrm{O}$ \\
\hline & $\mathrm{Na}_{2} \mathrm{Al}_{2} \mathrm{SiO}_{6}$ & & $\mathrm{Na}_{2} \mathrm{Al}_{2} \mathrm{SiO}_{6}$ \\
\hline \multicolumn{4}{|c|}{ XRD INSOLUBLES } \\
\hline & $\mathrm{Na}_{8}\left(\mathrm{AlSiO}_{4}\right)_{6}(\mathrm{OH})_{2} \bullet 2 \mathrm{H}_{2} \mathrm{O}$ & $\mathrm{Na}_{8}\left(\mathrm{AlSiO}_{4}\right)_{6}(\mathrm{OH})_{2} \bullet 2 \mathrm{H}_{2} \mathrm{O}$ & $\mathrm{Na}_{8}\left(\mathrm{AlSiO}_{4}\right)_{6}(\mathrm{OH})_{2} \bullet 2 \mathrm{H}_{2} \mathrm{O}$ \\
\hline & $\mathrm{Na}_{0.75} \mathrm{~K}_{0.24} \mathrm{Al}_{0.95} \mathrm{Fe}_{0.13} \mathrm{Si}_{0.77} \mathrm{O}_{4}$ & $\mathrm{Na}_{0.75} \mathrm{~K}_{1.5} \mathrm{Al}_{0.89} \mathrm{Si}_{1.11} \mathrm{O}_{4}$ & $\mathrm{Na}_{0.75} \mathrm{~K}_{1.5} \mathrm{Al}_{0.89} \mathrm{Si}_{1.11} \mathrm{O}_{4}$ \\
\hline & $\mathrm{NaFeTiO}_{4}$ & $\mathrm{NaFeTiO}_{4}$ & $\mathrm{NaFeTiO}_{4}$ \\
\hline & Muscovite aluminosilicate & & $\mathrm{SiO}_{2}$ \\
\hline
\end{tabular}

The DMR product was primarily made up of soluble carbonates. The three most abundant species were thermonatrite, $\left[\mathrm{Na}_{2} \mathrm{CO}_{3} \cdot \mathrm{H}_{2} \mathrm{O}\right]$, sodium carbonate, $\left[\mathrm{Na}_{2} \mathrm{CO}_{3}\right]$, and trona, $\left[\mathrm{Na}_{3} \mathrm{H}\left(\mathrm{CO}_{3}\right)_{2} \cdot 2 \mathrm{H}_{2} \mathrm{O}\right]$. It is thought that the minor amount of silicates and aluminosilicates $\left(\mathrm{Na}_{8}\left(\mathrm{AlSiO}_{4}\right)_{6}(\mathrm{OH})_{2} \bullet 2 \mathrm{H}_{2} \mathrm{O}\right.$ which is hydroxysodalite, nepheline, muscovite and $\left.\mathrm{SiO}_{2}\right)$ may have come from the coal ash and/or the $\mathrm{Si}$ and $\mathrm{Al}$ in the waste (Table 6). See APPENDIX 1 for XRD graphs of products and the insoluble portion of the products.

Table 11. DMR REDuction/OXidation (REDOX) of Product

\begin{tabular}{|c|c|c|c|}
\hline & Run 1 & Run 2 & Run 3 \\
\hline REDOX- Fe+2/Fe(tot) & 0.58 & 0.98 & 1 \\
\hline REDOX - Fe+2/Fe+3 & 1.4 & Fully reduced & Fully reduced \\
\hline
\end{tabular}

The REDOX or $\mathrm{Fe}^{2+} / \mathrm{Fe}_{\text {total }}$ ratio was determined for the BSR DMR products to determine if a reducing pyrolysis environment was maintained in the BSR DMR. Note that a ratio close to 0 is highly oxidizing and a ratio of 1 is highly reducing. The desired REDOX is $>0.5$. The REDOX analyses showed the reactions occurred in a reducing atmosphere as was required for pyrolysis. 
Table 12. DMR Anions in $\mathrm{mg} / \mathrm{L}$ of Dissolved Product

\begin{tabular}{|l|c|c|c|}
\hline \multicolumn{1}{|c|}{ Soluble } & Run 1 & Run 2 & Run 3 \\
\hline FLUORIDE & $<2.5$ & $<2.5$ & $<2.5$ \\
\hline FORMATE & $<2.5$ & $<2.5$ & $<2.5$ \\
\hline CHLORIDE & 32 & 25 & 21 \\
\hline NITRITE & $<2.5$ & $<2.5$ & $<2.5$ \\
\hline NITRATE & $<2.5$ & $<2.5$ & 14 \\
\hline PHOSPHATE & 33 & 29 & 38 \\
\hline SULFATE & 80 & 55 & 18 \\
\hline OXALATE & $<2.5$ & $<2.5$ & $<2.5$ \\
\hline BROMIDE & $<2.5$ & $<2.5$ & \\
\hline
\end{tabular}

To determine the destruction of $\mathrm{NO}_{2}$ and $\mathrm{NO}_{3}, 4$ grams of DMR product were dissolved into 400 $\mathrm{ml}$ of DI water. Thus:

$\frac{2.5 \mathrm{mg}}{1000 \mathrm{ml}} \times \frac{400 \mathrm{ml}}{4 g_{-} \text {product }} \leq 0.25 \frac{\mathrm{mg}}{g_{-} \text {product }}$ of $\mathrm{NO}_{2}$ and of $\mathrm{NO}_{3}$ in the product based on lower detection limit in Table 12.

$70 g_{-}$product $\times \frac{0.25 \mathrm{mgNO}}{g_{-} \text {product }} \leq 17.5 \mathrm{mgNO}_{x}$

With $70 \mathrm{~g}$ product, $17.5 \mathrm{mg}$ of $\mathrm{NO}_{2}$ and of $\mathrm{NO}_{3}$ is the lower limit of the measurement.

The Tank $48 \mathrm{H}$ waste contained $14250 \mathrm{mg} / \mathrm{L}$ nitrate and $23750 \mathrm{mg} / \mathrm{L}$ nitrite as shown in Table 6. Each run fed $300 \mathrm{ml}$ of waste to the DMR. Thus:

$300 \mathrm{ml} \times \frac{14250 \mathrm{mgNO}_{3}}{1000 \mathrm{ml}}=4275 \mathrm{mgNO}_{3}$

$300 \mathrm{ml} \times \frac{23750 \mathrm{mgNO}_{2}}{1000 \mathrm{ml}}=7125 \mathrm{mgNO}_{2}$

Converting to \% destruction:

$\frac{4275-17.5}{4275} \times 100 \geq 99.6 \%$ destruction of nitrates (shown) and

$\frac{7125-17.5}{7125} \times 100 \geq 99.8 \%$ destruction of nitrites (shown).

The process met the criteria of showing greater than $99 \%$ destruction of $\mathrm{NO}_{2}$ and $\mathrm{NO}_{3}$. 
SRNS-STI-2008-00105

Revision 0, 9/25/08

Table 13. Soluble Cations from DMR Product vs Feed

\begin{tabular}{|c|c|c|c|c|}
\hline \multirow{yynn}{*yyn}{ Soluble ICP-ES } & $\begin{array}{c}\text { Run 1 } \\
\text { wt\% }\end{array}$ & $\begin{array}{c}\text { Run 2 } \\
\text { wt\% }\end{array}$ & $\begin{array}{c}\text { Run 3 } \\
\text { wt\% }\end{array}$ & $\begin{array}{c}\text { Feed } \\
\text { wt\% }\end{array}$ \\
\hline Al & 1.000 & 0.751 & 0.715 & 1.039 \\
\hline $\mathrm{B}$ & 0.561 & 0.392 & 0.417 & 0.447 \\
\hline $\mathrm{Ca}$ & 0.062 & 0.051 & 0.048 & 0.022 \\
\hline $\mathrm{Cr}$ & 0.021 & 0.003 & 0.008 & 0.036 \\
\hline $\mathrm{Fe}$ & 0.002 & 0.003 & 0.003 & 0.087 \\
\hline $\mathrm{K}$ & 1.180 & 0.926 & 0.851 & 2.661 \\
\hline $\mathrm{Mg}$ & 0.004 & 0.006 & 0.005 & 0.010 \\
\hline $\mathrm{Na}$ & 47.800 & 38.900 & 36.600 & 45.366 \\
\hline $\mathrm{P}$ & 0.139 & 0.111 & 0.110 & 0.067 \\
\hline $\mathrm{S}$ & 0.254 & 0.196 & 0.222 & 0.195 \\
\hline $\mathrm{Si}$ & 0.077 & 0.077 & 0.122 & 0.065 \\
\hline $\mathrm{Sr}$ & 0.004 & 0.005 & 0.003 & 0.005 \\
\hline
\end{tabular}

The soluble cations in the DMR products are present at similar ratios as they are in the starting Tank $48 \mathrm{H}$ slurry. Sodium is present in the range of 36 to $46 \mathrm{wt} \%$ and potassium and aluminum are present in the range of 0.7 to $1.1 \mathrm{wt} \%$. These are the main soluble cations present in the DMR products along with lower levels of $\mathrm{B}, \mathrm{Ca}, \mathrm{P}, \mathrm{S}$ and $\mathrm{Si}$. 
SRNS-STI-2008-00105

Revision 0, 9/25/08

Table 14. Validation Results ${ }^{4}$

\begin{tabular}{|c|c|c|c|c|}
\hline $\begin{array}{l}\text { Performance } \\
\text { Criteria }\end{array}$ & $\begin{array}{l}\text { BSR Results Converted to } \\
\text { Performance Criteria }\end{array}$ & $\begin{array}{l}\text { Validation } \\
\text { Criteria } \\
\text { Met }\end{array}$ & Analytic Methods & BSR Analytic Result \\
\hline $\begin{array}{c}\text { Show }>99 \% \text { removal } \\
\text { of feed phenylborates } \\
\text { (TPB) }\end{array}$ & $99.99 \%$ destruction of ТРВ & Yes & $\begin{array}{l}\text { HPLC Analyses on } \\
\text { feed sample \& } \\
\text { DMR Solid } \\
\text { Product } \\
\end{array}$ & $\begin{array}{c}\leq 0.35 \mathrm{mg} \text { TPB (detection limit) } \\
\text { in DMR solid product vs } 6300 \\
\text { mg TPB fed }\end{array}$ \\
\hline \multirow{5}{*}{$\begin{array}{l}\text { Show that product is } \\
\text { primarily carbonate }\end{array}$} & \multirow{5}{*}{$\begin{array}{l}\text { Product is primarily } \\
\text { carbonate. The silicates } \\
\text { and aluminosilicate are } \\
\text { minor constituents coming } \\
\text { from the coal ash. }\end{array}$} & \multirow{5}{*}{ Yes } & \multirow{5}{*}{$\begin{array}{l}\text { XRD on DMR } \\
\text { Solid Product }\end{array}$} & $\mathrm{Na}_{2} \mathrm{CO}_{3} \cdot \mathrm{H}_{2} \mathrm{O}$ \\
\hline & & & & $\mathrm{Na}_{2} \mathrm{CO}_{3}$ \\
\hline & & & & $\mathrm{Na}_{3} \mathrm{H}\left(\mathrm{CO}_{3}\right)_{2 \cdot} \cdot 2 \mathrm{H}_{2} \mathrm{O}$ \\
\hline & & & & $\mathrm{Na}_{8}\left(\mathrm{AlSiO}_{4}\right)_{6}(\mathrm{OH})_{2} \bullet 2 \mathrm{H}_{2} \mathrm{O}$ \\
\hline & & & & $\mathrm{Na}_{2} \mathrm{Al}_{2} \mathrm{SiO}_{6}$ \\
\hline $\begin{array}{l}\text { Verify reducing } \\
\text { environment } \\
\text { (pyrolysis) in DMR }\end{array}$ & $\begin{array}{l}\text { DMR reactions are pyrolitic } \\
\text { as evidenced by } \mathrm{H}_{2} \\
\text { generation monitored by } \\
\text { mass spectrometers during } \\
\text { the experiments and the } \\
\text { measured REDOX of the } \\
\text { solid product being }>0.5 \text {. }\end{array}$ & Yes & $\begin{array}{l}\text { REDOX on DMR } \\
\text { Solid Product }\end{array}$ & $\begin{array}{c}\text { In DMR solid product the } \\
\text { REDOX ratio } \\
\mathrm{Fe}^{2+} / \mathrm{Fe}_{\text {total }} \text { REDOX ranged from } \\
0.58 \text { to } 1 .\end{array}$ \\
\hline $\begin{array}{c}\text { Show }>99 \% \\
\text { destruction of feed } \\
\text { nitrates }\end{array}$ & $\begin{array}{c}\text { Destruction of the feed } \\
\text { nitrates and nitrites was } \\
>99 \% \text {. }\end{array}$ & Yes & $\begin{array}{l}\text { IC Anions/ICP-ES } \\
\text { cations on Soluble } \\
\text { Solid Product; } \\
\text { wt } \% \text { solids and IC } \\
\text { Anions of feed } \\
\text { slurry }\end{array}$ & $\begin{array}{l}<17.5 \mathrm{mg} \text { vs. } 4275 \mathrm{mg} \mathrm{NO}_{3} \text { fed } \\
<17.5 \mathrm{mg} \text { vs } 7125 \mathrm{mg} \mathrm{NO}_{2} \text { fed } \\
\text { (based on detection limits) }\end{array}$ \\
\hline \multirow{5}{*}{$\begin{array}{l}\text { Check if DMR product } \\
\text { has insoluble carbonate }\end{array}$} & \multirow{5}{*}{$\begin{array}{l}\text { There was no detectable } \\
\text { insoluble carbonates down } \\
\text { to the detection limit of } 2 \% \\
\text { for XRD analysis. }\end{array}$} & \multirow{5}{*}{ Yes } & \multirow{5}{*}{$\begin{array}{c}\text { XRD on } \\
\text { dissolved/filtered } \\
\text { insoluble solids } \\
\text { from DMR solid } \\
\text { product }\end{array}$} & $\mathrm{Na}_{8}\left(\mathrm{AlSiO}_{4}\right)_{6}(\mathrm{OH})_{2} \bullet 2 \mathrm{H}_{2} \mathrm{O}$ \\
\hline & & & & $\mathrm{Na}_{0.75} \mathrm{~K}_{0.24} \mathrm{Al}_{0.95} \mathrm{Fe}_{0.13} \mathrm{Si}_{0.77} \mathrm{O}_{4}$ \\
\hline & & & & $\mathrm{NaFeTiO}_{4}$ \\
\hline & & & & Muscovite aluminosilicate \\
\hline & & & & $\mathrm{SiO}_{2}$ \\
\hline $\begin{array}{c}\text { Offgas Measurement } \\
\text { of } \mathrm{H}_{2}, \mathrm{O}_{2}, \mathrm{~N}_{2}, \mathrm{CO}_{2}, \\
\text { Benzene }\end{array}$ & $\begin{array}{l}\text { The DMR and CRR offgas } \\
\text { had expected levels (*see } \\
\text { Table } 4 \text { and Table } 5 \text { ) of } \mathrm{H}_{2} \text {, } \\
\mathrm{O}_{2}, \mathrm{~N}_{2}, \mathrm{CO}_{2} \text {, and Benzene, } \\
\text { ie. the DMR offgas showed } \\
\text { evidence of } \mathrm{H}_{2} \text { and benzene } \\
\text { evolution while the CRR } \\
\text { values were equivalent to } \\
\text { zero. }\end{array}$ & Yes & $\begin{array}{l}\text { Online Monitor } \\
\text { Instrument Mass } \\
\text { Spectrometer } \\
\text { Series } 3000\end{array}$ & $\begin{array}{c}\text { DMR Offgas Average Ranges } \\
\text { 2.06-2.64 vol\% } \mathrm{H}_{2} \\
4.45-5.51 \text { vol } \% \mathrm{O}_{2} \\
40.1-45.4 \text { vol } \% \mathrm{~N}_{2} \\
32.8-48.2 \text { vol } \% \mathrm{CO}_{2} \\
\text { 0.04-0.09 vol\% Benzene } \\
\\
\text { CRR Offgas Averages: } \\
\text { 0.02-0.03 vol } \% \mathrm{H}_{2} \\
9.8-14.4 \text { vol } \% \mathrm{O}_{2} \\
58.4-62.7 \text { vol } \% \mathrm{~N}_{2} \\
14.7-21 \text { vol } \% \mathrm{CO}_{2} \\
0.00 \text { vol } \% \text { Benzene* }\end{array}$ \\
\hline
\end{tabular}


The Tank $48 \mathrm{H}$ radioactive runs in the BSR met all the validation results ${ }^{4}$ as shown in Table 14.

Though not associated with a validation requirement, the LWO customer requested analysis of the DMR products for mercury. Results showed no detectable mercury from the three runs with a detection limit of 0.497 micrograms of mercury per gram of solid DMR product. As expected, the steam stripped the mercury away from the product at high $\mathrm{pH}$ conditions. Though the feed sample results for HTF-E-05-021 ${ }^{6}$ showed no mercury because the method probably drove it off, 20.4 $\mathrm{mg} / \mathrm{L}$ mercury was measured in sample HTF-E- $04-049^{7}$ which also came from Tank $48 \mathrm{H}$.

\subsection{ANALYSIS OF CONDENSATES}

Table 15 shows the Volatile Organic Analyses (VOA) and the Semi-Volatile Organic Analyses (SVOA) of the off-gas condensates. VOA is the quantitative analysis of solids/liquids/gases for most organic compounds which boil $<=200^{\circ} \mathrm{C}$ and partition favorably into the gas phase. SVOA is the quantitative organics analysis for radioactive and non-radioactive samples containing high boiling analytes.

At the start of the 3 runs, there is about $100 \mathrm{ml}$ of process water in the DMR bubbler and $200 \mathrm{ml}$ of process water in the CRR bubbler. All steam that is condensed from the DMR and CRR condenses into the DMR bubbler and CRR bubbler respectively. As liquid accumulates in either bubbler, it reaches an overflow where it flows into a sealed collection container. At the end of each run, the DMR collection container and the CRR collection container are emptied, but the fluid left over in each bubbler remains for the beginning of the next run. So the expectation is that each run will have more organics in the DMR bubbler than the last. Since that was not the case, the sampling technique for the DMR bubbler data may have been an issue. Benzene and biphenyl were expected in the DMR bubbler due to the partial destruction of TPB.

The DMR dry ice condensers were in series and the first condenser was expected to have more benzene than the second as was the case. Though these condensers did remove benzene, they did not remove it all as can be seen in the off-gas data in Table 4.

The CRR destroys organics by design. The off-gas data in Table 5 confirmed the destruction of benzene, but Table 15 shows a large amount of benzene left the CRR in run 2 as well as some benzene in run 3 . This data contradicts itself since the run 2 benzene is much greater than the run 3 benzene $(7500>>4.3)$ and does not represent the process.

The DMR collection container typically ends up with about $650 \mathrm{ml}$ of aqueous per run while the CRR collection container ends up with about $350 \mathrm{ml}$ per run. 
SRNS-STI-2008-00105

Revision 0, 9/25/08

Table 15. Organic Analyses of Condensates

\begin{tabular}{|c|c|c|c|c|c|c|}
\hline VOA / SVOA & $\begin{array}{c}\text { Run } 1 \\
\text { VOA, } \mathbf{m g} / \mathrm{L}\end{array}$ & $\begin{array}{c}\text { Run } 1 \\
\text { SVOA, mg/L }\end{array}$ & $\begin{array}{c}\text { Run } 2 \\
\text { VoA, } \mathrm{mg} / \mathrm{L}\end{array}$ & $\begin{array}{c}\text { Run } 2 \\
\text { SVOA, mg/L }\end{array}$ & $\begin{array}{c}\text { Run } 3 \\
\text { VOA, } \mathrm{mg} / \mathrm{L}\end{array}$ & $\begin{array}{c}\text { Run } 3 \\
\text { SVOA, mg/L }\end{array}$ \\
\hline \multirow[t]{7}{*}{ DMR Bubbler } & Benzene $=50$. & Phenol $=28$. & Benzene $=60$. & no analytes detected & no analytes detected & Phenol $=100$ \\
\hline & Toluene $=5.7$ & Biphenyl = 18 . & & & & Benzonitrile $=7.6$ \\
\hline & & & & & & 2-methylphenol = 2.0 \\
\hline & & & & & & 4-methylphenol = 2.2 \\
\hline & & & & & & Acetophenone $=2.1$ \\
\hline & & & & & & Biphenyl = 17. \\
\hline & & & & & & Phthalates $=26$. \\
\hline \multirow[t]{2}{*}{ CRR Dry Ice Cond. } & no analytes detected & no analytes detected & Benzene $=130$. & no analytes detected & no analytes detected & Phthalates $=94$. \\
\hline & & & Biphenyl = 53 . & & & \\
\hline \multirow[t]{3}{*}{ CRR Bubbler } & no analytes detected & Phenol $=30$. & Benzene $=7500$. & Phenol $=48$. & Benzene $=4.3$ & no analytes detected \\
\hline & & Biphenyl = 16. & Toluene $=340$ & Biphenyl = 63. & & \\
\hline & & Benzonitrile $=4.1$ & & & & \\
\hline \multirow[t]{13}{*}{ DMR Dry Ice \#1 } & Benzene $=7300$. & Biphenyl = 500. & Benzene $=5100$. & Phenol $=8.8$ & Benzene $=2300$. & Benzaldehyde $=7.1$ \\
\hline & & Naphthalene $=140$. & & Benzonitrile $=5.8$ & & Benzonitrile $=2.3$ \\
\hline & & Xylenes $=46$. & & Hexanal $=5.4$ & & Napthalene $=33$. \\
\hline & & Benzonitrile $=35$. & & & & Biphenyl = 260 . \\
\hline & & o-Terphenyl = 29. & & & & Dibenzofuran $=5.8$ \\
\hline & & Benzofuran = 16. & & & & o-Terphenyl = 14 . \\
\hline & & Hexanal = 14 . & & & & $\mathrm{m}$-terphenyl $=6.1$ \\
\hline & & m-Terphenyl = 12 . & & & & p-Terphenyl $=6.9$ \\
\hline & & Ethylbenzene $=10$. & & & & \\
\hline & & Benzaldehyde $=9.9$ & & & & \\
\hline & & Dibenzofuran $=8.5$ & & & & \\
\hline & & 2-Methylbenzofuran $=8.0$ & & & & \\
\hline & & Methoxybenzene $=3.1$ & & & & \\
\hline \multirow[t]{19}{*}{ DMR Dry Ice \#2 } & Benzene $=360$. & Benzonitrile $=18$. & Benzene $=940$. & Benzonitrile $=12$. & Benzene $=1400$. & Biphenyl = 190 . \\
\hline & Biphenyl $=6.7$ & Phenol = 16. & Toluene $=190$. & Phenol = 12. & & Phthalates $=180$. \\
\hline & & Biphenyl $=6.8$ & Naphthalene $=110$. & Hexanal $=6.1$ & & Phenol $=33$. \\
\hline & & Acetophenone $=1.8$ & & Biphenyl $=6.0$ & & Napthalene $=32$. \\
\hline & & Benzofuran = 1.1 & & & & Benzonitrile $=15$. \\
\hline & & & & & & Hexanal = 14 . \\
\hline & & & & & & o-Terphenyl $=8.5$ \\
\hline & & & & & & Benzofuran $=8.0$ \\
\hline & & & & & & Dibenzofuran $=3.4$ \\
\hline & & & & & & Heptanal $=3.0$ \\
\hline & & & & & & $\mathrm{m}$-terphenyl $=3.0$ \\
\hline & & & & & & Ethylbenzene $=2.5$ \\
\hline & & & & & & p-Xylene $=2.3$ \\
\hline & & & & & & 2-Nonaone $=2.3$ \\
\hline & & & & & & Nonane $=1.9$ \\
\hline & & & & & & Decyl trifluoroacetate 1.9 \\
\hline & & & & & & Tridecane $=1.9$ \\
\hline & & & & & & 2-Phenylpyridine $=1.9$ \\
\hline & & & & & & 2 -Heptanone $=1.7$ \\
\hline
\end{tabular}


Table 16. Radioactivity Distribution of Feed to Product

\begin{tabular}{|r|c|c|c|c|}
\hline Run & $\begin{array}{c}\text { Feed } \\
\text { \% rad. }\end{array}$ & $\begin{array}{c}\text { DMR Bubbler } \\
\text { \% rad. }\end{array}$ & $\begin{array}{c}\text { CRR Bubbler } \\
\text { \% rad. }\end{array}$ & $\begin{array}{c}\text { Product } \\
\% \text { rad. }\end{array}$ \\
\hline 1 & 100 & 8.172 & 0.002 & 91.827 \\
\hline 2 & 100 & 4.633 & 0.015 & 95.352 \\
\hline 3 & 100 & 3.453 & 0.032 & 96.515 \\
\hline
\end{tabular}

The $\mathrm{d} / \mathrm{m} / \mathrm{ml}$ (disintegrations/minute/milliliter) of the DMR bubbler condensate and CRR bubbler condensate were measured for each run. The DMR bubbler holds $650 \mathrm{ml}$ per run and the CRR bubbler holds $350 \mathrm{ml}$ per run. The $\mathrm{d} / \mathrm{m} / \mathrm{ml}$ of the feed was analyzed in 2005 . $^{6}$ Each run used $300 \mathrm{ml}$ of feed. As shown in Table 16, the majority of the radioactivity ended up in the product (based on calculation). The calculations are shown in APPENDIX 2.

\subsection{OBSERVATION OF OFF-GAS}

Analysis of the off-gas was performed in real time and was shown in section 4.2 of this report. However, two species of gas that were not measured due to measurement difficulty were NO and $\mathrm{NO}_{2}$. Fortunately, $\mathrm{NO}_{2}$ is a strongly colored gas which appears yellowish-brown even at very low concentrations. During the simulant runs, close observation of the gases while holding white paper behind the off-gas line leaving the DMR revealed only clear off-gas indicating that all of the $\mathrm{NO}_{2}$ was destroyed. This same observation was made during the radioactive runs but may not be as accurate due to the poorer visibility in the cells. The $\mathrm{H}_{2}$ concentration leaving the DMR, i.e. excess hydrogen, was also a good indication that all the $\mathrm{NO}_{\mathrm{x}}$ was destroyed in the vapor phase. 
SRNS-STI-2008-00105

Revision 0, 9/25/08

\subsection{COMPARISON OF SIMULANT WASTE WITH ACTUAL WASTE}

Table 17. Simulant Characterization Data

\begin{tabular}{|c|c|c|c|}
\hline Tank 48H Simulant & & & \\
\hline Component & $(\mathrm{mg} / \mathrm{L})$ & Component & $(\mathrm{mg} / \mathrm{L})$ \\
\hline $\mathrm{Al}$ & 1918 & $\mathrm{Ru}$ & $<1$ \\
\hline $\mathrm{B}$ & 573 & $\mathrm{~S}$ & 122 \\
\hline $\mathrm{Ba}$ & 0.68 & $\mathrm{Si}$ & 116 \\
\hline $\mathrm{Ca}$ & 90.3 & Sn & 16.8 \\
\hline $\mathrm{Cd}$ & $<1$ & $\mathrm{Sr}$ & 16.6 \\
\hline $\mathrm{Ce}$ & 3.47 & $\mathrm{Ti}$ & 650 \\
\hline $\mathrm{Cr}$ & 37.1 & $\mathrm{Zn}$ & 4.84 \\
\hline $\mathrm{Cu}$ & 4.48 & $\mathrm{Zr}$ & $<1$ \\
\hline $\mathrm{Fe}$ & 144 & $\mathrm{~F}$ & $<92$ \\
\hline $\mathrm{K}$ & 2983 & $\mathrm{Cl}$ & 136 \\
\hline $\mathrm{La}$ & 1.06 & $\mathrm{NO}_{2}$ & 19877 \\
\hline $\mathrm{Mg}$ & 1.07 & $\mathrm{NO}_{3}$ & 11637 \\
\hline $\mathrm{Mn}$ & 30.5 & $\mathrm{SO}_{4}$ & 185 \\
\hline Mo & 7.33 & $\mathrm{PO}_{4}$ & 357 \\
\hline $\mathrm{Na}$ & 73182 & wt $\%$ Total solids & 17.45 \\
\hline $\mathrm{Ni}$ & 10.4 & wt $\%$ Insoluble solids & 1.68 \\
\hline $\mathrm{P}$ & 170 & wt $\%$ Soluble solids & 15.8 \\
\hline $\mathrm{Pb}$ & 17.9 & $\mathrm{pH}$ & 14 \\
\hline $\mathrm{Pd}$ & 2.11 & Density $(\mathrm{g} / \mathrm{mL})$ & 1.09 \\
\hline $\mathrm{Rh}$ & 6.68 & & \\
\hline
\end{tabular}

Table 4-8 and 4-9 from Ref.1.

Simulants of the Tank 48H slurries were obtained from excess feed from the 2006 pilot-scale testing from Hazen Research, Inc. (HRI) facility in Golden, CO. Table 17 shows the characterization data (obtained from Analysis Results Tables 4-8 and 4-9 from Ref.1) 
SRNS-STI-2008-00105

Revision 0, 9/25/08

Table 18. Tank 48H Simulant vs Actual Tank 48H Waste Comparison

\begin{tabular}{|c|c|c|c|c|}
\hline & Simulant & Actual & Simulant & Actual \\
\hline Component & $\mathrm{mg} / \mathrm{L}$ & $\mathrm{mg} / \mathrm{L}$ & Normalized & Normalized \\
\hline $\mathrm{Al}$ & 1918 & 2014 & 5.96 & 5.06 \\
\hline B & 573 & 867 & 1.78 & 2.18 \\
\hline $\mathrm{Ba}$ & 0.68 & 0 & 0.00 & 0.00 \\
\hline $\mathrm{Ca}$ & 90.3 & 43 & 0.28 & 0.11 \\
\hline $\mathrm{Cd}$ & $<1$ & 0 & 0.00 & 0.00 \\
\hline $\mathrm{Ce}$ & 3.47 & 5 & 0.01 & 0.01 \\
\hline $\mathrm{Cr}$ & 37.1 & 70 & 0.12 & 0.18 \\
\hline $\mathrm{Cu}$ & 4.48 & 4 & 0.01 & 0.01 \\
\hline $\mathrm{Fe}$ & 144 & 169 & 0.45 & 0.42 \\
\hline $\mathrm{K}$ & 2983 & 5155 & 9.27 & 12.96 \\
\hline $\mathrm{La}$ & 1.06 & $<0.032$ & 0.00 & 0.00 \\
\hline $\mathrm{Mg}$ & 1.07 & 19 & 0.00 & 0.05 \\
\hline $\mathrm{Mn}$ & 30.5 & 6 & 0.09 & 0.02 \\
\hline$\overline{\mathrm{Mo}}$ & 7.33 & $<0.053$ & 0.02 & 0.00 \\
\hline $\mathrm{Na}$ & 73182 & 87899 & 227.33 & 220.93 \\
\hline $\mathrm{Ni}$ & 10.4 & $<0.015$ & 0.03 & 0.00 \\
\hline $\mathrm{P}$ & 170 & 129 & 0.53 & 0.32 \\
\hline $\mathrm{Pb}$ & 17.9 & $<0.283$ & 0.06 & 0.00 \\
\hline $\mathrm{Pd}$ & 2.11 & & 0.01 & 0.00 \\
\hline $\mathrm{Rh}$ & 6.68 & & 0.02 & 0.00 \\
\hline $\mathrm{S}$ & 122 & 378 & 0.38 & 0.95 \\
\hline $\mathrm{Si}$ & 116 & 125 & 0.36 & 0.31 \\
\hline $\mathrm{Sn}$ & 16.8 & $<0.11$ & 0.05 & 0.00 \\
\hline$\overline{\mathrm{Sr}}$ & 16.6 & 9 & 0.05 & 0.02 \\
\hline $\mathrm{Ti}$ & 650 & 826 & 2.02 & 2.08 \\
\hline $\mathrm{U}$ & & 7 & 0.00 & 0.02 \\
\hline $\mathrm{Zn}$ & 4.84 & 5 & 0.02 & 0.01 \\
\hline $\mathrm{Zr}$ & $<1$ & 1.47 & 0.00 & 0.00 \\
\hline $\mathrm{F}$ & $<92$ & 14 & 0.00 & 0.04 \\
\hline $\mathrm{Cl}$ & 136 & 172 & 0.42 & 0.43 \\
\hline $\mathrm{NO} 2$ & 19877 & 23750 & 61.75 & 59.70 \\
\hline NO3 & 11637 & 14250 & 36.15 & 35.82 \\
\hline $\mathrm{SO} 4$ & 185 & 323 & 0.57 & 0.81 \\
\hline $\mathrm{PO} 4$ & 357 & 428 & 1.11 & 1.08 \\
\hline $\mathrm{wt} \%$ Total solids & 17.45 & 20.19 & & \\
\hline $\mathrm{wt} \%$ Insoluble solids & 1.68 & 3.05 & & \\
\hline wt $\%$ Soluble solids & 15.8 & 17.14 & & \\
\hline $\mathrm{pH}$ & 14 & 14 & & \\
\hline Density $(\mathrm{g} / \mathrm{mL})$ & 1.09 & 1.14 & & \\
\hline
\end{tabular}

Data from Table 6, "Radioactive Tank 48H Data of HTF-E-05-021 Slurry Sample" and from Table 17, "Simulant Characterization Data", were combined into Table 18. By normalizing the component data it becomes clear that both liquids contain nearly the same ratios of the major components $\mathrm{Al}, \mathrm{B}, \mathrm{K}, \mathrm{Na}, \mathrm{Ti}, \mathrm{NO}_{2}, \mathrm{NO}_{3}$, and $\mathrm{PO}_{4}$. The solids, $\mathrm{pH}$, and density data also showed fairly good agreement. The detailed report on the simulant development is SRNL-LWP-2004$0042^{8}$ and a detailed report of the simulant validation is WSRC-LWP-2004-00009 ${ }^{9}$. 
SRNS-STI-2008-00105

Revision 0, 9/25/08

\subsection{COMPARISON OF DMR PRODUCTS AND KEY PROCESS CONDITIONS}

Table 19. FBSR Simulant vs BSR Simulant vs BSR Tk48H Waste Comparison

\begin{tabular}{|c|c|c|c|}
\hline $\begin{array}{l}\text { Performance } \\
\text { Criteria }\end{array}$ & FBSR Simulant $^{1}$ & BSR Simulant $^{10}$ & BSR Actual Tk48H \\
\hline $\begin{array}{c}\text { Show }>99 \% \text { removal } \\
\text { of feed phenylborates } \\
\text { (TPB) }\end{array}$ & $99.9 \%$ destruction of TPB & $99.9 \%$ destruction of TPB & $99.99 \%$ destruction of ТРВ \\
\hline \multirow{6}{*}{$\begin{array}{l}\text { Show that product is } \\
\text { primarily carbonate }\end{array}$} & $\mathrm{Na}_{2} \mathrm{CO}_{3} \cdot \mathrm{H}_{2} \mathrm{O}$ & $\mathrm{Na}_{2} \mathrm{CO}_{3} \cdot \mathrm{H}_{2} \mathrm{O}$ & $\mathrm{Na}_{2} \mathrm{CO}_{3} \cdot \mathrm{H}_{2} \mathrm{O}$ \\
\hline & $\mathrm{Na}_{2} \mathrm{CO}_{3}$ & $\mathrm{Na}_{2} \mathrm{CO}_{3}$ & $\mathrm{Na}_{2} \mathrm{CO}_{3}$ \\
\hline & $\mathrm{Na}_{3} \mathrm{H}\left(\mathrm{CO}_{3}\right)_{2} \cdot 2 \mathrm{H}_{2} \mathrm{O}$ & $\mathrm{Na}_{3} \mathrm{H}\left(\mathrm{CO}_{3}\right)_{2} \cdot 2 \mathrm{H}_{2} \mathrm{O}$ & $\mathrm{Na}_{3} \mathrm{H}\left(\mathrm{CO}_{3}\right)_{2} \cdot 2 \mathrm{H}_{2} \mathrm{O}$ \\
\hline & Nepheline & $\mathrm{Na}_{2} \mathrm{Al}_{2} \mathrm{SiO}_{6}$ & $\mathrm{Na}_{8}\left(\mathrm{AlSiO}_{4}\right)_{6}(\mathrm{OH})_{2} \bullet 2 \mathrm{H}_{2} \mathrm{O}$ \\
\hline & Cristobalite & Nepheline & \multirow[t]{2}{*}{$\mathrm{Na}_{2} \mathrm{Al}_{2} \mathrm{SiO}_{6}$} \\
\hline & & Cristobalite & \\
\hline $\begin{array}{c}\text { Verify reducing } \\
\text { environment } \\
\text { (pyrolysis) in DMR }\end{array}$ & $\begin{array}{l}\mathrm{Fe}^{2+} / \mathrm{Fe}_{\text {total }} \text { of around } 0.60 \\
\text { for DMR product. }\end{array}$ & $\begin{array}{c}\mathrm{Fe}^{2+} / \mathrm{Fe}_{\text {total }} \mathrm{REDOX} \text { was } 1 \text { for } \\
\text { DMR products. } *\end{array}$ & $\begin{array}{c}\mathrm{Fe}^{2+} / \mathrm{Fe}_{\text {total }} \mathrm{REDOX} \text { ranged } \\
\text { from } 0.58 \text { to } 1 \text { for DMR } \\
\text { product. }\end{array}$ \\
\hline $\begin{array}{c}\text { Show }>99 \% \\
\text { destruction of feed } \\
\text { nitrates }\end{array}$ & $\begin{array}{l}99.9 \% \text { Destruction of the } \\
\text { Feed Nitrates and nitrites }\end{array}$ & $\begin{array}{l}99.9 \% \text { Destruction of the Feed } \\
\text { Nitrates and nitrites }\end{array}$ & $\begin{array}{l}>99.6 \% \text { destruction of } \mathrm{NO}_{3} \\
>99.8 \% \text { destruction of } \mathrm{NO}_{2}\end{array}$ \\
\hline \multirow{6}{*}{$\begin{array}{c}\text { Check if DMR } \\
\text { product has insoluble } \\
\text { carbonate }\end{array}$} & Nepheline & Nepheline* & $\mathrm{Na} \mathrm{SiAl}$ oxide hydrate \\
\hline & $\mathrm{NaFeTiO} 4$ & $\mathrm{Na} 8(\mathrm{AlSiO} 4) 6(\mathrm{NO} 3) 2$ & Hydrosodalite \\
\hline & Quartz & NaFeTiO4 & nepheline \\
\hline & \multirow[b]{3}{*}{$\begin{array}{l}\text { No insoluble carbonate } \\
\text { detected. }\end{array}$} & Quartz & $\mathrm{NaFeTiO4}$ \\
\hline & & $\mathrm{ZrO} 2$ & Muscovite - 3T \\
\hline & & $\begin{array}{c}\text { No insoluble carbonate } \\
\text { detected. }\end{array}$ & \begin{tabular}{|c|} 
Quartz \\
No insoluble carbonate \\
detected.
\end{tabular} \\
\hline \multirow{2}{*}{$\begin{array}{l}\text { Offgas Measurement } \\
\text { of } \mathrm{H}_{2}, \mathrm{O}_{2}, \mathrm{~N}_{2}, \mathrm{CO}_{2} \\
\text { Benzene }\end{array}$} & $\begin{array}{c}\text { Average DMR offgas on } \\
\text { dry basis: } \\
1.1-2.5 \text { vol } \% \mathrm{H}_{2} \\
0.07-3.54 \mathrm{vol} \% \mathrm{O}_{2} \\
22.8-45.1 \text { vol } \% \mathrm{CO}_{2} \\
0.5-1.7 \text { vol } \% \text { Benzene }\end{array}$ & $\begin{array}{c}\text { Average DMR offgas on dry } \\
\text { basis: } \\
1.76-1.90 \text { vol } \% \mathrm{H}_{2} \\
0.38-3.96 \text { vol } \% \mathrm{O}_{2} \\
47.8-61.2 \mathrm{vol} \% \mathrm{~N}_{2} \\
45.7-51.9 \text { vol } \% \mathrm{CO}_{2} \\
0.04 \text { vol } \% \text { Benzene }\end{array}$ & $\begin{array}{c}\text { Average DMR offgas on dry } \\
\text { basis: } \\
2.06-2.64 \text { vol } \% \mathrm{H}_{2} \\
4.45-5.51 \text { vol } \% \mathrm{O}_{2} \\
40.1-45.4 \text { vol } \% \mathrm{~N}_{2} \\
32.8-48.2 \text { vol } \% \mathrm{CO}_{2} \\
0.04-0.09 \text { vol } \% \text { Benzene }\end{array}$ \\
\hline & $\begin{array}{c}\text { CRR Offgas Averages: } \\
\text { 10.1-11.6 vol\% } \mathrm{O}_{2} \\
15.7-21.6 \text { vol } \% \mathrm{CO}_{2} \\
0.00-2.3 \text { ppm } \mathrm{THC}\end{array}$ & $\begin{array}{c}\text { CRR Offgas Averages: } \\
\text { 0.05 vol } \% \mathrm{H}_{2} \\
3.43-11.7 \text { vol } \% \mathrm{O}_{2} \\
60.2-70.4 \text { vol } \% \mathrm{~N}_{2} \\
21.0-22.4 \text { vol } \% \mathrm{CO}_{2} \\
0.00 \text { vol } \% \text { Benzene* }\end{array}$ & $\begin{array}{c}\text { CRR Offgas Averages: } \\
\text { 0.02-0.03 vol } \% \mathrm{H}_{2} \\
9.8-14.4 \text { vol } \% \mathrm{O}_{2} \\
58.4-62.7 \text { vol } \% \mathrm{~N}_{2} \\
14.7-21 \text { vol } \% \mathrm{CO}_{2} \\
0.00 \text { vol } \% \text { Benzene* }\end{array}$ \\
\hline
\end{tabular}

FBSR Data taken from Table 4-8 in the Hazen Report ${ }^{1}$.

BSR Simulant data taken from SRNL-PSE-2008-00162 ${ }^{10}$.

*BSR simulant data from last two runs only.

Table 19 shows that both the ESTD FBSR and BSR successfully operated at the right temperatures with superheated steam and reducing conditions to destroy $>99 \%$ of the TPB, 
destroy $>99 \%$ of the nitrates and nitrites, and produce a primarily carbonate product. Insoluble species were found in the product from all tests, however no insoluble carbonates were detected using XRD which has a detection sensitivity down to $\sim 2 \mathrm{wt} \%$. These insoluble species are thought to form from the Erwin coal impurities and/or $\mathrm{Si}$ and $\mathrm{Al}$ species in the waste except for the $\mathrm{NaFeTiO}_{4}$ and $\mathrm{ZrO}_{2}$. The $\mathrm{NaFeTiO}_{4}$ was formed from the monosodium titanate and sludge impurities found in the waste and simulant. The $\mathrm{ZrO}_{2}$ can be attributed to the bed material used in the BSR.

Table 19 also shows that the products formed from running the simulant are very nearly the same as the products formed from running the actual Tank $48 \mathrm{H}$ waste.

\subsection{CONCLUSIONS}

The conclusions from the BSR study and comparison to the ESTD FBSR are the following:

A Bench-scale Steam Reforming (BSR) unit was successfully designed and built that:

- Emulated the chemistry of the Hazen ESTD FBSR Denitration Mineralization Reformer (DMR) and Carbon Reduction Reformer (CRR) known collectively as the dual reformer flowsheet.

- Measured and controlled the off-gas stream.

- Processed real (radioactive) Tank 48H waste.

- Met the standards and specifications for radiological testing in the Savannah River National Laboratory (SRNL) Shielded Cells Facility (SCF).

Three runs with radioactive Tank $48 \mathrm{H}$ material were performed.

- The TPB was destroyed to $>99 \%$ for all radioactive Bench-scale tests.

- The feed nitrate/nitrite was destroyed to $>99 \%$ for all radioactive BSR tests the same as the ESTD FBSR.

- The radioactive Tank 48H DMR product was primarily made up of soluble carbonates. The three most abundant species were thermonatrite, $\left[\mathrm{Na}_{2} \mathrm{CO}_{3} \cdot \mathrm{H}_{2} \mathrm{O}\right.$ ], sodium carbonate, [ $\mathrm{Na}_{2} \mathrm{CO}_{3}$ ], and trona, $\left[\mathrm{Na}_{3} \mathrm{H}\left(\mathrm{CO}_{3}\right)_{2} \cdot 2 \mathrm{H}_{2} \mathrm{O}\right]$ the same as the ESTD FBSR.

Insoluble solids analyzed by X-Ray Diffraction (XRD) did not detect insoluble carbonate species. However, they still may be present at levels below $2 \mathrm{wt} \%$, the sensitivity of the XRD methodology. Insoluble solids XRD characterization indicated that various $\mathrm{Fe} / \mathrm{Ni} / \mathrm{Cr} / \mathrm{Mn}$ phases are present. These crystalline phases are associated with the insoluble sludge components of Tank $48 \mathrm{H}$ slurry and impurities in the Erwin coal ash. The percent insoluble solids in the products were 4 to $11 \mathrm{wt} \%$ for the radioactive runs.

- The $\mathrm{Fe}^{+2} / \mathrm{Fe}_{\text {total }}$ REDOX measurements ranged from 0.58 to 1 for the three radioactive Benchscale tests. REDOX measurements $>0.5$ showed a reducing atmosphere was maintained in the DMR indicating that pyrolysis was occurring.. 
Greater than $90 \%$ of the radioactivity was captured in the product for all three runs.

- The collective results from the FBSR simulant tests and the BSR simulant tests indicate that the same chemistry occurs in the two reactors.

The collective results from the BSR simulant runs and the BSR radioactive waste runs indicates that the same chemistry occurs in the simulant as in the real waste.

\subsection{RECOMMENDATIONS}

Determine the source of the toluene and naphthalene found in the DMR bubbler and dry ice condenser samples.

\subsection{QUALITY ASSURANCE \& SAFETY}

All the data reported in this study were developed under the quality assurance given in the Technical Task and Quality Assurance Plan SRNL-PSE-2007-00022, Rev. $1^{3}$. The research program and task plan were developed to address the Technical Task Request SP-TTR-200600006 , Rev. 1, Mar. 12, 2007. ${ }^{2}$ The data are recorded in laboratory notebook WSRC-NB-2007$00175 .^{5}$

The Hazards Analysis Package ${ }^{11}$ (HAP) which details all the risks and mitigations was saved as SRNL-PSE-2008-00153. Since the $\mathrm{H}_{2}$ gas generation from steam reforming exceeded the past limit in the 773-A Design Safety Analysis (DSA), a Consolidated Hazard Analysis Package ${ }^{12}$ (CHAP) was written as WSRC-TR-2007-00457, Rev. 3 to address this issue. A change was made in the $\mathrm{H}_{2}$ gas generation limit, however, this change did not affect the ultimate safety limit of ensuring that the concentration of flammable gases in the cell remain less than $25 \%$ of the Lower Flammability Limit (LFL). 
SRNS-STI-2008-00105

Revision 0, 9/25/08

\section{APPENDIX 1. XRD GRAPHS OF DMR PRODUCTS}


SRNS-STI-2008-00105

Revision 0, 9/25/08

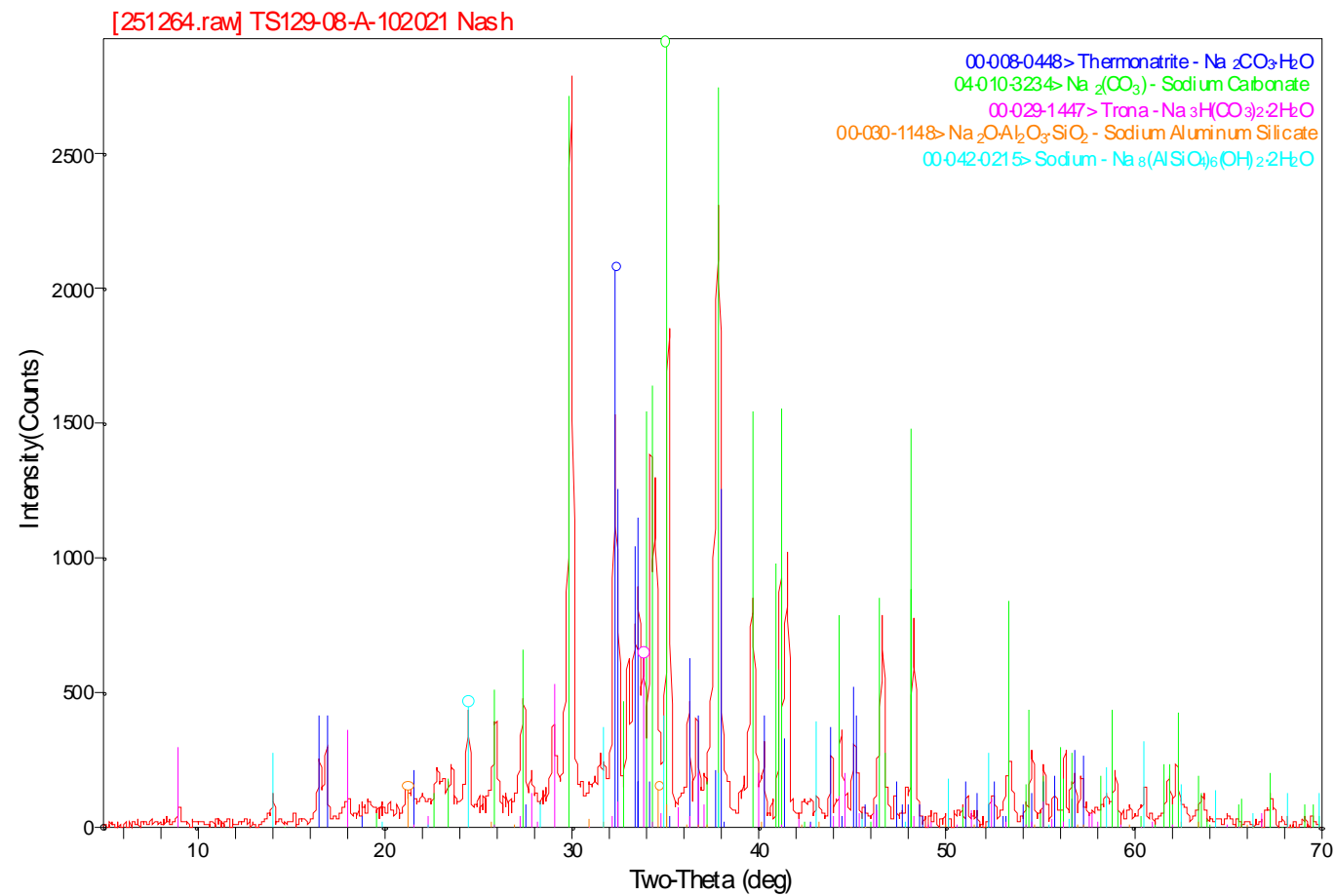

Figure A-1. Run 1 Bottom Product XRD

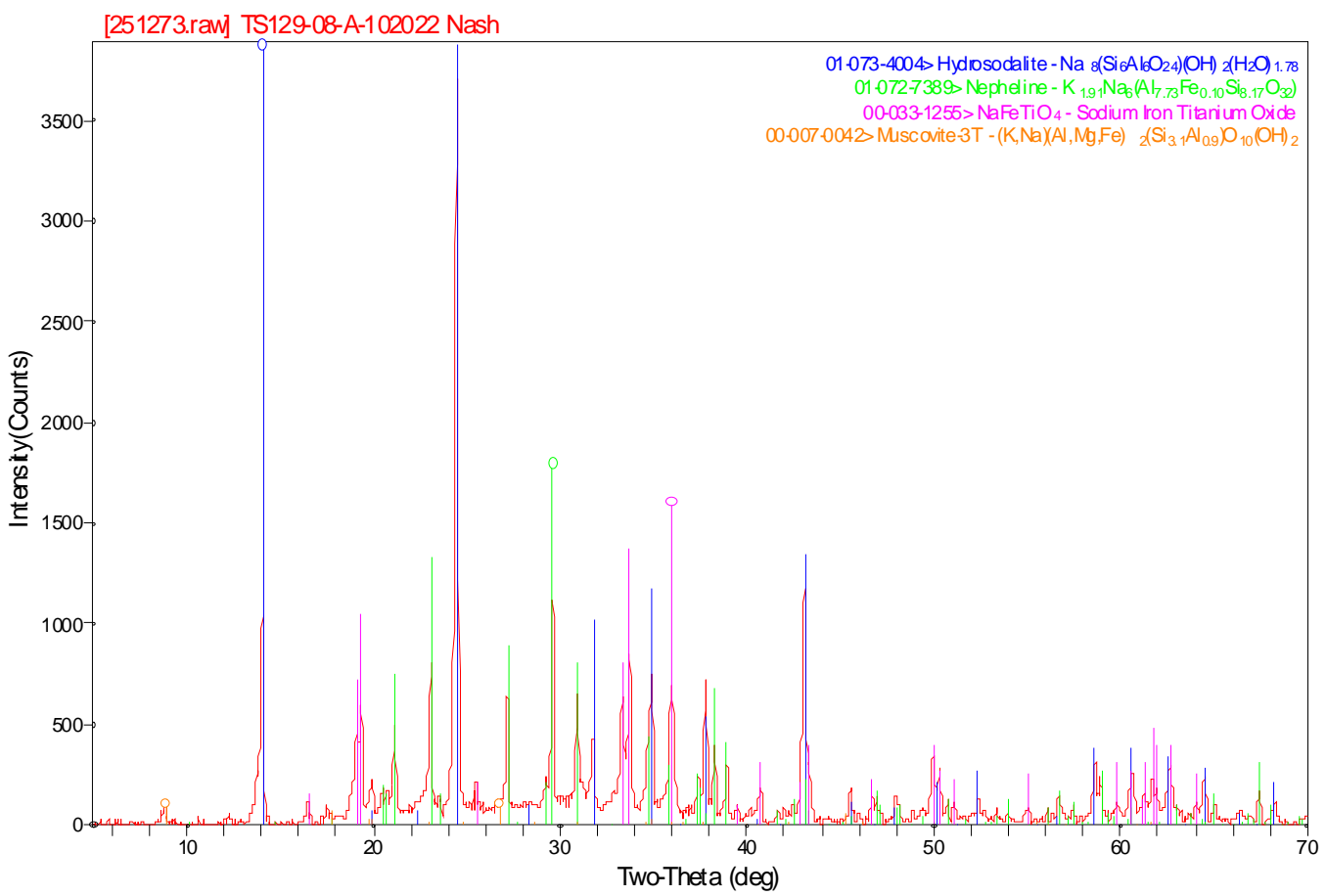

Figure A-2. Run 1 Bottom Insoluble Solids XRD 
SRNS-STI-2008-00105

Revision 0, 9/25/08

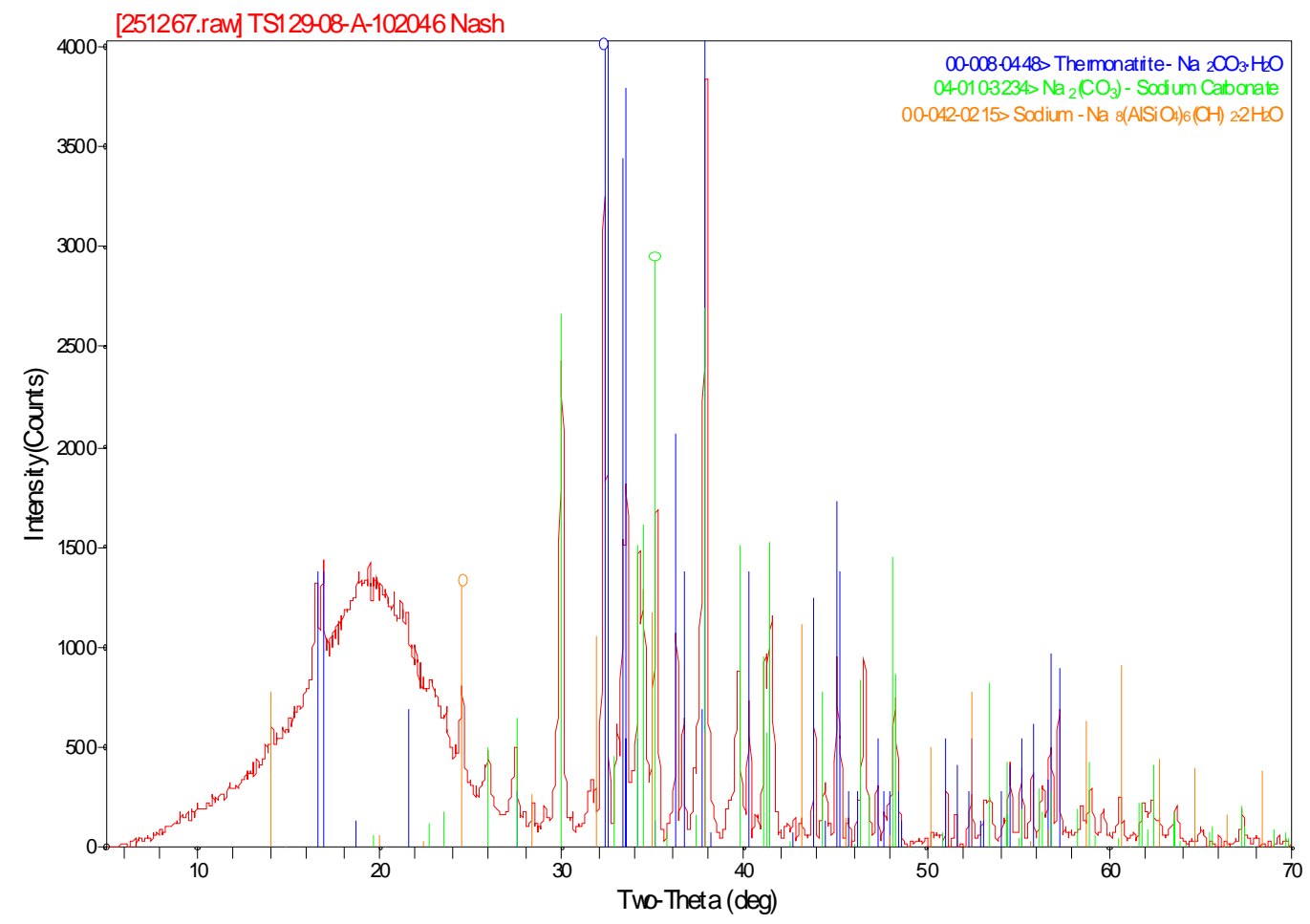

Figure A-3. Run 2 Bottom Product XRD

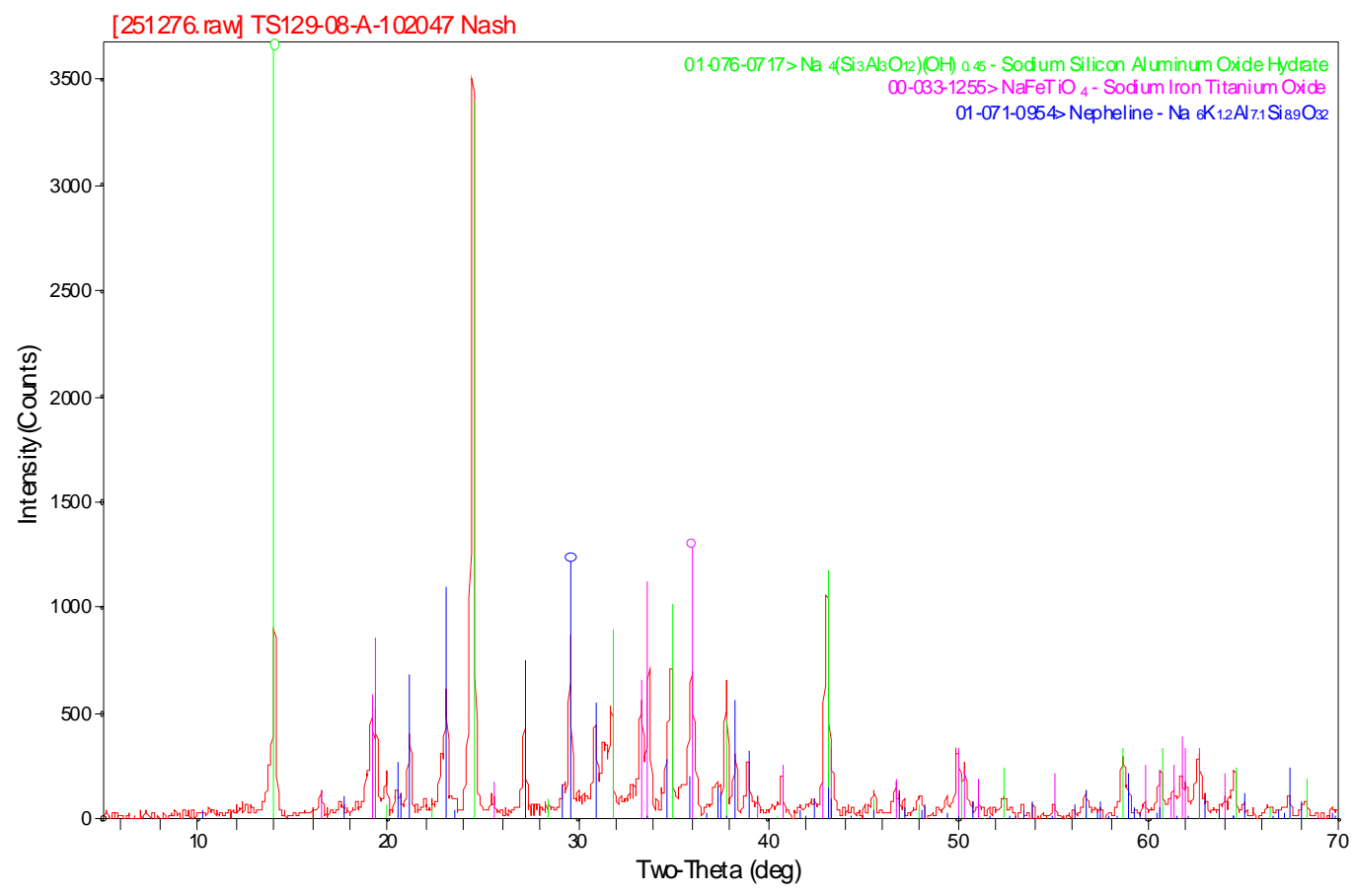

Figure A-4. Run 2 Bottom Insoluble Solids XRD 
SRNS-STI-2008-00105

Revision 0, 9/25/08

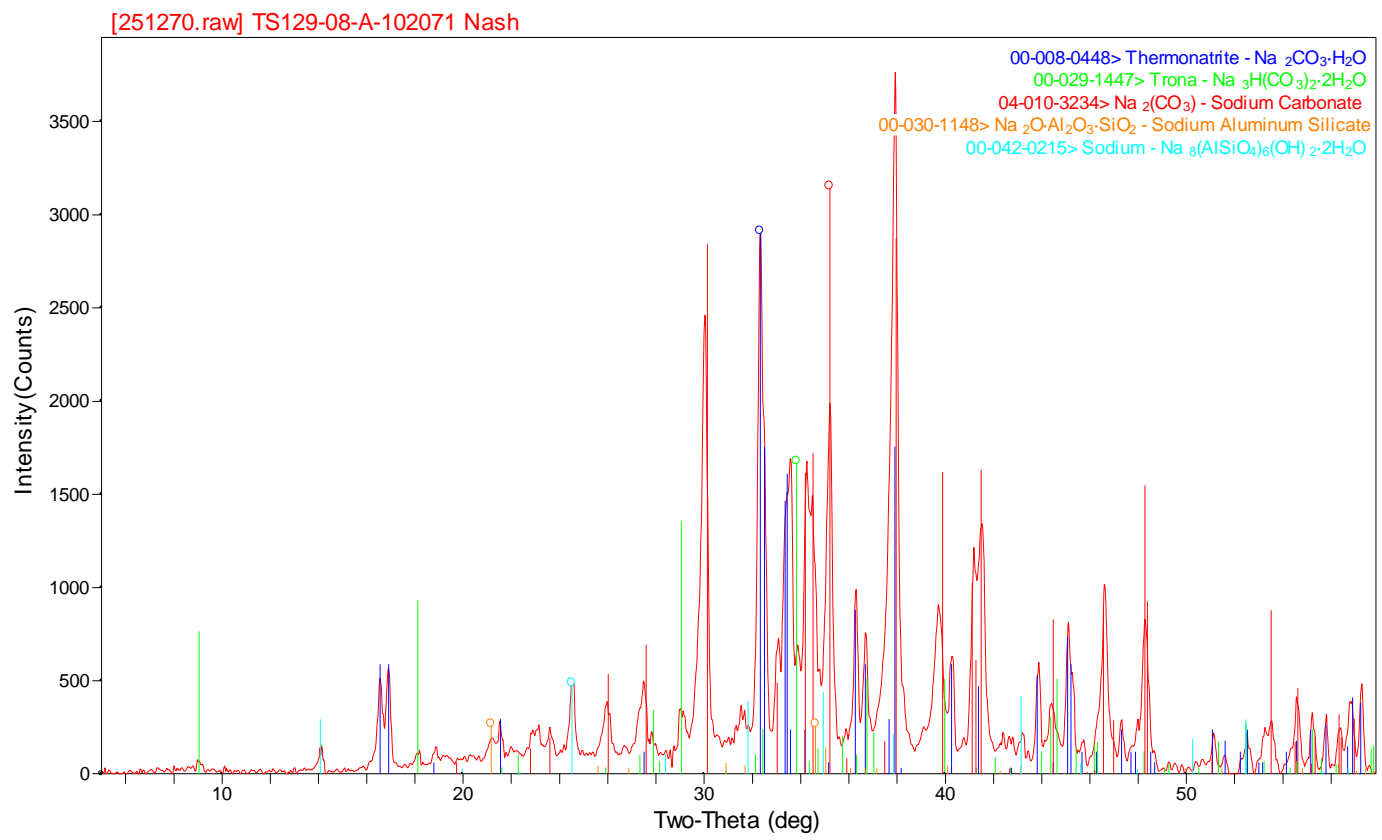

Figure A-5. Run 3 Bottom Product XRD

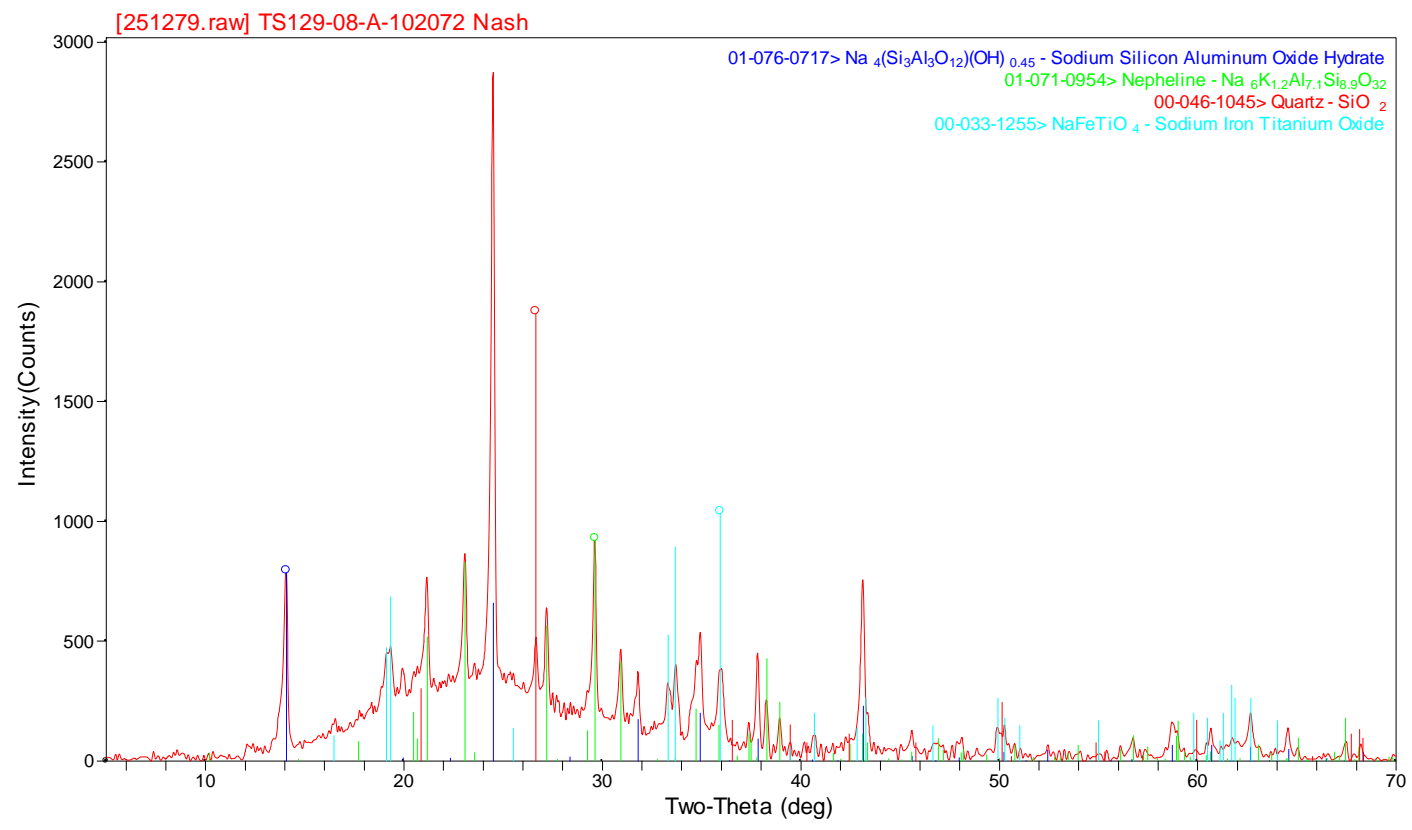

Figure A-6. Run 3 Bottom Insoluble Solids XRD 


\section{APPENDIX 2. Calculation of Radioactive Distribution}

\begin{tabular}{|c|c|c|c|c|c|c|c|c|c|c|c|c|c|}
\hline Run & $\begin{array}{c}\text { Feed } \\
\mathrm{ml}\end{array}$ & $\begin{array}{l}\text { Feed } \\
\mathrm{d} / \mathrm{m} / \mathrm{ml}\end{array}$ & $\begin{array}{l}\text { Feed } \\
d / m\end{array}$ & $\begin{array}{l}\text { percentage } \\
\text { rad. }\end{array}$ & $\begin{array}{c}\text { DMR Bubbler } \\
\mathrm{ml}\end{array}$ & \begin{tabular}{|c|} 
DMR Bubbler \\
$\mathrm{d} / \mathrm{m} / \mathrm{ml}$
\end{tabular} & $\begin{array}{c}\text { DMR Bubbler } \\
\mathrm{d} / \mathrm{m}\end{array}$ & $\begin{array}{l}\text { percentage } \\
\text { rad. }\end{array}$ & \begin{tabular}{|c|}
$\begin{array}{c}\text { CRR Bubbler } \\
\mathrm{ml}\end{array}$ \\
\end{tabular} & \begin{tabular}{|c|}
$\begin{array}{c}\text { CRR Bubbler } \\
\mathrm{d} / \mathrm{m} / \mathrm{ml}\end{array}$ \\
\end{tabular} & $\begin{array}{c}\text { CRR Bubbler } \\
\mathrm{d} / \mathrm{m}\end{array}$ & $\begin{array}{l}\text { precentage } \\
\text { rad. }\end{array}$ & $\begin{array}{l}\text { Product } \\
\text { Percent }\end{array}$ \\
\hline 1 & 300 & $7.53 \mathrm{E}+08$ & $2.26 \mathrm{E}+11$ & 100 & 650 & $2.84 \mathrm{E}+07$ & $1.85 \mathrm{E}+10$ & 8.17 & 350 & $1.11 \mathrm{E}+04$ & $3.89 \mathrm{E}+06$ & 0.00 & 91.83 \\
\hline 2 & 300 & $7.53 \mathrm{E}+08$ & $2.26 \mathrm{E}+11$ & 100 & 650 & $1.61 \mathrm{E}+07$ & $1.05 \mathrm{E}+10$ & 4.63 & 350 & $9.63 \mathrm{E}+04$ & $3.37 \mathrm{E}+07$ & 0.01 & 95.35 \\
\hline 3 & 300 & $7.53 \mathrm{E}+08$ & $2.26 \mathrm{E}+11$ & 100 & 650 & $1.20 \mathrm{E}+07$ & $7.80 \mathrm{E}+09$ & 3.45 & 350 & $2.06 \mathrm{E}+05$ & $7.21 \mathrm{E}+07$ & 0.03 & 96.52 \\
\hline
\end{tabular}

bubbler_d $/ m=$ bubbler_ml $\times$ bubbler_d $/ \mathrm{m} / \mathrm{ml}$

bubbler_rad $\%=\frac{\text { bubbler_d } d / m}{\text { feed_d } / m} \times 100$ 
SRNS-STI-2008-00105

Revision 0, 9/25/08

\subsection{REFERENCES}

${ }^{1}$ Tank 48H Test Report, "Pilot Plant Reporting for Treating Tank 48H Simulants Carbonate Flowsheet”, Doc. No. 28927-WEC-RPT-00001, Rev. 2, Prepared for WSRC by THOR Treatment Technologies, LLC and Washington Group International, May 2007.

${ }^{2}$ S. C. Shah, Technical Task Request, "FBSR Bench Scale Radioactive Testing”, SP-TTR-2006-00006, Rev. 2, Dec. 14, 2007.

${ }^{3}$ P. R. Burket, Task Technical \& QA Plan, "T48H Treatment Project - FBSR Bench Scale Radioactive waste", SRNL-PSE-2007-00022, Rev. 1, Jan. 15, 2008.

${ }^{4}$ W. E. Daniel, P. R. Burket, C. A. Nash, "Bench Scale Steam Reforming Accelerated Phase 2 Tank 48H Real Waste Testing Validation Plan”, SRNL-PSE-2008-00156, Jul., 10, 2008.

${ }^{5}$ P. R. Burket, “Tank 48H Steam Reforming Notebook”, WSRC-NB-2007-00175.

${ }^{6}$ F. F. Fondeur, D. P. Lambert and S. D. Fink, “Analysis of Tank 48H Sample - HTF-E-05-021", WSRC-TR-200500358, Rev.0, Oct. 3, 2005.

${ }^{7}$ Lambert, D.P., Analysis of Tank 48H Samples HTF-E-04-049 and HTF-E-04-050", WSRC-TR-2004-00514, rev. 1, May, 2005.

${ }^{8}$ Lambert, D.P., Tank 48H Simulant Recipe Development and Documentation, SRT-LWP-2004-00042, Revision 1, June 2004.

${ }^{9}$ Lambert, D.P. Tank 48H Simulant Validation, SRNL-LWP-2004-00009, 2004

${ }^{10}$ W. E. Daniel, P. R. Burket, C. A. Nash, "Bench Scale Steam Reforming Accelerated Phase 1 Simulant Testing Validation Results", SRNL-PSE-2008-00162, August, 2008.

${ }^{11}$ W. E. Daniel, "HAP for Tank 48H Benchtop Steam Reformer Demonstration within SRNL Shielded Cells", SRNL-PSE-2008-0-0153, July 17, 2008.

${ }^{12}$ D. M. Ferrara, "Savannah River National Laboratory Tank 48H Benchtop Steam Reformer Hazard Analysis", Rev. 3, July, 2008. 
Distribution:

J. C. Griffin, 773-A

A. B. Barnes, 999-W

S. D. Burke, 766-H

S. C. Shah, 766-H

C. L. Atseff, 703-H

C. G. Lampley, 766-H

C.M. Jantzen, 773-A

M. R. Williams, 786-5A

C. A. Nash, 773-42A

C. L. Crawford, 773-42A

W. E. Daniel, 999-W

P. R. Burket, 773-42A 